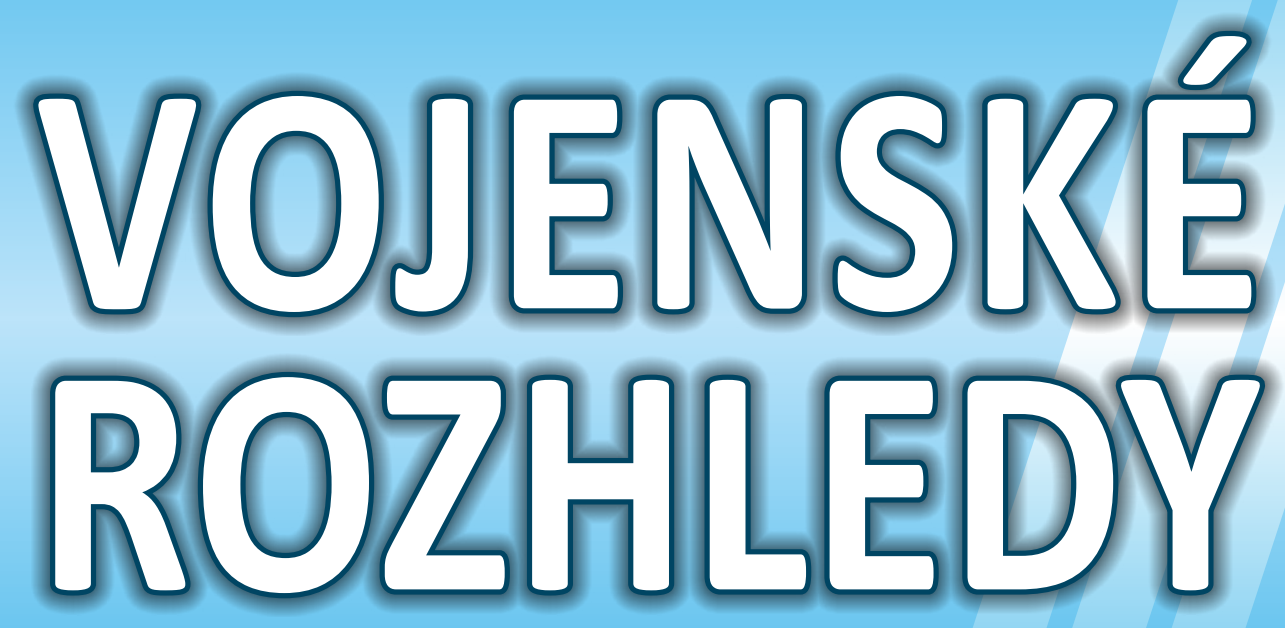

Czesh Milijitary Review
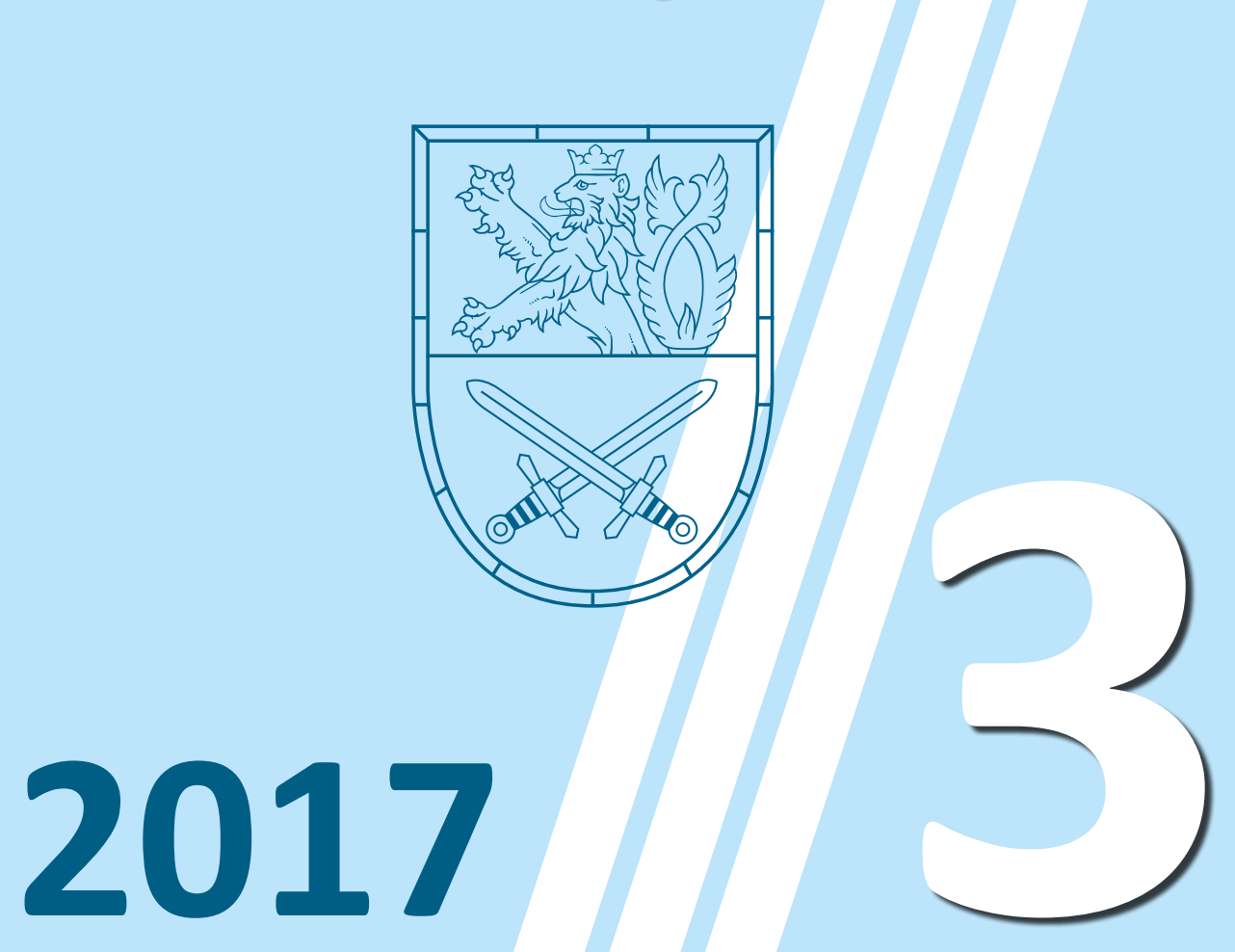


\section{VOJENSKOTEORETICKÝ ČASOPIS}
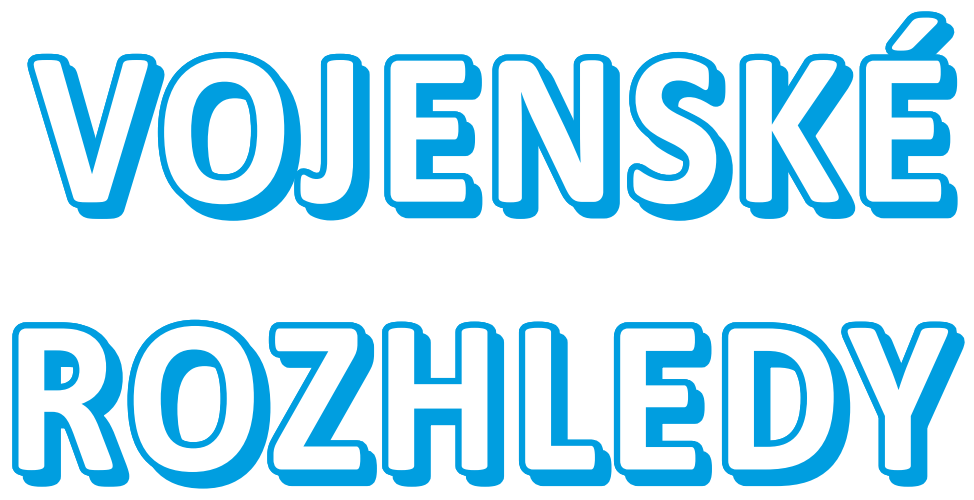

ROČNÍK 26 (58) 



\section{Vliv Ruska na dynamiku konfliktu v Náhorním Karabachu}

\section{Russia's Influence on the Conflict Dynamics in Nagorno Karabakh}

Pavlína Bláhová

Abstrakt: Zamrzlý konflikt v Náhorním Karabachu je po více než dvě dekády jednou z hrozeb destabilizace v regionu. Náhlá eskalace násilí v roce 2016, známá jako Čtyřdenní válka, rozproudila novou diskuzi o faktorech ovlivňujících teritoriální spor mezi Arménií a Ázerbájdžánem. Zatímco soupeřící strany vysvětlují náhlý konflikt bud' jako reakci na vojenské provokace či snahu odvrátit pozornost od domácích problémů, v tomto článku je současná dynamika konfliktu vysvětlena také skrze působení mocenských zájmů třetí strany, Ruska. To považuje Kavkaz za svou sféru vlivu a automaticky se tak snaží o rozšíření své kontroly skrze posilování strategických vazeb s Arménií i Ázerbájdžánem, aby zabránilo mocenské projekci Západu v regionu. Ruská pozice velmoci má tak zásadní dopad na vývoj konfliktu v Náhorním Karabachu.

Abstract: Frozen conflict in Nagorno Karabakh has been representing a threat to the regional stability for the last two decades. Sudden escalation of violence in 2016, known as Four-Day War, spurred new discussions on factors influencing the territorial dispute between Armenia and Azerbaijan. While adversaries explain the conflict as a reaction to military provocations or as a rally round the flag effect, this article explains the dynamics of the conflict through the influence of the third party Russia. Russia considers the Caucasus to be its sphere of the influence and therefor aims to spread its control through strengthening strategic ties with both Armenia and Azerbaijan in order to prevent the West from projecting its power in the region. Russia's role of the superpower has therefor a vast influence on the Nagorno Karabakh conflict development.

Klíčová slova: Rusko; Náhorní Karabach; Arménie; Ázerbájdžán; zamrzlý konflikt; Čtyřdenní válka; Kavkaz; sféra vlivu.

Key words: Russia; Nagorno Karabakh; Armenia; Azerbaijan; Frozen Conflict; Four Day War; Caucasus; Sphere of Influence. 


\section{ÚVOD}

V dubnu 2016 otřásla Náhorním Karabachem nečekaná vlna násilí mezi arménskou a ázerbajdžánskou armádou, známá jako tzv. Čtyřdenní válka. Tento incident přinesl Ázerbájdžánu poprvé od příměři v roce 1994 teritoriální zisk, byt marginální, zatímco arménské síly na linii dotyku zastihl relativně nepřipravené. Náhlá eskalace zamrzlého konfliktu a hrozba destabilizace, jež s sebou tento vojenský střet přinesl, přitáhla také pozornost mezinárodního společenství. Před vypuknutím tohoto konfliktu docházelo na sporném území spíše sporadicky $\mathrm{k}$ otevřeným vojenským střetům, jež by měly za následek ztráty na životech, zároveň však obě strany každý den hlásily i stonásobné porušení príměří, přestože se ve většině prípadů jednalo pouze o přeshraniční střelbu bez reálných škod.

již před znovuuzavřením příměří obě strany uveřejnily řadu interpretací a vysvětlení týkajících se iniciace konfliktu. Ázerbájdžán tuto operaci vysvětloval jako odpověd' na vojenské provokace ze strany Arménie. Arménská strana naopak tuto akci označila za bezprecedentní útok ze strany Ázerbájdžánu a spolu s řadou zástupců mezinárodní komunity obvinila Ázerbájdžán z využití tzv. rally round the flag efektu, tedy z odvrácení pozornosti od domácích problémů vyvoláním konfliktu, jež sjednotí obyvatelstvo skrze národní zájmy. ${ }^{1}$

Tento článek si klade za cíl doplnit existující diskurz týkající se Čtyřdenní války o analýzu vlivu prosazování strategických cílů Ruska v regionu skrze rozbor široké škály aspektů ruské zahraniční politiky. Projekce ruských zahraničních zájmů a ruská zahraniční politika jsou $v$ této analýze považovány za jeden $z$ determinantů dynamiky zamrzlého konfliktu v Náhorním Karabachu. Ten bude zkoumán $v$ kontextu ruské bezpečnostní strategie a v návaznosti na rozšiřování a upevňování ruské sféry vlivu. Sledovaným indikátorem rozmrzání konfliktu jsou změny $v$ dynamice rusko-arménského a rusko-ázerbájdžánského partnerství, jež je dána do kontextu vývoje bezpečnostní situace na linii dotyku.

\section{LOGIKA ZAHRANIČNÍ POLITIKY RUSKA}

Rusko považuje Kavkaz za svou nárazníkovou zónu a je tedy automaticky znepokojeno hrozbou oslabení svého postavení v regionu a nestability, jež s sebou přináší přitomnost sporů o de facto státy nebo výrazný vliv dalších aktérů v této oblasti. Snaha o konsolidaci regionálních vztahů, popř́padě kontrola jejich dynamiky, je jedním ze strategických zájmů Ruska. Zatímco sporné oblasti, jako je Jižní Osetie a Abcházie, jsou pod prímou kontrolou Ruska, Náhorní Karabach je územím bez přímého ruského vlivu, nicméně projekce ruské moci je zde rovněž patrná.

1 BAKER, William D. a John R. O'NEAL. Patriotism or Opinion Leadership? Journal of Conflict Resolution, 2001. DOI: 10.1177/0022002701045005006. ISBN 10.1177/0022002701045005006. Dostupné také z: http://journals.sagepub.com/doi/10.1177/0022002701045005006 
V tomto článku je ruská zahraniční politika chápána jako produkt pragmatismu a racionalismu, jenž iniciuje snahu státu prosazovat své zájmy. Na zahraniční politiku Ruska pak Ize nahližet prismatem strategické volby, jež vysvětluje chování určitého aktéra v závislosti na jeho zájmech a zároveň přihliží na existenci dalších aktérů, kteří rovněž činí určitá rozhodnutí v rámci prosazování svých cílů. ${ }^{2}$ Za racionalistickými postoji Ruska stojí úsilí o podporu ekonomického růstu spolu s potřebou rozšiřovat a udržovat svou velmocenskou roli. V Koncepci zahraniční politiky Ruské federace z roku 2016 je jako jeden z hlavních cílů vytyčena snaha udržet a rozvíjet roli Ruska jako centra vlivu v dnešním světě. Tento cíl by měl být prosazován skrze řadu ekonomických, diplomatických a bezpečnostních aktivit, na regionální úrovni pak například skrze konsolidaci vztahů s Gruzií, asistenci v rozvoji a emancipaci Jižní Osetie a Abcházie či skrze urovnání sporu o Náhorní Karabach a Podněstří. ${ }^{3}$

Konflikt v Náhorním Karabachu a jeho dynamiku pak Ize chápat jako produkt nejen vnitřní politiky Arménie a Ázerbájdžánu, ale také jako výsledek působení třetích stran, jejichž aktivity bud' upevňují, nebo naopak narušují status quo. K ruskému vlivu na konflikt v Náhorním Karabachu Ize také přistupovat z hlediska teoretického rámce intervence třetí strany. Třetí strana v řešení konfliktu má přimět soupeříí státy $\mathrm{k}$ mírové dohodě skrze poskytování agendy v procesu vyjednávání. Třetí strana rovněž může působit jako garant dohody mezi znepřátelenými aktéry a také může nabídnout řadu pojistek pro prípad, že by mírová jednání selhala. ${ }^{4}$ Dalším pojmem, se kterým bude tato analýza pracovat, je koncept sféry vlivu, skrze který Ize nahlížet na mezinárodní řád. Tento pojem mưžeme definovat jako př́pad, kdy je určitá geografická oblast naplněna působením jedné mocnosti, jež zabraňuje v pronikání dalším mocnostem. Jedná se o teritorium, ve kterém vnější síla posiluje svůj vliv, čímž omezuje nezávislost přítomných států. ${ }^{5}$ Sféra vlivu v tomto článku je pak chápána jako politický konstrukt, který vede státy $\mathrm{k}$ určitému chování a prosazování svých zahraničních zájmů s tím, že hlavním zdůvodněním pro takové chování je udržení a prohloubení státní bezpečnosti skrze kontrolu oblastí strategicky propojených s daným státem.

\section{DVOJí ROLE RUSKA V ŘEŠENÍ KONFLIKTU}

Roli Ruska v řešení zamrzlého konfliktu v Náhorním Karabachu Ize zkoumat na dvou úrovních a to z pozice Ruska v Minské skupině a z pozice Ruska jako samostatného státu prosazujícího své zájmy a cíle pomocí multilaterálních i bilaterálních nástrojů. Od roku

2 Arthur Stein. The Limits of Strategic Choice. In: Strategic Choice and International Relations, pp. 197-228, Edited by David A. Lake and Robert Powell. Princeton, New Jersey: Princeton University Press, 1999.

3 Koncepcija vnješnej politiki Rassijskoj Federacii, 2016. Dostupné z: http://www.mid.ru/web/guest/ foreign_policy/official_documents/-/asset_publisher/CptICkB6BZ29/content/id/2542248

4 RIOUX, Jean-Sébastien; Jean-Christophe BOUCHER. Third Party Intervention as Conflict Management: The Case of Africa. 16th Nordic and 4th Baltic Peace Research Conference, St. Petersburg, 2003

5 HATS, Susanna. Spheres of Influence in International relations. Routledge, 2016. ISBN 978-952-484-571-7 
1992 je Rusko spolu s Francií a Spojenými státy předsedající zemí Minské skupiny OBSE, jejímž hlavním cílem je nalezení mírového řešení konfliktu mezi Arménií a Ázerbájdžánem. ${ }^{6}$ Práce Minské skupiny je kritizována oběma stranami konfliktu i mezinárodním společenstvím pro absenci výsledků vyjednávání. ${ }^{7}$ Ruský vliv na vývoj konfliktu v Náhorním Karabachu tak Ize zkoumat především skrze jeho samostatné aktivity v rámci prosazování svých strategických zájmů a posilování své sféry vlivu v regionu. $V$ rámci Minské skupiny se totiž Rusko většinou pouze připojuje $k$ relativně vágním prohlášením, reagujícím na střety na linii dotyku. Ve své vlastní gesci naopak Rusko nabízí řadu příležitostí k vyjednávání a staví se do role hlavního mediátora.

\section{RUSKO-ARMÉNSKÉ A RUSKO-ÁZERBÁJDŽÁNSKÉ VZTAHY}

Rusko-arménské a rusko-ázerbajdžánské vztahy procházely od vzniku samostatných republik dynamickým vývojem a sovětský postoj vůči pokusům Náhorního Karabachu o připojení k Arménii či o osamostatnění byl z počátku konfliktu zamítavý. Sovětský svaz původně stál na straně Ázerbájdžánu. Toto rozhodnutí vycházelo ze strachu ze vzniku nových secesionistických hnutí. Po rozpadu SSSR se politika výlučné politické a vojenské podpory Ázerbájdžánu změnila a Rusko začalo dodávat zbraně také Arménii. ${ }^{8}$ Ázerbajdžánská armáda nebyla před zamrznutím konfliktu sto čelit vojenské síle Arménie a musela v roce 1992 ustoupit z celého území Náhorního Karabachu a přilehlých okresů. Během konfliktu přišly o život více než dvacet tisíc vojáků i civilistů na obou stranách a až po nátlaku Ruska i mezinárodního společenství a díky nedostatku vojenských kapacit na obou stranách konfliktu bylo podepsáno príměří. ${ }^{9}$ Po jeho uzavření v roce 1994 se Rusko stalo nejbližším arménským spojencem a Arménie jediným strategickým partnerem Ruska na Jižním Kavkaze. ${ }^{10}$ Kromě prítomnosti ruských jednotek na arménském území, které mají mimo jiné za úkol pomáhat při střežení hranic s Tureckem a Íránem, se Moskva také zavázala ke každoročnímu školení arménských důstojníků. ${ }^{11}$

6 MOORADIAN, M. a D. DRUCKMAN. Hurting Stalemate or Mediation? The Conflict over Nagorno-Karabakh, 1990-95. DOI: 10.1177/0022343399036006007. ISBN 10.1177/0022343399036006007. Dostupné také z: http://jpr.sagepub.com/cgi/doi/10.1177/0022343399036006007

7 Format of OSCE Minsk Group doomed to failure [online]. Jerevan: Armenia News, 2010 [cit. 2017-02-25]. Dostupné z: https://news.am/eng/news/43306.html

8 CHORBAJIAN, Levon, Patrick DONABÉDIAN a Claude MUTAFIAN. The Caucasian knot: the history. London: Zed Books, 1994. ISBN 978-1856492874.

9 SOULEIMANOV, Emil. Understanding ethnopoitical conflict: Karabakh, South Ossetia, and Abkhazia wars reconsidered. Springer, 2013. ISBN 978-1-137-28023-7.

10 FREIZER, Sabine. Twenty years after the Nagorny Karabakh ceasefire: an opportunity to move towards more inclusive conflict resolution. DOI: 10.1080/23761199.2014.11417295. ISBN 10.1080/23761199.2014.11417295. Dostupné z: http://www.tandfonline.com/doi/full/10.1080/23761 199.2014.11417295

11 GAZARYAN, Karen. Strategičeskoje partnerstvo Rassiji i Armeniji. Informacionno-analitičeskij Centr, 2008. Dostupné z: http://ia-centr.ru/expert/1213/ 
I v ekonomické oblasti má Rusko ve vztahu k Arménii výsadní postavení a další státy investující v Arménii nepředstavují pro Rusko výraznou konkurenci. Mezi Ruskem a Arménií totiž existuje více než dvě stě mezistátních a meziresortních smluv a dohod a každým rokem dochází k podpisu nových smluv týkajících se především ekonomické spolupráce. ${ }^{12}$ Rusko jako významný investor do arménské ekonomiky ročně přináší stovky miliónů dolarů a to především v oblasti bankovnictví a energetiky a zaměřuje se i na dovoz strategických surovin a materiálů. ${ }^{13}$

Partnerství mezi Ázerbájdžánem a Ruskem rovněž nelze marginalizovat, přestože Ázerbájdžán na Rusko nikdy nenahlížel jako na výlučného partnera a snažil se rozšiřovat spolupráci s dalšími státy. Rusko-ázerbájdžánské vztahy po rozpadu Sovětského svazu byly založeny převážně na ekonomické výměně a ruská podpora Arménie v kontextu Náhorního Karabachu byla jednou z hlavních překážek v započetí úzké spolupráce v oblasti bezpečnostní a vojenské. Po získání nezávislosti začal Ázerbájdžán rož̌iřovat svou spolupráci především s Evropskou unií, jež byla roku 1996 završena Dohodou o partnerství a spolupráci. Ázerbájdžán rovněž přijal Akční plán Evropské politiky sousedství. Evropskou unii a Ázerbájdžán také pojí společné zájmy v energetické politice. ${ }^{14}$ Nejen Evropská unie, ale také Spojené státy významným způsobem měnily své vztahy s Ázerbájdžánem. Jednalo se jak o jejich aktivní roli v Minské skupině, která měla vytvářet půdu pro další vyjednávání mezi Arménií a Ázerbájdžánem, tak i o uvalení embarga, jež zakazovalo poskytovat ázerbajdžánské vládě jakoukoli přímou pomoc ze strany Spojených států. Od tohoto zákazu nakonec upustil G. W. Bush a také jeho nástupce Barack Obama. ${ }^{15}$ Ázerbájdžán totiž spolupracoval se Spojenými státy na poli energetické bezpečnosti a poskytl Spojeným státům podporu během války v Iráku, Afghánistánu i během aktivit spojených s bojem proti terorismu. ${ }^{16}$ Je logické, že ve světle tohoto partnerství se Rusko rozhodlo svou moc $\checkmark$ regionu upevnit a nenechat další aktéry, aby rozšiřovaly svůj vliv skrze spolupráci v oblasti, kterou Rusko považuje za svou výsadní sféru vlivu. Klíčovým aktérem, kterého se v tomto regionu Rusko snaží nahradit, je Turecko. To je vnímáno jako dlouhodobý a nejbližší spojenec Ázerbájdžánu a zároveň se i přes řadu dohod podporujících spolupráci stalo soupeřem Ruska jak v Sýrii, tak i v Černém moři a na Kavkaze. ${ }^{17}$

12 Mežgosudarstvennyje otnošenija Rassiji i Armeniji.. RIA Novosti 2017, Dostupné z: https://ria.ru/ spravka/20170314/1489870795.html

13 GAZARYAN, Karen. Strategičeskoje partnerstvo Rassiji i Armeniji. Informacionno-analitičeskij Centr, 2008. Dostupné z: http://ia-centr.ru/expert/1213/

14 FRANKE, Anja, Andrea GAWRICH, Inna MELNYKOVSKA a Rainer SCHWEICKERT. The European Union's Relations with Ukraine and Azerbaijan. DOI: 10.2747/1060-586X.26.2.149. ISBN 10.2747/1060586X.26.2.149. Dostupné z: http://bellwether.metapress.com/openurl.asp?genre=article

15 BABAN, Inessa; SHIRIYEV, Zaur. The US South Caucasus Strategy and Azerbaijan. Turkish Policy Quarterly, 2010, p. 93-103.

16 WISHNICK, Elizabeth. Growing US Security Interests in Central Asia. DIANE Publishing, 2002. ISBN 9781428910980.

17 HEDENSKOG, Jakob; KORMAZ, Kaan. The Interests of Russia and Turkey in the Nagorno-Karabakh Conflict. FOI 2016. Dostupné z: https://www.foi.se/download/18.1b4084ea15549d027d14b79/1466509555042/ RUFS+Briefing+No.+35+.pdf 
Nalézt cestu k Ázerbájdžánu jako ke svému spojenci byl pro Moskvu další klíčový úkol. Překážkou bylo strategické partnerství s Arménií, významné dodávky ruských zbraní putujících z Jerevanu do Stěpanakertu a především role Ruska jako de facto garanta statusu quo v Náhorním Karabachu. Rusko vždy zdůrazňovalo svou neutrální pozici v karabašském konfliktu, zároveň však bylo vždy schopné vyvinout dostatečný tlak na obě strany, aby se vyvarovaly otevřeného konfliktu. I z toho důvodu střety na linii dotyku mezi ázerbájdžánskými a arménskými silami až do roku 2016 nikdy nevypukly naplno, přestože oba státy disponovaly rozsáhlým vojenským arzenálem.

Právě vojenská síla obou států a import zbraní ze zahraničí poukazuje na paradoxní vztah Ruska a těchto dvou kavkazských zemí. Od roku 1994 je totiž Rusko největším dodavatelem zbraní jak do Arménie, tak do Ázerbájdžánu. Do roku 2016 šlo u Arménie o dodávky za 556 milionů dolarů, což jsou čtyři pětiny celkových nákladů, které Arménie od svého vzniku na nákup zbraní v zahraničí vynaložila. V případě Ázerbájdžánu se jednalo o částku dvou miliard dolarů, tedy dvě třetiny celkových nákladů na import zbraní od začátku samostatného státu. ${ }^{18}$

Při analýze dat z databáze transferů zbraní do zkoumaných států je možné si povšimnout několikanásobného nárůst výdajů, ke kterému v Ázerbájdžánu došlo v roce 2011. Další nárůst byl zaznamenán i v roce 2014. Někteří analytici na arménské straně poukazují na tento fakt s tím, že nákup nových zbraní může vést ke zvýšení incidentů na linii dotyku, jelikož si velitelé budou chtít vyzkoušet nové zbraně v praxi. V kontrastu s těmito údaji u Arménie nedocházelo k výrazným odchylkám v nákladech na import armádního vybavení a zároveň je zde znatelný i rozdíl v diverzifikaci dodavatelů, kdy Arménie v minulosti získala kromě Ruska větší armádní dodávky jen z Ukrajiny a Slovenska, zatímco rejstřík dodavatelů pro Ázerbájdžán je širší. Přestože u nákladů na vojenské vybavení hraje důležitou roli státní rozpočet, který je u Ázerbájdžánu několikanásobně vyšší, než u Arménie, je zjevné, že Arménie vojensky je schopná mu vojensky čelit, přestože spoléhá na podporu Ruska. ${ }^{19} \mathrm{U}$ Ruska naopak nelze předpokládat, že by se vzdalo své neutrální strategické pozice a rozhodlo se pro vojenskou asistenci Arménii v případě rozsáhlejších vojenských operací ze strany Ázerbájdžánu. Není totiž pravděpodobné, že by v takovém případě zásobilo Ázerbájdžán tak vysokým objemem zbraní, kterým by pak samo muselo v prípadě zapojení se do konfliktu čelit. ${ }^{20}$ Vojenské spojenectví mezi Arménií a Ruskem však funguje jako optimální nástroj odstrašení a vnáší do vývoje konfliktu v Náhorním Karabachu specifickou dynamiku. Ruská vojenská př́tomnost je v Arménii patrná i díky vojenské základně v Gyumri, jednotkám chránícím hranice s Tureckem a Íránem, či letecké základně v Erebuni. ${ }^{21}$ Arménie a Rusko jsou také spolu s Běloruskem, Kazachstánem, 
Kyrgyzstánem a Tádžikistánem aktivními členy Organizace Smlouvy o kolektivní bezpečnosti. ${ }^{22}$ Od roku 2016 mezi Ruskem a Arménií rovněž funguje společný systém vzdušné obrany. Pozornost vyvolalo také předání balistických střel Iskander-M arménské armádě v létě roku 2016. ${ }^{23}$ I přes upevňování vojenských vazeb však Rusko do bojů v Náhorním Karabachu vojensky nezasáhlo (alespoň ne oficiálně), jelikož Náhorní Karabach, jako de facto stát, není členem žádné z vojenských a bezpečnostních smluv, ve kterých Rusko a Arménie figuruje a z toho důvodu není Rusko zavázáno k vojenské intervenci v prípadě jeho napadení.

\section{RUSKO A VOJENSKÁ DIMENZE KONFLIKTU}

Reakci Ruska na vyostření náhornokarabašského konfliktu bylo možné sledovat v rámci dvou případů eskalace násilí na linii dotyku a to jak v srpnu 2014, tak během tzv. Čtyřdenní války v dubnu 2016. Rusko v těchto případech nijak vojensky nezasáhlo, nicméně $z$ jeho strany došlo $k$ rozsáhlé diplomatické intervenci v obou př́padech. ${ }^{24}$ Do konfliktu nevstoupil ani žádný jiný stát Organizace Smlouvy o kolektivní bezpečnosti, jež by byla povinna reagovat pouze $v$ př́padě, že by se boje přelily na oficiální arménské území. Během eskalace konfliktu $v$ roce 2014 přišlo o život dvacet lidí, nicméně boje se nikdy nerozhořely do intenzity Čtyřdenní války, přestože trvaly dvanáct dní a Ázerbájdžán disponoval zásadní převahou ve vojenské technice. Musel zde tedy být přítomný jiný faktor, který boje udržel na velmi omezené úrovni. Z mírových vyjednávání, na která prezident Putin pozval hlavy obou států do Soči je zřejmé, že to byl právě tlak Ruska, který zamezil dalšímu pokračování ozbrojeného konfliktu. Hned při vypuknutí bojů Rusko označilo jakoukoli další eskalaci násilí a porušování uzavřeného příměří za nepřijatelné. ${ }^{25}$ Státy se musely požadavku Ruska podř́idit a konflikt se udržel na limitované úrovni, přestože príměří nebylo vyhlášeno ihned. Arménie s príměřím souhlasila z pozice závislého spojence a Ázerbájdžán se podřídil s vědomím, že jakékoli další vojenské operace, které by vystoupily z rámce omezeného konfliktu, by mohly výrazně narušit jeho vztahy s Moskvou. Povaha bojů z dubna 2016 je však diametrálně odlišná. Přestože tato náhlá eskalace násilí na linii dotyku trvala o dvě třetiny kratší dobu než střety v roce 2014, jednalo se co do intenzity o největší vypuknutí bojů od príměří v roce 1994. Započetí vojenských

22 FROST, Alexander. The Collective Security Treaty Organization, the Shanghai Cooperation Organization, and Russia's Strategic Goals in Central Asia. In: China and Eurasia Forum Quarterly, s. 83-102, 2009.

23 Armenia Acquires New Russian Missiles... Or Did It?: http://www.eurasianet.org/node/80596 [online]. EurasiaNet, 2016 [cit. 2017-02-15]. Dostupné z: http://www.eurasianet.org/node/80596

24 MUCHANOV, Vadim, M. Rassiju vtjagivajut $v$ vojnu na Kavkaze. Centr problem Kavkaza i regionalnoj bezopasnosti MGIMO, 2016. Dostupné z: https://mgimo.ru/about/news/experts/rossiyu-vtyagivayut-vvoynu-na-kavkaze/?sphrase_id=5919640

25 Nagorno-Karabakh violence: Worst clashes in decades kill dozens [online]. UK: BBC News, 2016 [cit. 201703-12]. Dostupné z: http://www.bbc.com/news/world-europe-35949991 
operací ve formě blitzkriegu ze strany Ázerbájdžánu bylo strategickým překvapením jak pro síly Náhorního Karabachu, tak pro mezinárodní společenství. ${ }^{26}$

Mechanismus, jenž spustil eskalaci násilí, byl de facto totožný s mechanismem z roku 2014. I zde Ázerbájdžán uvádí jako spouštěcí incident údajnou provokaci ze strany Arménie, přestože tato informace nebyla potvrzena z nezávislých zdrojů. Tato odvetná reakce však dosáhla nečekané síly, jež byla překvapivá i z hlediska dosavadní politiky udržování bojů na takové úrovni, jež by neznepokojila Rusko. Z nasazené vojenské techniky a z intenzity vojenských operací je však zřejmé, že Ázerbájdžán si byl v tomto př́padě nechutí Ruska vojensky intervenovat jistý, v opačném případě by pravděpodobně volil opatrnější postup. Během vojenských operací se Ázerbájdžánu podařilo získat menší část sporného území pod svou kontrolu a vláda v Baku si tak upevnila v očích obyvatel svou pozici. $Z$ bojů totiž Ázerbájdžán poprvé vzešel dle své rétoriky jako vítěz a to především díky momentu překvapení, během kterého se ázerbajdžánské armádě podařilo získat několik strategických bodů, jejichž část se však arménským silám podařilo vybojovat zpět.. ${ }^{27}$ Tato operace tak mohla rovněž sloužit jako demonstrace síly a nástroj nátlaku ze strany Ázerbájdžánu, neoficiálně podporovaného Moskvou, s cílem přivést Arménii k ústupkủm během vyjednávání. Tento vojenský střet opět potvrdil, že Rusko není ochotné do sporů o Náhorní Karabach vojensky zasáhnout.

Během rozhovorů vedených $v$ rámci výzkumu zamrzlých konfliktů $s$ řadou zahraničních diplomatů a expertů v Ázerbájdžánu, padl několikrát nepotvrzený názor o pravděpodobném přímém př́kazu $\mathrm{k}$ zastavení bojů ze strany Moskvy, jenž ukončil operace ázerbajdžánských jednotek a odvetné akce karabašských ozbrojených sil. Dále byly opakovaně zmíněny vojenské konzultace, jež probíhaly mezi Baku a Moskvou. Toto vysvětlení se zdá logické i z hlediska celonárodní podpory obyvatel Ázerbájdžánu, kterou si dubnová vojenská kampaň získala a jež by byla logickým stimulem pro pokračování bojů ve snaze o další teritoriální zisky. Toto prání veřejnosti však nebylo vyslyšeno a Ázerbájdžán vojenské operace zastavil. Vojenské operace zastavily i síly Náhorního Karabachu, přestože měly možnost získat ztracené území zpět. Názor arménských analytiků na roli Ruska v eskalaci konfliktu se liší. Na rozdíl od ázerbajdžánské strany ve většině príipadů arménští odborníci nevnímají Rusko jako klíčového aktéra ovlivňujícího iniciaci a průběh vojenských operací, pouze jako aktéra mající zásadní vliv na deeskalaci konfliktu. Také vylučují, že by Rusko dalo Ázerbájdžánu v iniciaci konfliktu volnou ruku. Někteří se však domnívají, že schopnost Ruska přivést obě strany k vyjednávacímu stolu ve velmi krátkém čase od vypuknutí bojů, byla hlavním záměrem Moskvy s cílem zvýšit kredit Ruska v očích mezinárodní komunity a otevř́t tak Rusku potenciální možnost vyslat v budoucnu své mírové jednotky na sporné území a ještě více tak posílit jeho vliv v regionu.

Rozhovory s diplomaty a dalšími odborníky na obou stranách konfliktu poukázaly i na fakt, že duben a jaro všeobecně představuje období náchylné $k$ vypuknutí vojen-

26 The risk of renewed hostilities over Nagorno-Karabakh [online]. Global Risk Insight, 2016 [cit. 2017-0312]. Dostupné z: http://globalriskinsights.com/2016/04/renewed-hostilities-nagorno-karabakh/

27 JAROSIEWICZ, Aleksandra. The four-day war in Nagorno-Karabakh [online]. Osrodek Studiow Wschodnich, [cit. 2017-03-10]. Dostupné z: https://www.osw.waw.pl/en/publikacje/analyses/2016-04-06/four-daywar-nagorno-karabakh 
ských střetů na linii dotyku, jelikož se armády, jež se z některých bodů na zimu stahují, opět snaží dosáhnout svých loňských pozic, poprípadě zabrat i další území a je tedy logické, že v takovém prípadě je možná vojenská eskalace více než pravděpodobná.

\section{DIPLOMATICKÁ VYJEDNÁVÁNÍ PO VYPUKNUTÍ KONFLIKTU}

Rusko bylo prvním státem, který na vypuknutí bojů reagoval a prezidenti Sargsjan i Alijev opakovaně konzultovali situaci s Vladimírem Putinem. Opětovné příměří pak bylo dohodnuto v Moskvě s náčelníky generálních štábů obou zemí. ${ }^{28}$ Zajímavým momentem je, že v průběhu konfliktu byli oba prezidenti prítomní ve Spojených státech na summitu věnovaném jaderným otázkám, pořádaným prezidentem Obamou. Americká strana se pokusila dojednat setkání mezi Alijevem a Sargsjanem, ke kterému však nakonec nedošlo a Rusko tak mohlo znovu poukázat na své výlučné schopnosti při vyjednávání príměří, zatímco další členové Minské skupiny selhali. ${ }^{29}$ Po příměří následovala řada rozhovorů mezi ruským premiérem Medveděvem, ministrem zahraničí Lavrovem a arménskými a ázerbajdžánskými představiteli. Vyjednávání však opět nevedla ke změně statusu quo, pouze poukázala na hluboko zakořeněný problém, jenž samotné vyjednávání pravděpodobně není schopné vyřešit. ${ }^{30}$

Bezprecedentní intenzita útoku ze strany Ázerbájdžánu pritáhla pozornost mezinárodní komunity a jako hlavní vítěz z tohoto incidentu vyšlo Rusko, které bylo během enormně krátkého času schopné dojednat príměři a představilo tak svou roli jediného aktéra schopného přinést stabilitu do regionu a iniciovat společný dialog znepřátelených stran. Klíčový materiál, využívaný při současných vyjednáváních o možném mírovém řešení karabašského konfliktu je tzv. Lavrovův plán, jenž nabízí mírový scénář postupného řešení nejdůležitějších otázek a je dalším dokumentem poukazujícím na výsadní roli Ruska jako mediátora. ${ }^{31}$

Pří analýze náhlé změny intenzity konfliktu v Náhorním Karabachu, nahližené prizmatem ruské strany, je zapotřebí si uvědomit změny $v$ ruské zahraniční strategii ve snaze umocnit svou roli na Jižním Kavkaze. Postoj k Arménii se neměnil, partnerství s ní se každým rokem upevňovalo a pro Arménii se stalo Rusko de facto výlučným strategickým partnerem, jenž má díky členství obou zemí v Organizaci Smlouvy o kolektivní bezpeč-

28 Putin's Phone Talks with Aliyev and Sargsyan [online]. Contact.az, 2016 [cit. 2017-03-10]. Dostupné z: http://www.contact.az/docs/2016/Politics/040500151854en.htm\#.WMmWdG_hDRY

29 DE WAAL, Thomas. Čem opasno obostrenje v Karabache. Carnegie Moscow Center, 2016. Dostupné z: http://carnegie.ru/commentary/63215

30 ZOLJAN, Mikael. Preventing Escalation in the Nagorno-Karabakh Conflict: Threats to Euro-Atlantic Security and Opportunities for Euro-Atlantic Cooperation [online]. 2016, 3-34 [cit. 2017-03-12]. Dostupné z: http://www.europeanleadershipnetwork.org/medialibrary/2016/10/17/78e153f5/Hurford\%20-\%20 Zolyan.pdf

31 RASULZADE, Zaur. Will Azerbaijan and Armenia accept "Lavrov's plan"? Eurasia Daily, 2016. Dostupné z: $\quad$ https://eadaily.com/en/news/2016/05/31/will-azerbaijan-and-armenia-accept-lavrovs-plan-viewsfrom-baku 
nosti možnost určovat, jaké vojenské základny mohou či nemohou být v Arménii budovány či s kým Arménie smí započít vojenskou spolupráci. ${ }^{32}$ Změny však nastaly ve vztahu Ruska k Ázerbájdžánu. Aby Rusko omezilo vliv Západu na území, jež považuje za svou sféru vlivu, muselo změnit postoj Ázerbájdžánu skrze nabídku partnerství, jemuž západní země nemohou konkurovat. $V$ tomto př́padě se mohlo jednat právě o nabídku neoficiální pomoci při řešení konfliktu v Náhorním Karabachu. Již od roku 2008 začalo Rusko aktivně vyhledávat oblasti, ve kterých by mohlo prohloubit své partnerství s Ázerbájdžánem, a od roku 2015 tuto snahu o novou strategickou spolupráci ještě navýšil.

Přestože se Ázerbájdžán k určitým zahraničním aktivitám Ruska snaží stavět neutrálně a v některých případech, jako v otázce krize na Ukrajině, také kriticky, intenzita kontaktů mezi politickými představiteli Ruska a Ázerbájdžánu v roce 2015 začala narůstat a Rusko představilo řadu strategických dokumentů, ve kterých chce posilovat spolupráci s Ázerbájdžánem. ${ }^{33}$ I tato diplomatická jednání mohla vzbudit v Arménii obavy ze změny ruské politiky vůči Náhornímu Karabachu. ${ }^{34} \mathrm{Na}$ základě strategického partnerství mezi Arménií a Ruskem Ize totiž předpokládat, že Rusko má natolik silný vliv na vnitřní i vnější politiku Arménie, že by bylo schopné ji donutit k výrazným ústupkům v prospěch Ázerbájdžánu. I na tuto situaci jednostranné závislosti a oficiální neutrální postoj Ruska poukazují arménští analytici, kteří v posledních letech zaznamenali výrazný nárůst proti-ruských nálad $v$ arménské společnosti.

Současná patová situace, ve které není pravděpodobné, že by ázerbajdžánská strana získala své teritorium zpět, nebo že by neuznaná vláda Náhorního Karabachu získala požadovanou suverenitu, vyhovuje především Rusku. Vyřešení zamrzlého konfliktu v Náhorním Karabachu cestou návratu území pod ázerbajdžánskou správu by pro region totiž znamenalo zásadní precedens s ohledem na další konflikty, zejména pokud se jedná o otázku Krymu, ale i Podněstří nebo Jižní Osetie a Abcházie. Změna současného stavu by tak poškodila ruské zájmy $v$ regionu. $V$ neposlední řadě by i pro Ázerbájdžán bylo navrácení sporných území zásadním problémem a to především z hlediska financování repatriace, rekonstrukce kritické infrastruktury atd.

\section{ZÁVĚR}

Zamrzlý konflikt v Náhorním Karabachu se stal fenoménem, jehož dynamika zásadním způsobem ovlivňuje stabilitu regionu. $V$ tomto článku byly zmapovány dva prípady eskalace a deeskalace vojenských střetů mezi Arménií a Ázerbájdžánem a následně posta-

32 FROST, Alexander. The Collective Security Treaty Organization, the Shanghai Cooperation Organization, and Russia's Strategic Goals in Central Asia. In: China and Eurasia Forum Quarterly. 2009. p. 83-102.

33 Azerbaijan-Russia economic co-op promotes business ties [online]. AZERNEWS, 2015 [cit. 2017-03-13]. Dostupné z: http://www.azernews.az/business/89180.html

34 LARSEN, Joseph. Russia's Double Dealing in Armenia and Azerbaijan. International Policy Digest [online]. 2016, [cit. 2017-03-15]. Dostupné z: https://intpolicydigest.org/2016/12/07/russia-s-double-dealingarmenia-azerbaijan/ 
veny do kontextu ruské zahraniční politiky. Na základě této analýzy můžeme konstatovat zásadní roli Ruska ve vzplanutí bojů na linii dotyku v roce 2016. V tomto světle se pak nejedná pouze o spor mezi dvěma suverénními aktéry, nýbrž o spor mezi dvěma aktéry, jejichž rozhodování je $v$ mnoha ohledech závislé na postojích třetí strany.

První pozice, skrze kterou Rusko tento konflikt ovlivňuje, je role mediátora, jež Rusku přináśí mezinárodní kredit jako aktérovi schopnému poskytnout znepřáteleným stranám agendu pro vyjednávání a schopnému přimět bojující strany $k$ ukončení násilností a k opětovnému uzavření příměří. $V$ druhé řadě může být Rusko chápáno jako garant statusu quo, jehož vojenská prítomnost v regionu, strategické partnerství s Arménií a dobré vztahy s Ázerbájdžánem zabraňují vypuknutí konfliktu v plném měřítku, stejně jako zabraňují řešení, jež navrhují zneprátelené strany. Dále Rusko disponuje pozicí dohlížitele na prípadné vojenské incidenty, jejichž délku i intenzitu může díky svému velmocenskému postavení významným způsobem regulovat.

Role Ruska je tedy kličová z hlediska dynamiky konfliktu a dovoluje pochopit průběh jednotlivých incidentů. Je zásadní i pro modelaci prípadných návrhů mírového řešení. $\checkmark$ současné době je rovněž zřejmé, že status quo v Náhorním Karabachu přináší Rusku prospěch. Přestože Arménie již několikrát dokázala, že i pres vojenskou převahu je schopná Ázerbájdžánu čelit, jako osamocený stát však nemůže čelit hrozbě, již by pro ni představoval Ázerbájdžán $v$ prípadné vojenské spolupráci s Tureckem. $V$ takovém př́padě by byla závislá na vojenském spojenectví s Ruskem, které tak může na arménském území upevňovat svůj vliv. Př́tomnost konfliktu a patová situace rovněž napomáhá Rusku vybalancovat existující vazby Ázerbájdžánu se Západem, jelikož má dostatečné nástroje $\mathrm{k}$ tomu, aby $v$ budoucnu intervenovalo v prospěch Ázerbájdžánu. Možný přislib takové budoucí diplomatické intervence pak nutí i Baku udržovat s Ruskem dobré vztahy.

Tento článek vznikl v rámci výzkumného projektu „Indikátory včasného varování eskalace zamrzlých konfliktů (VI20152019011)“ financovaného Ministerstvem vnitra České republiky.

Autorka: Mgr. Pavlína Bláhová. Vystudovala obor Politologie a Mezinárodní vztahy na FSV UK a hlavní program Diplomatické akademie v Praze. Absolvovala radu odborných stáží např́klad na Ministerstvu zahraničních věcí ČR nebo $v$ Ústavu mezinárodních vztahů. Mimo jiné se zaměruje na oblast Kavkazu, Střední Asie a na problematiku mezinárodního organizovaného zločinu.

Jak citovat: BLÁHOVÁ, Pavlína. Vliv Ruska na dynamiku konfliktu v Náhorním Kara bachu. Vojenské rozhledy. 2017, 26 (3), 3-13. DOI: 10.3849/23362995.26.2017.03.003-013. ISSN 1210-3292 (print), 2336-2995 (on-line). Available at: www.vojenskerozhledy.cz 


\section{Energetika jako strategický nástroj hnutí Hizballáh v konfrontaci s Izraelem}

\section{Energy as a Strategic Tool of Hezbollah Movement in Confrontation with Israel}

\section{Lukáš Tichý}

Abstrakt: Článek se zaměřuje na konfrontaci libanonského šíitského hnutí Hizballáh $\mathrm{s}$ Izraelem v oblasti energetiky. Záměrem článku je analyzovat význam, jaký Hizballáh přisuzuje energetice, ve své strategii obecně a konkrétně $v$ konfrontaci s Izraelem a na cíle, motivy a metody energetické strategie hnutí Hizballáh. Primární metodu činnosti Hizballáhu představuje užití nebo hrozba násilí, které spočívá ve vyhrožování vojenským útokem na energetický sektor Izraele scílem bránit libanonské energetické bohatství a odradit svého nepřitele od produkce plynu a ropy ve sporných vodách východního Středomoří. Hlavním motivem těchto aktivit Hizballáhu je pak zejména posílení stabilních energetických dodávek a obvinění Izraele z agresivní energetické politiky vưči Libanonu.

Abstract: The article focuses on confronting the Lebanon's Shiite movement Hezbollah with Israel in the field of energy. The aim of the article is to analyse the importance of energy in strategy of movement Hezbollah generally and specifically in confronting with Israel and motives and methods of the energy strategy of the Hezbollah. The primary method of Hezbollah action is to use or threat of violence consisting in threatening to attack on the Israeli energy sector to defend Lebanese energy wealth and deter its enemy from production of gas and oil in the disputed waters of the eastern Mediterranean. The main motive of Hezbollah's activities is especially strengthening of stable energy supplies and Israel's accusations of aggressive energy policy towards Lebanon.

Klíčová slova: Hizballáh; energetika; šíitský islám; Izrael; Libanon.

Keywords: Hezbollah; Energy; Shiite Islam; Israel; Lebanon. 


\section{ÚVOD}

Libanonské hnutí později známé jako Hizballáh (česky „Strana boži“) bylo založeno šíitskými muslimy v severovýchodním Libanonu (údolí Biqa') v roce $1982 \mathrm{k}$ boji proti izraelské okupaci jižního Libanonu. Po skončení občanské války v roce 1990 sice hnutí prošlo podle Jana Daniela takzvaným procesem libanonizace, začalo participovat na libanonském politickém systému a uznalo libanonský stát (přičemž částečně zmírnilo svou islamistickou rétoriku), ale zároveň si se syrským posvěcením ponechalo své zbraně a vedlo na jihu země ozbrojený boj proti Izraeli. ${ }^{1}$ "Svého ozbrojeného kř́́dla se nevzdalo ani po odchodu Izraelců z okupovaného pásma na jihu Libanonu v roce 2000, ani po stažení syrské armády ze země v roce 2005. Své ozbrojence Hizballáh následně ve větší míre otevřeně využil během „letní války“ s Izraelci v roce 2006, při střetech se svými politickými oponenty v květnu 2008 a v současnosti v bojích s protiasadovskými povstalci v sousední Sýrii“. ${ }^{2} \vee$ čele Hizballáhu stojí sedmičlenná rada tvořená z většiny seniorními duchovními, přičemž formální hlavu hnutí představuje generální tajemník volený radou z vlastních řad (v současnosti Hasan Nasralláh). Hnutí je dále rozděleno na politickou a ozbrojenou část, které spadají pod přímé velení rady a na nižších úrovních fungují do jisté míry odděleně. ${ }^{3}$

$\checkmark$ tomto článku pak autor, v souladu s názorem Jana Daniela, chápe Hizballáh jako islamistické (politicky šíitské) sociální hnutí, které ovšem disponuje vlastními ozbrojenými složkami a využívá i teroristické metody boje. ${ }^{4}$ „Těžiště aktivit Hizballáhu (včetně těch, které jsou obvykle asociovány exkluzivně se státem, jako je právě ozbrojené zajištování bezpečnosti) a hlavní rozhodovací pravomoci v rámci hnutí ovšem leží mimo instituce libanonského státu a jsou na něm nezávislé, byt' je využívají v některých prípadech pro

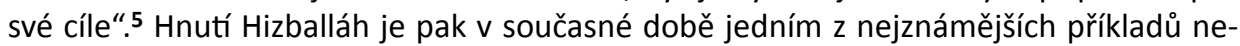
státního aktéra, který dlouhodobě de facto ovládá určité teritorium formálně náležející suverénnímu státu.

Hizballáh, který kdysi propagoval vytvoření islámského státu, byl jedním z průkopníků $v$ rozvoji energetické agendy mezi islamistickými organizacemi. Nicméně otázce energetické strategie Hizballáhu, v porovnání s jeho teroristickou činností a bojem proti Izraeli,

1 K tomu srov. DANIEL, J. (2014). Vládnutí nestátních ozbrojených aktérů v selhávajících státech: Př́pad Hizballáhu. Mezinárodní vztahy, roč. 49, č. 2, s.. 37, ale také AZANI, E. (2011). Hezbollah: The Story of the Party of God From Revolution to Institutionalization. New York: Palgrave Macmillan.

2 DANIEL, J. (2014). Vládnutí nestátních ozbrojených aktérů v selhávajících státech: Případ Hizballáhu. Mezinárodni vztahy, roč. 49, č. 2, s. 37, ale také HARIK, J., P. (2010). Force of Arms and Hizbullah's Staying Power in Precarious Lebanon. In: MULAJ, K. (ed.). Violent Non-State Actors in World Politics. New York: Columbia University Press, s. 149-153.

3 DANIEL, J. (2014). Vládnutí nestátních ozbrojených aktérů v selhávajících státech: Případ Hizballáhu. Mezinárodní vztahy, roč. 49, č. 2, s. 38.

4 Tamtéž, s. 38; AZANI, E. (2011). Hezbollah: The Story of the Party of God From Revolution to Institutionalization. New York: Palgrave Macmillan.

5 DANIEL, J. (2014). Vládnutí nestátních ozbrojených aktérů v selhávajících státech: Případ Hizballáhu. Mezinárodní vztahy, roč. 49, č. 2, s.. 38 GLEIS, J., L., BERTI, B. (2012). Hezbollah and Hamas. A Comparative Study. Baltimore: The Johns Hopkins University Press, s. 61-75. 
není v odborné literatuře věnována taková pozornost. ${ }^{6}$ Hlavním cílem článku je proto analyzovat energetickou strategii Hizballáhu zaměřenou na plyn a ropu v konfrontaci s Izraelem. Druhým záměrem je definovat hlavní cíle, motivy a metody této strategie libanonského islamistického hnutí Hizballáh. Dosažení těchto cílů bude realizováno prostrednictvím hledání odpovědí na několik dílčích otázek. (1) Jaký význam Hizballáh přisuzuje ve své strategii energetice obecně a konkrétně ve vztahu k Izraeli? (2) Jaké jsou hlavní cíle a motivy energetické strategie Hizballáhu v konfrontaci s Izraelem? (3) Jaké metody při tom Hizballáh používá? (4) Jaké jsou konkrétní projevy konfrontace hnutí Hizbaláh s Izraelem v oblasti energetiky?

$\checkmark$ metodologické rovině je článek založen na metodě případové studie, kterou lze chápat jako „detailní analýzu případu, který byl zvolen jako objekt výzkumu. Jejím cílem je poskytnout hluboké porozumění nebo př́činné vysvětlení. "7 Případem se v článku pak rozumí energetická strategie šíitského hnutí Hizballáh, přičemž případová studie rámuje konkrétní projevy konfrontace Hizballáhu vůči Izraeli.

Struktura článku je následující. V první části je definován teoretický rámec zaměřený na koncept terorismu a jeho konkrétního projevu v podobě teroristických útoků na energetický sektor. Dále je zmíněn význam energetického sektoru v šíitském islámu. Druhá a třetí část článku se věnuje analýze energetické strategie Hizballáhu a jejím konkrétním projevům v konfrontaci s Izraelem, jenž dle Hizballáhu zahájil produkci plynu ve sporných vodách východního Středomoří.

\section{TEORETICKÝ RÁMEC}

\subsection{Terorismus a jeho komunikační strategie}

Ještě na počátku devadesátých let byl terorismus považován nikoli za hrozbu, ale za riziko. Mezníkem zcela zásadního významu se staly teroristické útoky z 11. 9. 2001. Od té doby se o terorismu hovoří jako o závažné a naléhavé hrozbě a diskutuje se o možnostech, jak mu čelit. Autor v článku pak chápe terorismus jako

metodu použití síly či hrozby silou prováděná skrytými jednotlivci, skupinami nebo státem podporovanými aktéry. Akt násilí je zaměřen proti nevinným osobám nebo civilním cílům. Hlavním účelem teroristického aktu je vyvolat pocit strachu. Vedlejším účelem může být upoutání pozornosti, nebo získání dílčích výhod či ústupků ze strany atakovaného aktéra. Konečným cílem terorismu je politická změna. ${ }^{8}$

6 Jednou z mála výjimek je KARAGIANNIS, E. (2014). Comparative Islamist Perspectives on the Politics of Energy in the Middle East and Beyond. Studies in Conflict \& Terrorism, roč. 37, č. 8, s. 621.

7 KOŘAN, M. (2008). Jednoprípadová studie. In: DRULÁK, P. a kol. Jak zkoumat politiku. Praha: Portál, s 33.

8 Dále k tomu např́iklad srov. ŠEDIVÝ, J. (2003). Nové paradigma terorismu. Mezinárodní politika, roč. 27, č. 1, s. 4-5. 
Podle Jana Eichlera pak terorismus jako fenomén bezpečnostních vztahů je vyhraněnou formou komunikace s veřejností a má čtyři hlavní složky, kterými jsou

odesílatel poselství (transmitter), jímž je vždy terorista nebo teroristická organizace; terč úderů (target), jímž jsou mrtví a ranění lidé, kteří mají tu osudovou smůlu, že v nesprávnou chvíli jsou na nesprávném místě; poselství (message), určené vždy těm, kdo rozhodují o politice napadených států; reakce zastrašovaného (feed-back), jež je výsledkem politického vyhodnocování. ${ }^{9}$

Ve vztazích mezi těmito čtyřmi složkami platí jedna základní zásada: Ten, komu je poselství adresováno, tedy vydíraný a zastrašovaný subjekt, není obětí teroristického útoku. Žádná ze škod, kterou teroristé záměrně způsobují, není samoúčelná. Každý zabitý člověk, každá hmotná škoda jsou poselstvím a nástrojem nepřímého nátlaku na nejvyšší politické činitele. Od nich se očekává, že bud'to udělají to, co si přejí teroristé, nebo naopak přestanou dělat to, co teroristům vadí. ${ }^{10}$ Komunikační strategie představuje důležitý nástroj při zkoumání cílů a motivů jednotlivých aktivit Hizballáhu zaměřených na vyhrožování vojenským útokem na energetický sektor, čímž vysílá politickým představitelům Izraele jasnou zprávu/poselství.

\subsection{Teroristické útoky zaměřené na energetický sektor}

Koncept terorismu zaměřeného na sektor energetiky není striktně vymezen pouze na ozbrojené útoky proti elektrárnám, ropné a plynárenské infrastruktuře, ropným a plynovým polím, rafinériím, skladům s ropou a jiným energetickým sítím. Tento koncept zahrnuje i nezákonnou činnost prováděnou proti těmto zařízením, jako je krádež ropy z potrubí, vyhrožování teroristickým útokem, politické vydírání nebo financování a podpora skupin či hnutí, které výše zmíněné útoky provádějí. Všeobecně lze uvést, že terorismus zaměřený na energetický sektor je kriminální aktivita proti energetickým zařízením, jež způsobuje signifikantní ztráty. ${ }^{\mathbf{1 1}}$

Tamara Makarenko dělí útoky proti ropnému a plynárenskému průmyslu do sedmi kategorií, a to dle stupňů hrozby pro různé aktéry tohoto průmyslu. ${ }^{12}$ První, nejběžnější formou útoku, vzhledem k okamžitým dopadům a tím i způsobené nestabilitě, jsou bombové útoky na produktovody. Navíc způsobují velké škody národní ekonomice

9 Dále k tomu srov. EICHLER, J. (2009). Mezinárodní bezpečnost v době globalizace. Praha: Portal, 2, str. 161.

10 HENDERSON, H. Terrorism. Library in Book. Facts on File, 2001, s. 18.

11 Dále srov. KOKNAR, A., M. (2009). The Epidemic of Energy Terrorism. In: LUFT, G., KORIN, A. (Eds.). Energy Security Challenges for the 21st Century. California: ABC-CLIO, LLC, s. 18-30.

12 MAKARENKO, T. (2003). Terrorist Threat to Energy Infrastructure Increases. [on-line]. University of St. Andrews: Centre for the Study of Terrorism and Political Violence, June [cit. 2016-08-31]. Dostupné z: http://goo.gl/VBQrg4. 
a mohou způsobit ztráty na životech. Druhou formou, která neodmyslitelně patří k těmto útokům na produktovody, jsou sabotáže ropovodů a plynovodů. Jejich dominantním účelem je vytváření národních ekonomických ztát. $\mathrm{V}$ minulosti byly $\mathrm{k}$ třetí formě tj. k útokům na kanceláře ropných společností, použity různé taktiky. Jako takové byly tyto útoky spíše symbolické a využívány především jako propagandistické akce. Ještě méně běžné než bombové útoky na kanceláře a vedení jsou útoky proti ropným depům, benzinovým stanicím nebo samotným rafineriím, které představují čtvrtou formu. Pátou formou jsou únosy energetických zařízení spojené s braním rukojmích. Spolu s násilnými přepadeními těchto zařízení nejde o běžnou taktiku teroristických skupin, právě $z$ důvodů relativně vysokého stupně zabezpečení. ${ }^{13}$ Šestá a nejsmrtonosnější forma, ve smyslu potencionálních civilních ztrát, je prímý vojenský útok na personál ropných zařízení či závodů na zpracování plynu. Poslední a častěji se objevující formou jsou únosy zaměstnanců ropných firem teroristickými skupinami. S přihlédnutím $\mathrm{k}$ jednoduchosti provedení, únos pro výkupné je častou taktikou ze tří hlavních důvodů. Za prvé jako zdroj př́ijmů, za druhé jako protest proti korporátním taktikám energetických společností a za třetí pro rušení a ničení průzkumu a rozvoje ropných polí - čímž je to značně zatěžující pro národní finance. ${ }^{14}$

Teroristický útok cílený na energetický sektor představuje velkou hrozbu energetické bezpečnosti kdekoliv, kde k těmto útokům dochází nebo může dojít, přičemž možné ekonomické důsledky jsou potenciálně enormní ve vztahu k cílům útoků, jako jsou ropovody, depa, tankery, personál, rafinerie, LNG a ropné terminály atd. Při zranitelnosti této přepravní infrastruktury pak jakýkoliv výpadek v dodávkách nebo produkci může mít vážné dopady na energetických zdrojích závislé ekonomiky.

Ochrana klíčové energetické infrastruktury proti teroristickým útokům je nepochybně jednou z nejvyšších priorit bezpečnosti a prosperity. Mnohé země se zaměřují především na ochranu ropovodů, plynovodů, rafinerií a svých tankerů. Jiné země se soustřed'ují na ochranu vodních zdrojů a vodního potrubí. Všechny země však potřebují zásoby strategických surovin, jež nejsou nevyčerpatelné a ubývají. Dostat ropu a jiné suroviny z nedostupných míst a drsnějšího prostředí až ke koncovému uživateli nebo do bezpečného prostoru je stále těžší. Navíc teroristé si byli vždy velmi dobře vědomi důležitosti ropy a plynu jako politické a ekonomické potřeby, takže teroristické útoky na energetické cíle jsou pro ně velmi lákavé. ${ }^{15}$

Jinak řečeno, v základu terorismu cíleného proti sektoru energetiky jde o útoky zaměřené na energetickou infrastrukturu a průmysl, například elektrárny, rozvodné sítě či rafinérie, ropná a plynová pole, podniky na zpracování plynu apod., ale i nezákonnou

13 KOKNAR, A., M. (2009). The Epidemic of Energy Terrorism. In: LUFT, G., KORIN, A. (Eds.). Energy Security Challenges for the 21st Century. California: ABC-CLIO, LLC, s. 18-19.

14 MAKARENKO, T. (2003). Terrorist Threat to Energy Infrastructure Increases. [on-line]. University of St. Andrews: Centre for the Study of Terrorism and Political Violence, June [cit. 2016-08-31]. Dostupné z: http://goo.gl/VBQrg4.

15 KOKNAR, A., M. (2009). The Epidemic of Energy Terrorism. In: LUFT, G., KORIN, A. (Eds.). Energy Security Challenges for the 21st Century. Calífornia: ABC-CLIO, LLC, s. 20. 
činnost s tím spojenou s cílem destabilizovat vládu nebo i region. ${ }^{16}$ Kromě samotného přispění k politické a ekonomické nestabilitě může být cílení na energetický průmysl symbolem odporu vůči národním vládám a v neposlední řadě také jako způsob tlaku na cizí síly a mezinárodní korporace, jež mají strategický zájem v zemích produkujících ropu a plyn. To znamená, že útoky na energetický sektor představují v určitých případech důležitou součást strategie teroristických organizací v boji proti cizím mocnostem. Navíc teroristé čím dál častěji cílí na ropovody a plynovody jako možnost získávání ekonomických prostředků financující další teroristické operace nebo jako způsob, jak zvýšit svůj vliv mezi dalšími skupinami usilujícími o kontrolu. ${ }^{17} \mathrm{~V}$ tomto ohledu je pak potřeba se dále zaměřit na vztah energetiky a šíitského islámu, který je důležitý při zkoumání postoje Hizballáhu k energetice obecně a konkrétně k možným útokům a aktivitám cíleným na izraelský energetický sektor společně s doprovodnou kriminální činností.

\section{3 Šíitský islám a energetika}

Nicméně určitý problém při vymezení vztahu šíitského islámu a energetiky představuje skutečnost, že následná analýza role islámu v energetice reprezentuje pouze dílčí vzorec resp. pohled, byt' k tomu dochází u významných muslimských představitelů a myslitelů, kteří zásadním způsobem ovlivňují a formují postoj islámu k energetice. ${ }^{18}$ Druhý problém při zkoumání role islámu v energetice pak představuje skutečnost, že každá teroristická organizace včetně Hizballáhu může své rozhodování a jednání, zaměřené např́klad na útoky proti energetickému sektoru, ospravedlňovat vlastním výkladem islámu a jeho vztahem k energetice. Vzhledem k tomu, že Hizballáh je šíitské hnutí, další pozornost bude proto věnována především vztahu energetiky a šíitské větvi islámu, kde například šíitská škola Dža'fari zakazuje soukromé vlastnictví energetických zdrojů. Stejně tak šíitští kněží a intelektuálové diskutovali o významu ropného průmyslu.

Například irácký šíitský duchovní Muhammad Báqir as-Sadr ve své knize Naše ekonomika, klasifikuje minerály do dvou kategorií, a to na otevřené (například sůl či ropa), které nevyžadují dodatečnou práci a zpracování s cílem projevit svůj aktuální stav a na skryté (např. zlato a železo), jež vyžadují dodatečnou práci a rozvoj práce s cílem dosáhnout jejich potřebného stavu. Šíitský islám neuznává, aby si někdo přivlastňoval energetic-

16 Dále srov. GIROUX, Jennifer. (2009). Targeting Energy Infrastructure: Examining the Terrorist Threat in North Africa and its Broader Implications. [on-line]. Real Institute Ecano, February 13 [cit. 2016-06-31]. Dostupné z http://goo.gl/7jCjlK.

17 STEINHÄUSLER, Friedrich et al. (2008). Security Risks to the Oil and Gas Industry: Terrorist Capabilities. Strategic Insights, 2008, roč. 7, č. 1; MAKARENKO, Tamara. (2003). Terrorist Threat to Energy Infrastructure Increases. [on-line]. University of St. Andrews: Centre for the Study of Terrorism and Political Violence, June [cit. 2016-08-31]. Dostupné z http://goo.gl/VBQrg4; KOKNAR, A., M. (2009). The Epidemic of Energy Terrorism. In: LUFT, G., KORIN, A. (Eds.). Energy Security Challenges for the 21st Century. Calífornia: ABCCLIO, LLC, s. 20.

$18 \mathrm{~K}$ tomu dále srov. KARAGIANNIS, E. (2014). Comparative Islamist Perspectives on the Politics of Energy in the Middle East and Beyond. Studies in Conflict \& Terrorism, roč. 37, č. 8, s. 620. 
ké bohatostí, které tak nemůže být v soukromém vlastnictví, ale spadá do společného vlastnictví. ${ }^{19}$ Nicméně šíitský vůdce $M$. B. as-Sadr tvrdil, že islámské právo šaría umožňuje „podnikům získat takové množství minerálních zdrojů, které pokrývá individuální potřeby člověka“. ${ }^{20}$ Jinými slovy, Muhammad Báqir as-Sadr představil veřejný a soukromý sektor, kde společnost může pronajímat veřejnou půdu za účelem rozvoje a produkce zásob ropy a zemního plynu.

Vedle toho o významu ropy v íránských a blízkovýchodních záležitostech diskutoval také vůdce íránské islámské revoluce ajatolláh Rúholláh Chomejní. $V$ jedné ze svých přednášek nazvané Neslučitelnosti monarchie $s$ islámem, kterou $v 70$. letech minulého století prezentoval z exilu v jižním Iráku, se R. Chomejní ptal: „,...proč nikdo neprotestuje proti skutečnosti, že ropa patřící Íránu a islámu je prodávána do státu, který je ve válce $s$ muslimy? Proč je Izrael schopen získat vliv v záležitosti muslimské země?"21 A. Chomejní tímto způsobem kritizoval privilegovaný vztah Šáha Muhammada Rezi Pahlavího s židovským státem, který byl viděn většinou islamistů jako úhlavní nepřítel. ${ }^{22}$ Ještě důležitější je skutečnost, že $A$. Chomejní pochopil a zdủrazňoval strategický význam ropného sektoru pro přežití íránského režimu. V tomto ohledu A. Chomejní v listopadu 1978 uvedl, že „je povinností všech úředníků a pracovníků ropných firem zabránit vývozu ropy jako životně důležitého zdroje. Vědí tito pracovníci a úředníci, že kulky, které probodávají prsa našich drahých mladých lidí, které utápí v krvi naše muže, ženy a děti, jsou hrazeny z peněz získaných z ropy, kterou oni produkují?“.23

Ajatolláh Chomejní nebyl jediný íránský vůdce, který věnoval pozornost energetickým otázkám. Stejně tak Ize jmenovat napríklad íránského intelektuála Alího Šaríratího, který se zabýval vztahem islámu s marxismem, a zejména podivným spojením mezi energetickými surovinami (včetně ropy a zemního plynu) a západní sexuální etikou. Ali Šaríratí ve své přednášce nazvané Očekávání od muslimské ženy jasně uvedl, že „západní kolonialismus exportoval sexuální svobody do východních zemí výměnou za jejich energetické suroviny. Na místo ropy, diamantů, zlata, kaučuku apod., které Západ dovážel z východu, sem vyvážel freudismus a sexuální svobody“..24 Ve spisech A. Chomejního a A. Šaríratího je tak zcela patrná antiimperialistická nálada resp. postoj. Oba představitelé viděli ropu jako zdroj a přičinu cizího vměšování do íránských vnitřních záležitostí; zatímco Ajatolláh Chomejní se zaměřil na Izrael, Ali Šaríratí obviňoval Západ ze využívání/zneužívání zdrojů muslimů. ${ }^{25}$

19 AS-SADR, M., B. (1994). Our Economics, vol. 2. Tehran: World Organization for Islamic Services, s. 112. Tamtéž, s. 112. 
Podobný názor sdílel i přední libanonský šíitský ajatolláh Mohammad Hussein Fadlallah, jenž v ekonomické oblasti obvinil Západ ze zneužívání Blízkého východu jako oblasti s cenově dostupnými př́rodními zdroji, zejména ropy a plynu, a jako obrovského trhu, kam západní státy vyvážejí spotřebitelské produkty a zastaralou vojenskou techniku. ${ }^{\mathbf{2 6}}$ M. H. Fadlallah pak v tomto ohledu prijímá perspektivu neomarxistů a stoupenců teorie závislosti, kteří nevidí žádný nebo jen malý přínos pro ekonomiky zemí třetího světa z obchodních, energetických a hospodářských vazeb se Západem. ${ }^{27}$ Nicméně i přes tento postoj a nespočet odkazů na negativní ekonomické důsledky těsných hospodářských vazeb muslimských zemí se Západem, nepostupuje M. H. Fadlallah komplexní kritiku ekonomických vztahů Západu a států arabského a islámského světa. Fatwa a opakované výzvy k bojkotu amerických výrobků ze strany Mohammada Husseina Fadlallaha jsou pak důsledkem bezpodmínečné podpory Spojených států vůči Izraeli, a nikoliv proto, že by M. H. Fadlallah považoval hospodářské vztahy se Spojenými státy za vykořistovatelské. ${ }^{28}$

\section{ENERGETICKÁ STRATEGIE HIZBALLÁHU}

Hizballáh při plnění některých funkcí státu, včetně otázky zajištění nepřerušovaných a stabilních energetických dodávek, věnuje energetice zvýšenou pozornost. Zároveň energetika jako významná regionální otázka představuje pro Hizballáh důležitou součást jeho strategie, která nabízí príčinu konfrontace s úhlavním nepřítelem Izraelem. V tomto ohledu je hlavním zájmem energetické strategie Hizballáhu především snaha (a) zajistit energetickou bezpečnost Libanonu a (b) zahájit vlastní těžbu ropy a plynu na úkor Izraele, který má být poražen.

Libanon na svém území v současné době nemá žádné zásoby ropy ani plynu. Naopak země je silně závislá na dovozu energie k pokrytí domácí poptávky, a to zejména ropy a ropných produktů, které v roce 2014 představovaly více než 97 \% celkových dodávek primární energie v hodnotě $5,11 \mathrm{mld}$. dolarů, což představuje $11,4 \%$ libanonského HDP. ${ }^{29}$ Libanonská vláda chce proto do budoucna diverzifikovat energetický mix směrem od ropy k zemnímu plynu, ${ }^{30}$ aby posílila svou bezpečnost dodávek. Nicméně stejně jako u ropy bude muset Libanon prozatím importovat všechny své dodávky zemního plynu ze zahraničí.

Otázka zajištění a posílení energetické bezpečnosti je pak z pohledu Hizballáhu bezprostředně spojena se vztahem Libanonu k hlavnímu nepř́teli, a to Izraeli, který si údajně neoprávněně nárokuje libanonské nerostné bohatství ropy a zemního plynu ve východ-

26 Dále srov. BAROUDI, S., E. (2013). Islamist Perspectives on International Relations: The Discourse of Sayyid Muhammad Hussein Fadlallah (1935-2010). Middle Eastern Studie, roč. 49, č. 1, s. 120.

27 Tamtéž, s. 120.

28 Tamtéž, s. 120.

29 FATTOUH, B., EL-KATIRI, L. (2015). Lebanon: The Next Eastern Mediterranean Gas Producer? [on-line]. The German Marshall Fund of the United States, s. 1 [cit. 2017-06-28]. Dostupné z goo.gl/UHRHfp.

30 Zemní plyn není v současné době nijak výrazně zastoupen v energetickém mixu Libanonu. 
ních vodách Středozemního moře. Postoj Libanonu a Hizballáhu k Izraeli a této problematice explicitně vystihl novinový článek v deníku Al-Safir, který byl otištěn dne 8 . června 2010, několik dní po objevení zemního plynu v Izraeli, pod titulkem Izrael plánuje ukrást Libanonu offshorová plynová pole. Podle autora článku „Izraelci ignorují skutečnost, že zásoby plynu [v rámci pole Leviathan] se táhnou za rámec přibližných hranic jejich teritoriálních vod a podle jejich [vlastního] schématu zasahují do libanonských vod - něco, co představuje pro Libanon novou výzvu..."31 Článek pokračoval tvrzením, že většina vrtů Izraele na poli Leviathan byla mimo libanonské pobřeží, a dále předpověděl, že „oblast se brzy stane novou zónou konfliktu mezi Izraelem a Libanonem, který bude bránit svá práva na moři...".32

Tyto obavy potvrdil o tři roky později Hasan Nasralláh, když v jednom ze svých vystoupení zopakoval vyjádření libanonského ministra energetiky, který varoval, že „Izraelci jsou schopni položit potrubí a vzít naši - libanonskou - ropu a zemní plyn. Nicméně jako obvykle, nikdo [...] se ani nepohnul, zatímco Izraelci jsou schopni položit ruce na naši ropu, vodu, zemi, svrchovanost." ${ }^{\text {33 }}$ Hasan Nasralláh dále zdůraznil, že Libanon zůstává zemí pro své obyvatele, a že „naše vody zůstanou libanonské a naše ropné bohatství zůstává Libanonců. Dohodli jsme se, že nebudeme akceptovat, aby se někdo dotýkal suverenity naší země...." a „Izraelci vědí, že neexistuje žádná tolerance při překročení tohoto limitu....".34

Hizballáh pak vyvinul svoji energetickou strategii spoléhající na metodu „užití nebo hrozby násilí", která je založena na dvou pilírích, jež korespondují s hlavními cíli a motivy. Za prvé, Hizballáh vyhrožuje útokem na energetický sektor Izraele s cílem vojensky bránit libanonské energetické bohatství ropy a plynu před Izraelem a zajistit energetickou bezpečnost Libanonu, přičemž hlavním motivem je posílení stabilních dodávek a přistupu k energii, ale také požadavek na rozvoj vlastní produkce ropy a plynu. Za druhé, Hizballáh vyhrožuje vojenským útokem na energetický sektor Izraele s cílem poškodit svého neprítele a odradit Izrael od produkce plynu a ropy ve sporných oblastech východního Středomoří, přičemž hlavním motivem je konfrontace a usvědčení Izraele z agresivní energetické politiky vůči Libanonu, na kterou hnutí nebude váhat odpovědět vojenským útokem.

31 VARULKAR, H. (2010). Internal Conflict in Lebanon Over Control of Oil and Gas Resources. [online]. MEMRI, July 13, 2010 [cit. 2017-07-02]. Dostupné z goo.gl/Dde76y.

32 Tamtéž.

33 Srov. NASRALLÁH, H. (2013). Speech delivered by Hezbollah Secretary General Sayyed Hassan Nasrallah during the annual Iftar dinner of the "Islamic Resistance Support Organization. [on-line]. The Saker, July 22, 2013 [cit. 2017-07-02]. Dostupné z goo.gl/ElbnQc.

Tamtéž. 


\section{PŘíKLADY VYHROŽOVÁNÍ ÚTOKEM VU゚ČI IZRAELI ZE STRANY HIZBALLÁHU}

Tato část se následně věnuje konkrétním projevům resp. příkladům vyhrožování vojenským útokem vưči Izraeli ze strany Hizballáhu. Stejně tak je pozornost věnována cílům a motivům, které hnutí Hizballáh sleduje ve své strategii zaměřené na vyhrožování útokem na energetický sektor Izraele. Hlavním informačním zdrojem této činnosti libanonského hnutí Hizballáh jsou především projevy, vystoupení a rozhovory jeho generálního tajemníka Hasana Nasralláha. ${ }^{35}$

\subsection{Vyhrožování vojenským útokem na energetický sektor Izraele s cílem bránit libanonské energetické bohatství}

Před hrozbou ze strany Izraele vůči Libanonu varoval generální tajemník Hizballáhu již na první výročí „letní války“ v červenci 2006 v jednom ze svých projevů, kde zdůraznil, že Izrael je „nepř́telem, jehož povaha je agresivní s historickými ambicemi pro naši půdu, vodu a prírodní bohatstvi“. ${ }^{36}$ Skutečný význam tohoto varování před „agresí“ ze strany Izraele ve spojení s libanonským „prírodním bohatstvím“ se jasně projevil v posledních několika letech $v$ souvislosti s objevením několika velkých a středně velkých plynových polí v rámci naleziště Levanta, které je jednou ze sedmi pánví (nalezišt') v regionu východního Středomoří.

V rámci naleziště Levanta bylo v roce 2009 nejprve objeveno plynové pole Tamar s prokázanými rezervami zemního plynu kolem 283 mld. $\mathrm{m}^{3}$, které náleží Izraeli. Následně v listopadu 2010 americká firma Noble Energy, jako součást konsorcia zahrnujícího Delek Drilling, Avner Oil a Ratio Oil, objevila u izraelského pobřeží další plynové pole Leviathan s prokázanými rezervami plynu kolem $510 \mathrm{mld} . \mathrm{m}^{3}$. O krok později v listopadu 2011 pak firma Noble Energy oznámila další významný objev zemního plynu na mořském dně mezi Kyprem a Izraelem, a to pole Afrodita s odhadovanými rezervami kolem 102-170 miliard $\mathrm{m}^{3}$ zemního plynu. Celkové rezervy naleziště Levanta jsou odhadovány až na 3,4 bilionů $\mathrm{m}^{3}$ plynu ( $z$ toho 1,076 bil. $\mathrm{m}^{3}$ realizovaného plynu) a 1,7 miliardy barelů realizovatelné ropy. ${ }^{37}$

Libanonská výlučná ekonomická zóna (VEZ), která je součástí naleziště Levanta, by pak mohla obsahovat značný potenciál uhlovodíků, s počátečním odhadem až $850 \mathrm{mld}$. $\mathrm{m}^{3}$ plynu a 660 milionů barelů ropy. Přestože zatím nebyly realizovány žádné průzkumné

35 Autorovi se podařilo nashromáždit celkem 60 projevů generálního tajemníka H. Nastralláha, které se věnují energetické otázce, zejména ropě a zemního plynu.

36 NASRALLÁH, H. (2007). Al-Sayyed Nasrallah's speech at Rayah Stadium on Divine Victory Festival. [online]. The Saker, August 19, 2007 [cit. 2016-04-20]. Dostupné z goo.gl/PLf5o1.

37 Lebanon. [on-line]. The U. S. Energy Information Administration, March 2014 [cit. 2016-04-20]. Dostupné z https://www.eia.gov/beta/international/analysis.cfm?iso=LBN. 
vrty, libanonský ministr energetiky Gebran Bassil odhadl zásoby až na 2,7 bilionů $\mathrm{m}^{3}$ plynu a na 865 milionů barelů ropy. Nicméně norská společnost Spectrum, která v srpnu 2012 provedla v Libanonu první 3D seismický průzkum, odhadla vytěžitelné zásoby plynu v libanonských pobřežních vodách na 700 mld. $\mathrm{m}^{3}$ zemního plynu. ${ }^{38}$ Objevení těchto rezerv ropy a plynu a jejich produkce, která ovšem nezačne dříve než po roce 2020 , by mělo přispět ke snížení energetické závislosti a posílení energetické bezpečnosti Libanonu, což opakovaně uvítal H. Nasralláh v řadě svých projevů, kdy např́iklad uvedl, že „dnes má Libanon ve svých regionálních vodách národní bohatstvi“"39 a „dokonce říkají, že to naše bohatství, tedy libanonské - tj. ropa a zemní plyn, stojí miliardy dolarů“, 40 proto „následujíce naši chválu Alláhu, naše poděkování jsou určeny Tobě za objevení ropy a zemního plynu“, 41 které „,budeme využívat", 42 přičemž „Libanon je v současné době $v$ přechodu do nové fáze s prozkoumanými zásobami ropy a zemního plynu a naše země je nasměrována k prosperitě, zlepšení životních podmínek našich občanů...".43

Nicméně komerční produkce uhlovodíkových rezerv Libanonu čelí mnoha vnitřním a vnějším výzvám. V prvé řadě je problémem skutečnost, že energetický sektor zaměřený na těžbu ropy a plynu, stejně jako potřebný regulační a institucionální rámec, je v Libanonu stále v zárodku. Vedle toho Libanon až do roku 2005 neměl žádnou plynárenskou infrastrukturu. Za druhé, uzavřený politický systém Libanonu vedl k velkému zpoždění hydrokarbonového rozvoje a způsobil nestabilní regulační prostředí, přičemž země trpí slabou správou, rozsáhlou korupcí a špatným obchodním klimatem. ${ }^{44}$

Asi největší problém pak představuje nejasná demarkační linie mezi Libanonem a Izraelem ve Středozemním moři, kdy Libanon prohlašuje, že Izrael je v rozporu s jeho námořním právem. Jinak řečeno, Libanon tvrdí, že je zde sporná oblast o rozloze kolem 850 $\mathrm{km}^{2}$ zasahující do produkce izraelských plynových polí Tamara a Leviathan mezi Kyprem, Libanonem a Izraelem, která je součástí libanonské výlučné ekonomické zóny ${ }^{45}$. To potvrdil H. Nasralláh, podle kterého je „Libanon presvědčen, že tato oblast $\left(850 \mathrm{~km}^{2}\right)$ je

38 FATTOUH, B., EL-KATIRI, L. (2015). Lebanon: The Next Eastern Mediterranean Gas Producer? [on-line]. The German Marshall Fund of the United States, s. 1 [cit. 2017-06-28]. Dostupné z goo.gl/UHRHfp.

NASRALLÁH, H. (2011). "Dignity and Victory" Festival Speech by Hassan Nasrallah. [on-line]. Voltairnet. org, July 26, 2011[cit. 2016-04-20]. Dostupné z http://www.voltairenet.org/article170913.html.

40 Srov. NASRALLÁH, H. (2012). Speech of Hezbollah Secretary General Sayyed Hassan Nasrallah during the Iftar of the women's cadre in the Islamic Resistance Support Association. [on-line]. Voltairnet.org, August 10, 2012 [cit. 2016-04-20]. Dostupné z http://www.voltairenet.org/article179653.html.

41 Dále srov. NASRALLÁH, H (2013). Hassan Nasrallah's speech on The Injured Fighter Day. [on-line]. Voltairnet. org, June 17, 2013 [cit. 2016-04-20]. Dostupné z http://www.voltairenet.org/article179068.html.

42 NASRALLÁH, H. (2014). Full speech delivered by Hezbullah Secretary General Hassan Nasrallah on Friday August 15, 2014. [on-line]. The Saker, August 18, 2014 [cit. 2016-04-20]. Dostupné z http://vineyardsaker. blogspot.cz/2014/08/full-speech-delivered-by-hezbullah.html.

43 ABDUL-HUSSAIN, H. (2013). Loud and Unclear: Nasrallah sends out mixed messages on Syria. [on-line]. The Majala, May 15, 2013 [cit. 2016-04-20]. Dostupné z goo.gl/UE695D.

44 FATTOUH, B., EL-KATIRI, L. (2015). Lebanon: The Next Eastern Mediterranean Gas Producer? [on-line]. The German Marshall Fund of the United States, s. 2 [cit. 2017-06-28]. Dostupné z goo.gl/UHRHfp..

45 De Micco, Pasquale. The prospect of Eastern Mediterranean gas production: An alternative energy supplier for the EU? [on-line]. European Parlament, April 2014 [cit. 2017-06-28]. Dostupné z http://goo. gl/YWhVCT. 
jeho a Izrael zde nemá právo těžit ropu nebo zemní plyn ....".6 Zároveň skutečnost, že Libanon a Izrael jsou stále technicky ve válce a v současné době nemají diplomatické styky, znemožňuje vytyčení demarkační linie ve Středozemním moři mezi oběma státy.

$\checkmark$ roce 2011 proto obě země, Libanon i Izrael, předložily nároky na vymezení jejich VEZ k OSN. ${ }^{47}$ Ještě předtím v srpnu 2010 libanonský parlament schválil zákon č. 132 o ropných zdrojích v pobřežních vodách, který poskytuje právní a institucionální rámec pro průzkum a těžbu zdrojů ropy a plynu v pobřežních vodách Libanonu ve východním Středomoří a zpochybňuje vlastnická práva Izraele v rámci pole Leviathan a následně v červenci 2016 se libanonská vláda rozhodla vydávat povolení na průzkum ropy a plynu ve vodách, na něž si nárokuje právo Izrael. Takový vývoj by mohl změnit plány Izraele na rozvoj jeho plynových polí, či dokonce působit jako přičina vojenské konfrontace mezi Izraelem a Hizballáhem.

To již dřive potvrdil H. Nasralláh, podle kterého „se ropa a zemní plyn mohou stát bodem konfliktu mezi Libanonem a jeho nepř́telem [Izraelem] zejména při vymezení sporné oblasti“, proto je otázkou „jaké jsou pro Libanon záruky, že v budoucnosti získá vlastní zemní plyn a ropu? A [...] budeme mít skutečně prospěch z dostupných schopností a kapacit na úrovni zemního plynu a ropy? To jsou důležité otázky, ale je tu ještě jedna důležitá otázka“, 48 a to „Jak bychom měli bránit naši ropu a zemní plyn? Poezií? Transparenty?“. ${ }^{99} \mathrm{Na}$ tuto otázku pak jasně odpověděl náměstek generálního tajemníka Naim Kassim, dle kterého „Libanon [Hizballáh] bude stát na stráži s cílem chránit svá práva bez ohledu na cenu“.50

Kromě toho Hizballáh odmítl uznat dohodu se sousedním Kyprem podepsanou bývalým premiérem Fouadem Siniorou v lednu 2007, která vytyčuje libanonsko-kyperskou námořní hranici ve smyslu výlučné ekonomické zóny. $V$ návaznosti na izraelské objevy plynu pak tato otázka získala nový politický význam, když například v říjnu 2012 úředník Hizballáhu uvedl, že „dohoda mezi Libanonem a Kyprem je anulována, protože libanonská strana, která ji podepsala, překročila svoje oficiální kapacity [...] Moře, stejně jako země jsou stoprocentním legitimním právem Libanonu a budeme je bránit celou svou silou“.51 Ve skutečnosti Hizballáh nejenom oponoval libanonsko-kyperské vymezující dohodě, ale byl také znepokojen rychlým zlepšením vzájemných vztahů mezi Kyprem

46 Dále srov. NASRALLÁH, H. (2011). "Dignity and Victory" Festival Speech by Hassan Nasrallah. [on-line]. Voltairnet.org, July 26, 2011[cit. 2017-06-28]. Dostupné z http://www.voltairenet.org/article170913.html.

47 To ovšem vyvolává problém neslučitelnosti vyplývající z dohod o námořní hranici, které obě země vyjednaly s Kyprem v roce 2007 resp. 2010. Rozpor mezi těmito dohodami má za následek vznik sporné oblasti, kde se překrývají izraelská, a libanonská VEZ.

48 NASRALLÁH, H. (2012). Speech of Hezbollah Secretary General Sayyed Hassan Nasrallah during the Iftar of the women's cadre in the Islamic Resistance Support Association. [on-line]. Voltairnet.org, August 10, 2012 [cit. 2016-04-20]. Dostupné z http://www.voltairenet.org/article179653.html.

49 NASRALLÁH, H. (2011). Speech of Hezbollah Secretary General of Hassan Nasrallah's on March 192011. [on-line]. Youtube.com, March 22, 2011 [cit. 2016-04-20]. Dostupné z goo.gl/7ShhSp.

50 KARAGIANNIS, E. (2014). Comparative Islamist Perspectives on the Politics of Energy in the Middle East and Beyond. Studies in Conflict \& Terrorism, roč. 37, č. 8, s. 622.

51 CHOUFI, F. (2012). Hezbollah: Siniora Gave Away Lebanese Oil. [on-line]. Al Akhbar, October 27, 2012 [cit. 2016-04-20]. Dostupné z http://english.al-akhbar.com/node/13139. 
a Izraelem a neposlední řadě byl překvapen zjištěním, že Kypr po desetiletí sledoval prolibanonskou a propalestinskou politiku.

\subsection{Vyhrožování vojenským útokem na energetický sektor Izraele s cílem poškodit neprítele a odradit ho od produkce plynu a ropy}

Energetická otázka spojená s objevením nových zásob ropy a zemního plynu ve východním Středomoří tak představuje novou spornou otázku v izraelsko-libanonských vztazích, kterou Hizballáh využil ke konfrontaci s Izraelem. Tvrzením, že Izrael krade libanonské zásoby plynu a ropy, libanonské hnutí Hizballáh ve skutečnosti démonizuje svého soupeře, který je obviněn z energetického imperialismu. Nicméně takové tvrzení dobře rezonuje s názory mnoha Libanonců, kteří vnímají Izrael jako agresivního souseda, který nerespektuje územní celistvost Libanonu. V tomto ohledu může šíitské hnutí Hizballáh samo sebe prezentovat jako skutečně vlasteneckou organizaci, která bojuje proti Izraeli ve jménu národní nezávislosti a suverenity. Ještě důležitější je skutečnost, že otázka energie může přetvořit obraz hnutí Hizballáh v okamžiku, kdy čelí silné kritice za svoji účast v syrské občanské válce.

Tento postoj Libanonu vưči Izraeli zopakoval Hasan Nasralláh v televizním projevu na konci července 2011 u príležitosti pátého výročí „letní války“ v roce 2006. Podle H. Nasralláha, „[Libanon] nikdy neuzná právo Izraele na jeho existenci, stejně jako právo na těžbu ropy a plynu v libanonských a palestinských vodách“. ${ }^{2}$ Zároveň H. Nasralláh neváhal pohrozit Izraeli útokem proti jeho energetické infrastruktuře, když jasně zdůraznil, že „jsme varovali Izrael před rozšiřováním jeho vlivu v této oblasti a loupením libanonských zdrojů z libanonských vod“, přičemž uvedl, že „ten, kdo poškozuje naše budoucí ropná zařizení v libanonských teritoriálních vodách, musí počítat s tím, že také jeho vlastní zařízení budou napadena“. ${ }^{33}$ Podobně se generální tajemník Hizballáhu vyjádřil i o rok později v jednom ze svých projevů v srpnu 2012, kde opět nepřímo pohrozil Izraeli vojenskou odpovědí v prípadě, pokud se pokusí těžit zemní plyn a ropu v libanonských teritoriálních vodách. ${ }^{54}$ Současně s tím ovšem Hasan Nasralláh připustil, že Hizballáh za stávající situace není schopen efektivně bránit libanonské prírodní bohatství proti Izraeli. Vůdce libanonského hnutí Hizballáh Hasan Nasralláh pak ve svém projevu zdůraznil:

52 NASRALLÁH, H. (2011)."Dignity and Victory" Festival Speech by Hassan Nasrallah. [on-line]. Voltairnet. org, July 26, 2011[cit. 2016-04-20]. Dostupné z http://www.voltairenet.org/article170913.html.

53

54 
„Jaké jsou záruky, že Izrael nenapadne Libanon a jak jej můžeme odradit od útoku na Libanon [a krádeže našeho nerostného bohatství]? Neexistuje žádná odpověd'. Je zde jen jedna odpověd': vyzbrojit armádu. Shodli jsme se na tom. Pojd'me vyzbrojit armádu. Nicméně tato armáda není schopna tvořit odstrašující sílu a [bránit naši ropu a zemní plyn]. Její síla musí být přinejmenším stejná jako u Izraele. Musíme vlastnit nejsilnější letectvo v regionu, jako je například izraelské letectvo, a musíme mít armádu podobnou izraelské armádě. To znamená vytvořit jakousi rovnováhu, s jejiž pomocí bychom mohli chránit Libanon a zároveň dosáhnout odstrašující vojenskou sílu v kvalitě, kvantitě a schopnostech." ${ }^{\text {55 }}$

Ve skutečnosti hnutí Hizballáh disponuje vlastní rozsáhlou vojenskou kapacitou, pokud by se rozhodl $\mathrm{k}$ útokům proti izraelským plošinám na těžbu zemního plynu v pobřežních vodách východní části Středozemního moře. To mimo jiné potvrdila válka v roce 2006, která jasně ukázala, že hnutí Hizballáh drží například rakety C-802 s doletem kolem 120 km k ničení lodí, stejně jako balistické rakety Zelzal-2 s doletem od 200 do $400 \mathrm{~km} .{ }^{56}$ Vedle toho má libanonské hnutí ve své výzbroji také velice sofistikované nadzvukové rakety Onyx pro boj s plavidly, které hnutí Hizballáh s největší pravděpodobností získalo ze Sýrie, jíž je naopak dodala Ruská federace. ${ }^{57}$ Rakety Onyx jsou schopny zasáhnout plošiny na těžbu zemního plynu a ohromit izraelské prístavy v Haifě a Ašdodu. ${ }^{58}$ To potvrdil Hasan Nasralláh v jednom ze svých projevů v lednu 2016, když varoval Izrael před útokem na skladovací nádrže plynu amoniak v př́stavu Haifa. Podle Hasana Nasralláha:

\begin{abstract}
„Není třeba se obávat války s Izraelem, protože po první a druhé válce s Libanonem se Izrael rozhodl vést válku, pouze pokud je zaručeno rychlé vítězství. Když Izrael ví, že je zde síla Libanonu, která mu může zabránit v dosažení rychlého vítězství, nebude se angažovat v takové válce. [...] Hizballáh má několik raket, jež jsou schopny způsobit katastrofu ve městě Haifa, která by byla ekvivalentem útoku ,atomové bomby'. Izraelští experti ríkají, že obyvatelé Haify se obávají smrtícího útoku na zásobníky čpavku, které obsahují více než 15000 tun tohoto plynu.... To by vedlo ke smrti desítek tisíc obyvatel a až 800000 Izraelců by mohlo být postiženo..." ${ }^{59}$
\end{abstract}

55 NASRALLÁH, H. (2012). Speech of Hezbollah Secretary General Sayyed Hassan Nasrallah during the Iftar of the women's cadre in the Islamic Resistance Support Association. [on-line]. Voltairnet.org, August 10, 2012 [cit. 2016-04-20]. Dostupné z http://www.voltairenet.org/article179653.html.

56 KARAGIANNIS, E. (2014). Comparative Islamist Perspectives on the Politics of Energy in the Middle East and Beyond. Studies in Conflict \& Terrorism, roč. 37, č. 8, s. 623.

57 Vedle toho se spekuluje, že by Hizballáh mohl získat resp. vlastnit také ruské letecké protiletadlové rakety Jachont $s$ doletem až $300 \mathrm{~km}$, čímž by mohl potenciálně ohrožovat izraelská plynová pole ve Středozemním moři a schopnost izraelského námořnictva působit v oblasti. Hezbollah said to have obtained 'game-changing' anti-ship missiles. [on-line]. The Times of Israel, February 19, 2017 [cit. 201704-20]. Dostupné z goo.gl/YqoFAC.

58 ZITUN, Y. (2016). ,Hezbollah is getting the most sophisticated Russian weapons. [on-line]. Israel News, January 20, 2016 [cit. 2016-04-20]. Dostupné z goo.gl/bxzhj.

59 NASRALLÁH, H. (2016). Sayyed Nasrallah Warns 'Israel' of 3rd Lebanon War, and to Al-Saud: Ground Intervention in Syria to End You. [on-line]. ABNA24.com, February 17, 2016 [cit. 2016-04-20]. Dostupné z goo.gl/zOWr3X. 
Hrozbu útoku na skladovací nádrže plynu amoniak v přístavu Haifa zopakoval Hasan Nasralláh znovu v polovině února 2017. Vedle toho ovšem vůdce Hizballáhu pohrozil raketovým útokem na izraelské jaderné reaktory v jižním městě Dimona. Hasan Nasralláh pak vyzval „Izrael nejen k evakuaci nádrže z Haify, ale i k demontáži jaderného zařízení Dimona“ a zároveň varoval, že „izraelské jaderné zbraně, které představují hrozbu pro celý region, proměníme v hrozbu pro Izrael“. ${ }^{\prime \prime 0}$

Libanonské šíitské hnutí Hizballáh tak přijalo jako součást své strategie energetický program, který se zaměřuje na zásoby plynu a ropy u pobřeží Libanonu. To znamená, že libanonské hnutí Hizballáh využívá otázku pobřežních plynových polí k mobilizaci široké podpory pro jeho boj proti Izraeli, kterého se snaží odradit od produkce plynu ve sporných vodách východního Středomoří a současně s tím poskytuje vizi transformace zadlužené ekonomiky Libanonu.

\section{ZÁVĚR}

Vzhledem ke stále rostoucímu politickému a hospodářskému významu ropy a zemního plynu ve světě, převzala energetickou otázku v průběhu několika posledních desetiletí do svého diskurzu většina islamistických organizací a hnutí, které současně s tím inkorporovaly energetickou agendu do svých strategií. Př́kladem může být al-Káida, Tálibán, Islámský stát, ale i libanonské (politicky šíitské) sociální hnutí Hizballáh, jež disponuje vlastními ozbrojenými složkami a využívá i teroristické metody boje.

Pro hnutí Hizballáh, které má atributy státního aktéra a je odpovědné svým voličům, představuje energetická agenda dlouhodobě důležité lokální téma, jež se stalo součástí jeho strategie. Na jednu stranu pak Hizballáh v tomto ohledu spoléhá na islámské zdroje, aby si zajistil legitimizaci svých kampaní a zájmů, které jsou běžně podporovány verši z Koránu. Stejně tak Hizballáh jedná v souladu s šítským islámem a názory některých jeho představitelů a myslitelů, jako například vůdce íránské revoluce ajatolláha R. Chomejního, A. Šarí atího či ajatolláha M. H. Fadlallaha. Zároveň tvorba a podpora energetické agendy ze strany Hizballáhu slouží jako cenná politická zbraň a nabízí příčinu konfrontace vưči úhlavnímu nepř́teli tj. Izraeli. Na druhou stranu představa hnutí Hizballáh o vlastnictví zásob plynu a ropy vychází spíše z pragmatického předpokladu, že tyto zdroje by mohly mít pozitivní vliv na domácí i zahraniční politiku, než šíitským islámem ovlivněného požadavku, že skupina by měla chránit majetek ummy. $V$ tomto př́padě se Hizballáh dostává do rozporu s názory například šíitské školy Dža'fari či iráckého šíitského duchovního M. B. as-Sadra. Hnutí Hizballáh realizuje svoji energetickou strategii pomocí metody „hrozby nebo užití síly“ a dívá se na násilí, jako legitimní způsob k dosažení cílů v oblasti energetiky. Následující tabulka č. 1 shrnuje hlavní rysy činnosti Hizballáhu v sektoru energetiky.

60 Hezbollah chief threatens Israel's Dimona nuclear reactor. [on-line]. The Times of Israel, February 16, 2017 [cit. 2017-04-20]. Dostupné z goo.gl/ALmtvt. 


\begin{tabular}{|c|c|c|c|c|}
\hline \multirow{2}{*}{$\begin{array}{l}\text { Teroristická } \\
\text { a militantní } \\
\text { organizace či } \\
\text { hnutí }\end{array}$} & \multicolumn{4}{|c|}{ Kritéria } \\
\hline & $\begin{array}{c}\text { Charakteristika } \\
\text { organizace }\end{array}$ & $\begin{array}{c}\text { Postoj organizace k } \\
\text { energetice a zájmy energetické } \\
\text { strategie }\end{array}$ & $\begin{array}{l}\text { Vliv islámu na roz- } \\
\text { hodování a jednání } \\
\text { organizace }\end{array}$ & $\begin{array}{l}\text { Metody energetic- } \\
\text { ké strategie }\end{array}$ \\
\hline Hizballáh & $\begin{array}{l}\text { - Libanonské isla- } \\
\text { mistické (politicky } \\
\text { šíitské) sociální hnu- } \\
\text { tí, které disponuje } \\
\text { vlastními ozbroje- } \\
\text { nými složkami a vy- } \\
\text { užívá i teroristické } \\
\text { metody boje. }\end{array}$ & $\begin{array}{l}\text { - Energetika jako významná regio- } \\
\text { nální otázka představuje důležitou } \\
\text { součást strategie, která nabízí } \\
\text { příčinu konfrontace s Izraelem. } \\
\text { - Hlavním zájmem energetické } \\
\text { strategie je zajistit energetickou } \\
\text { bezpečnost Libanonu a zahájit } \\
\text { vlastní těžbu ropy a plynu na úkor } \\
\text { Izraele, který má být poražen. }\end{array}$ & $\begin{array}{l}\text { - Na jednu stranu } \\
\text { dochází při jednání } \\
\text { a rozhodování ke zneu- } \\
\text { žívání šíitského islámu. } \\
\text { - Na druhou stranu } \\
\text { dochází k rozhodování } \\
\text { a jednání ve jménu } \\
\text { šíitského islámu. }\end{array}$ & $\begin{array}{l}\text { Užití násilí } \\
\text { nebo hrozba } \\
\text { násilím }\end{array}$ \\
\hline
\end{tabular}

Tabulka č. 1: Hlavní rysy činnosti Hizballáhu v sektoru energetiky

Hlavním zájmem energetické strategie Hizballáhu je zajistit energetickou bezpečnost Libanonu a zahájit vlastní těžbu ropy a plynu na úkor Izraele, který má být poražen. $V$ toto ohledu pak Hizballáh vyhrožuje vojenským útokem na ropná a plynová pole a energetická zařízení Izraele s cílem bránit potenciální libanonská naleziště ropy a plynu ve východním Středomoří před Izraelem a zajistit energetickou bezpečnost Libanonu. Hlavním motivem tohoto vyhrožování je především snaha o zabezpečení stabilních a nepřerušovaných dodávek ropy, plynu, ale i elektřiny a posílení přístupu k energiím, ale také požadavkem na rozvoj vlastní produkce ropy a plynu v libanonských vodách. Zároveň hnutí Hizballáh vyhrožuje vojenským útokem na plynová a ropná pole v izraelských vodách a na energetickou infrastrukturu Izraele s cílem poškodit svého hlavního nepřítele a odradit Izrael od těžby a produkce plynu a ropy ve sporných oblastech východního Středomoří. Hlavním motivem vyhrožování je zejména obvinění a usvědčení Izraele z agresivní energetické politiky vưči Libanonu, na kterou hnutí nebude váhat odpovědět vojenským útokem.

\begin{tabular}{|c|c|c|c|}
\hline $\begin{array}{c}\text { Cíle } \\
\text { vyhrožování }\end{array}$ & Motivace vyhrožování & $\begin{array}{l}\text { Příklady } \\
\text { Vyhrožování }\end{array}$ & $\begin{array}{l}\text { Implikace vyhrožování na energetickou } \\
\text { bezpečnost }\end{array}$ \\
\hline $\begin{array}{l}\text { Vyhrožování vo- } \\
\text { jenským útokem } \\
\text { na energetický sektor } \\
\text { Izraele s cílem: } \\
\text { 1) vojensky bránit } \\
\text { libanonské energetické } \\
\text { bohatství před Izra- } \\
\text { elem a zajistit ener- } \\
\text { getickou bezpečnost } \\
\text { Libanonu; } \\
\text { 2) poškodit svého ne- } \\
\text { přítele a odradit Izrael } \\
\text { od produkce plynu } \\
\text { a ropy ve sporných } \\
\text { oblastech východního } \\
\text { Středomoří. }\end{array}$ & $\begin{array}{l}\text { Hlavním motivem } \\
\text { vyhrožování je: } \\
\text { 1) posílení stabilních } \\
\text { dodávek a přístupu } \\
\text { k energii, ale také } \\
\text { požadavek na rozvoj } \\
\text { vlastní produkce ropy } \\
\text { a zemního plynu; } \\
\text { 2) je konfrontace } \\
\text { a obvinění Izraele } \\
\text { z agresivní energetické } \\
\text { politiky vůči Libanonu, } \\
\text { na kterou hnutí nebu- } \\
\text { de váhat odpovědět } \\
\text { vojenským útokem. }\end{array}$ & $\begin{array}{l}\text { Hasan Nasralláh a Naim } \\
\text { Kassim opakovaně } \\
\text { vyhrožovali vojenským } \\
\text { útokem proti ropným } \\
\text { a plynovým polím } \\
\text { a energetické infrastruk- } \\
\text { tuře Izraele. } \\
\text { - Zatím nejvážnější inci- } \\
\text { dent se odehrál v lednu } \\
2016, \text { kdy H. Nasralláh } \\
\text { vyhrožoval útokem } \\
\text { na skladovací nádrže } \\
\text { plynu amoniak v přístavu } \\
\text { Haifa, po kterém by } \\
\text { mohlo zemřít až } 800000 \\
\text { Izraelců. }\end{array}$ & $\begin{array}{l}\text { - V současné době neexistují žádné impli- } \\
\text { kace pro energetickou bezpečnost a eko- } \\
\text { nomiku Západu, ani Izraele, který je pouze } \\
\text { nucen vynaložit další finanční prostředky } \\
\text { na nákup vojenských prostředkú a do zbro- } \\
\text { jení k ochraně ropných a plynových polí } \\
\text { v izraelských vodách Středozemního moře } \\
\text { a infrastruktury na území Izraele. } \\
\text { - V prýípadě, že by Hizballáh zaútočil a zničil } \\
\text { těžební zařízení na moři nebo poškodil } \\
\text { energetickou infrastrukturu Izraele, dopady } \\
\text { na energetickou a ekonomickou bezpečnost } \\
\text { se budou odvíjet od rozsahu a velikosti } \\
\text { vzniklé škody. } \\
\text { - Západ by nebyl nijak zasažen, protože } \\
\text { nedováži plyn či ropu z Izraele, pouze by to } \\
\text { negativně ovlivnilo rozhodování o budoucím } \\
\text { exportu zemního plynu z Izraele do EU. }\end{array}$ \\
\hline
\end{tabular}

Tabulka č. 2: Hlavní cíle, motivy a příklady vyhrožování a jejich implikace pro energetickou bezpečnost ze strany Hizballáhu 
Hizballáh zatím neuskutečnil žádný útok na izraelskou plynárenskou infrastrukturu a dává si pozor, aby neotevřel druhou frontu proti Izraeli kvůli zásobám plynu v pobřežních vodách Středozemního moře $v$ době, kdy libanonská společnost je silně zatížená syrskou občanskou válkou. V současné době proto neexistují zatím žádné implikace pro energetickou bezpečnost a ekonomiku Západu tj. Evropské unie a Spojených států, ani Izraele, který je pouze nucen vynaložit další finanční prostředky na nákup vojenských prostředků a techniky k ochraně a obraně ropných a plynových polí v izraelských vodách Středozemního moře a energetické infrastruktury na území Izraele.

V př́ipadě, že by Hizballáh zaútočil a zničil těžební zařízení na moři či poškodil energetickou infrastrukturu Izraele, dopady na energetickou a ekonomickou bezpečnost se budou odvíjet od rozsahu a velikosti vzniklé škody. Naproti tomu energetická a ekonomická bezpečnost Západu by nebyla nijak zasažena, protože ani USA, ani EU nedováži v současné době zemní plyn či ropu z Izraele, pouze by to negativně ovlivnilo rozhodování o budoucím exportu plynu z Izraele do EU bud' prostřednictvím plánovaného plynovodu East Med Gas Pipeline s roční kapacitou kolem 30-40 miliard m³ plynu, který by vedl východním Středomořím z Izraele přes Kypr do Řecka, kde by se následně napojil na plánovaný Transadriatický plynovod (TAP) nebo ve formě LNG pomocí tankerů s roční kapacitou kolem 7 mld. $\mathrm{m}^{3}$ plynu ze společného izraelsko-kyperského LNG terminálu v prístavu Vassilikos ${ }^{61}$ a zároveň zvýšilo náklady diversifikaci přepravních tras EU. Tabulka č. 2 pak shrnuje hlavní cíle, motivy a příklady vyhrožování a jejich implikace na energetickou bezpečnost ze strany libanonského hnutí Hizballáh.

Autor: $\quad$ Mgr. et Mgr. Lukáš Tichý, Ph.D. Narozen 1982. Pracuje jako výzkumný pracovník na Ústavu mezinárodních vztahů Praha. Zabývá problematikou energetické bezpečnosti, zahraniční a bezpečnostní politikou EU a Ruska a teoriemi mezinárodních vztahů. Publikoval řadu článků v tuzemských a zahraničních odborných časopisech, sbornících a monografiích.

Jak citovat: TICHÝ, Lukáš. Energetika jako strategický nástroj hnutí Hizballáh v konfrontaci s Izraelem. Vojenské rozhledy. 2017, 26 (3), 14-30. DOI: 10.3849/23362995.26.2017.03.014-030. ISSN 1210-3292 (print), 2336-2995 (on-line). Available at: www.vojenskerozhledy.cz

61 De MICCO, Pasquale. 2014. The prospect of Eastern Mediterranean gas production: An alternative energy supplier for the EU? [on-line]. European Parlament, April [cit. 2016-04-20]. Dostupné z http://goo.gl/ YWhVCT. 


\section{Aktuální úkoly kybernetické obrany rezortu Ministerstva obrany}

\section{Recent Objectives of Cyber Defence in the Department of Defence}

\section{Miroslav Feix, Dalibor Procházka}

Abstrakt: Článek se zabývá problematikou kybernetické bezpečnosti, kybernetické obrany a operací v kybernetickém prostoru s důrazem na rezort obrany. V článku je provedena analýza úkolů kybernetické obrany vyplývající ze strategických dokumentů České republiky, NATO a Evropské unie a role jednotlivých subjektů, které se na zajištění kybernetické obraně či bezpečností podílejí. Jako další zdroj úkolů jsou vytvořeny čtyři scénáře, které popisují možné situace, které budou vyžadovat schopnosti kybernetické obrany. Tato analýza je předpokladem pro stanovení požadovaných schopností a návrh řešení, jak rozdělit role, odpovědnosti a požadované schopnosti.

Abstract: The paper deals with cyber security, cyber defence and operations in cyber space focusing on the department of defence. Tasks implied from the Czech Republic's, NATO's and European Union strategic documents and roles of participating subjects have been analysed. Four scenarios as another source of identified tasks were created and used to describe possible situations requiring cyber defence capabilities. The presented analysis is a prerequisite for specifying required capabilities, and a proposal how to assign roles, responsibilities and required capabilities.

Klíčová slova: Kybernetický prostor; kybernetická bezpečnost; kybernetická obrana; kybernetické operace

Keywords: Cyberspace; Cyber Security; Cyber Defence; Cyber Operations 


\section{ÚVOD}

V odborné i laické debatě je stále častěji možné se setkat s pojmy, jako jsou kyberprostor, kybernetické hrozby, kybernetická kriminalita, kybernetická bezpečnost a s ní spojená kybernetická obrana. Vzhledem k tomu, jak často se modifikující (i samostatně stojící) termín „kybernetická obrana“ používá, je vhodné si ho přesněji vymezit, pochopit a používat $v$ odborné bezpečnostně-obranné debatě. Je přijat a novelizován zákon o kybernetické bezpečnosti, zajištění kybernetické bezpečnosti a obrany se dostává mezi strategické zájmy České republiky. $V$ poslanecké sněmovně je připravena novela zákona o Vojenském zpravodajství, v jeho rámci i novela zákona o obraně. NATO vyhlašuje kybernetický prostor jako další plánovací a operační doménu na úrovni domén země, vzduch, moře a vesmír. Dále NATO prohlašuje, že napadení v kybernetickém prostoru je napadení podle článku 5 Washingtonské smlouvy a zakládá právo na aktivaci společné obrany. Je třeba kriticky zhodnotit, zda jsou bezpečnostní a obranný systém ČR, Ministerstvo obrany a ozbrojené síly připraveny čelit výzvám budoucího prostředí.

Článek se zabývá problematiku kybernetické bezpečnosti, kybernetické obrany a operací v kybernetickém prostoru se zaměřením na rezort obrany České republiky. Dưraz je kladen na aktuálnost a důležitost kybernetického prostoru v rámci současného a budoucího operačního prostředí. Metodou analýzy, faktorové analýzy PESTLE a metodou scénářů jsou identifikovány úkoly kybernetické obrany, $\mathrm{k}$ jejichž plnění bude muset rezort obrany disponovat odpovídajícími schopnostmi.

Chápání kybernetické obrany je v České republice, a především v rezortu obrany, nejednotné. Armáda nemá doktrínu pro vedení operací v kybernetickém prostoru ani odborníky, kteří by se problematice systematicky věnovali.

Ohrožení České republiky v kybernetickém prostoru není hypotetickou hrozbou. Včas porozumět, identifkovat a vhodně eliminovat ohrožení v době míru, či umět využít pro vedení operací i všechny operační domény $v$ době vedení bojové činnosti je pro zajištění životních a strategických zájmů ČR klíčové. Článek shrnuje část výsledků dosažených při zpracování závěrečné práce $v$ kurzu generálního štábu, diskutuje úkoly, které stojí v oblasti kybernetické obrany. Výsledky analýzy jsou použity k odvození požadovaných schopností a $\mathrm{k}$ návrhu jejich přiřazení nositelům, ale návrh řešení je mimo záměr tohoto článku.

\section{POUŽITÉ METODY}

Metoda analýzy byla aplikována na dostupné prameny, které zahrnují zákonné, koncepční a doktrinální dokumenty ČR, Severoatlantické aliance i Spojených států amerických, odborné publikace a články v médiích. Závěry byly konzultovány s vybranými odborníky zabývajícími se problematikou bezpečnosti a obrany v kyberprostoru.

Nejprve je analyzován současný stav a úkoly kybernetické bezpečnosti a kybernetické obrany v České republice získané především z analýzy oficiálních dokumentů. Na analýzu navazují další úkoly potřebné pro stanovení požadavků na schopnosti. $K$ tomu je využi- 
ta analýza trendů a implikací k charakteristice budoucího operačního prostředí a jsou zpracovány čtyři scénáře pokrývající některé možné situace působení v kybernetickém prostoru, ze kterých úkoly vyplývají.

Pro zpracování analýzy trendů je využita faktorová analýza PESTLE. Trendy jsou analyzovány v šesti oblastech, politické, ekonomické, sociální, technologické, právní a environmentální. Hlavním zdrojem informací o trendech a budoucím prostredí byly analytické dokumenty NATO a Spojených států amerických. Možná budoucnost je dále zpracována v jednotlivých scénárích. Scénáře jsou vhodnou prognostickou metodou pro porozumění a vizualizaci možné budoucnosti. $V$ České republice je metoda scénářu pro potřeby obrany a ozbrojených sil poněkud zanedbávána, pritom vhodně zvolený scénář umožňuje popsat budoucí vývoj a možné budoucí situace. Zpřesní potenciální cíle, efekty a úkoly a následně lze odvodit požadavky na schopnosti potřebné k zvládnutí situace. Pro přesnější zpracování kontextu je použita systémová analýza PMESII, která je založena na rozpracování operačních proměnných v oblastech politické, vojenské, ekonomické, sociální, informační a infrastrukturní, což umožňuje popsat situaci ve své komplexnosti. Zdroje úkolů jsou znázorněny na obrázku č. 1.

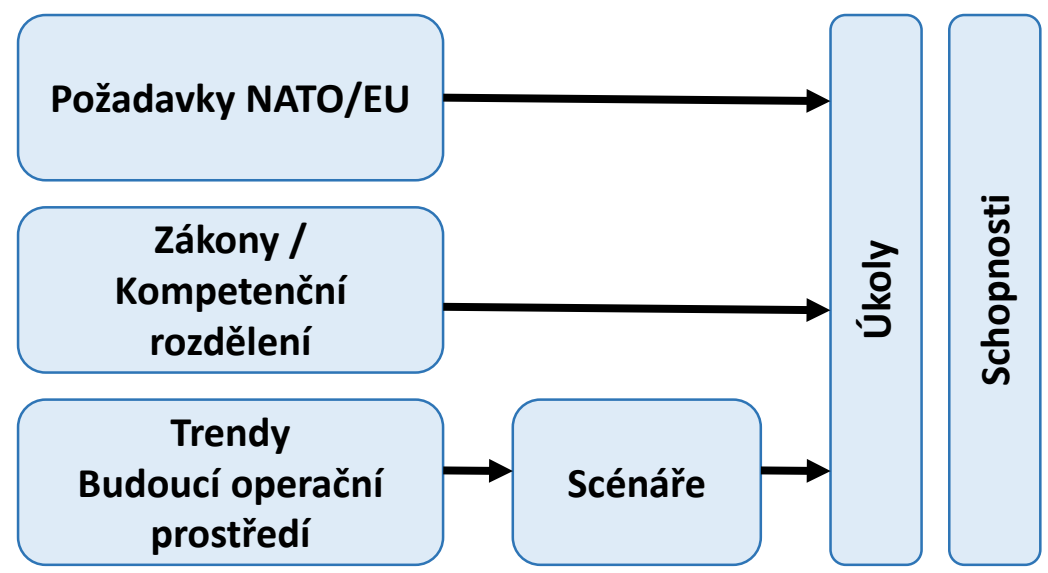

Obrázek č. 1: Zdroje úkolů a schopností

\section{VYMEZENÍ POJMŮ}

Kybernetický prostor (cyberspace, též kyberprostor) vymezuje další pojmy, jako napřiklad kybernetické operace či kybernetická bezpečnost, jeho definice je tedy primární. Zákon o kybernetické bezpečnosti definuje kybernetickým prostorem „digitální prostředí umožňující vznik, zpracování a výměnu informací, tvořené informačními systémy a službami a sítěmi elektronických komunikaci". Kybernetický prostor je zde jasně definován technickým výčtem potřebné infrastruktury a výčtem, co infrastruktura umožňuje. 
Jiné definice nejsou již tak restriktivní. Definice Spojených států zdůrazňují a rozšiřuji definici o globální rozměr a informační okolí. V definici NATO Cooperative Cyber Defence Centre of Excellence (CCDCOE) je to ještě výraznější „....prostředí formované fyzickými a nefyzickými částmi...." Na druhé straně spektra je pak ruské pojetí, kde se vychází z centrality informací a informačního prostoru, kybernetický prostor je jeho částí a zdůrazňuje se lidská aktivita v tomto prostoru. Český výkladový slovník pak přidává „....označení virtuálního světa... operační doména...“.

Kybernetický prostor je tedy tvořen globální fyzickou sítí technologických infrastruktur umožňující vznik, zpracování, ukládání, výměnu informací a lidské aktivity či virtuální život v něm.

Kybernetická doména je pak vojenské označení pro kybernetický prostor. Je to operační prostředí se svébytnými faktory a dostatečně odlišnými zákonitostmi, vyžadující specifický přístup při vedení bojové činnosti, prostředí, kde se plánují a vedou operace. V současné době NATO uznává čtyři tradiční domény mající fyzickou podstatu: země, moře, vzduch a vesmír. Na Summitu ve Varšavě je uznána i člověkem vytvořená kybernetická doména.

Kybernetická doména má zvláštní povahu, je doménou sama o sobě a zároveň propojuje vojenské platformy působící v ostatních doménách a také vytváří virtuální informační prostor. Přiznání kyberprostoru jako válečné domény není komunitou vnímáno jednoznačně.

Termínem bezpečnost rozumíme „bezpečnost jako stav, kdy jsou na nejnižší možnou míru eliminovány hrozby pro objekt (zpravidla národní stát, popř. i mezinárodní organizaci) a jeho zájmy a tento objekt je k eliminaci stávajících i potenciálních hrozeb efektivně vybaven a ochoten při ní spolupracovat".

Kybernetické bezpečnost je stav, kdy jsou na nejnižší míru eliminovány hrozby pro ČR působící z kybernetického prostoru.

Obrana je definována v zákoně o obraně takto:

„Obrana státu je souhrn opatření k zajištění svrchovanosti, územní celistvosti, principů demokracie a právního státu, ochrany života obyvatel a jejich majetku před vnějším napadením. Obrana státu zahrnuje výstavbu účinného systému obrany státu, prípravu a použití odpovídajících sil a prostředků a účast v kolektivním obranném systému."

Obrana je kombinací defenzivních a ofenzivních činností a opatření, at' už aktivního, či pasivního charakteru. Dále je termín obrana používán jen v nejširším významu jako souhrn ofenzivních a defenzivních činností na úrovni státu.

V souvislosti s kybernetickou obranou (obranou v kybernetickém prostoru) se vznášejí nad termínem pochybnosti. Jako protiklady se pak staví obrana zaměřená na odolnost a aktivní obrana. Aktivní obrana je ale z pohledu vojáka nedílnou součástí obrany.

Kybernetická obrana je zde chápána jako obrana v kybernetickém prostoru a skrze (prostřednictvím) něj. 


\section{SOUČASNÝ STAV KYBERNETICKÉ OBRANY A STANOVENÉ ÚKOLY}

Úroveň České republiky. Legislativní zpracování zajištování kybernetické bezpečnosti je v ČR na velmi vysoké úrovni. Platí zákon o kybernetické bezpečnosti, je zpracována strategie směřování a akční plán dosažení cílů. Gestorem za oblast kybernetické bezpečnosti byl Národní bezpečnostní úrad (NBÚ) a jeho součást Národní centrum kybernetické bezpečnosti (NCKB), od 1. 8. 2017 je to Národní úřad pro kybernetickou a informační bezpečnost (NÚKIB). $K$ jeho hlavním úkolům patří provoz vládního CERT (Computer Emergency Response Team) České republiky, a jeho spolupráce s obdobnými organizacemi na národní i mezinárodní úrovni, státními či nestátními. K celkovým činnostem patří i osvěta a podpora vzdělávání, výzkum a vývoj v oblasti kybernetické bezpečnosti a v neposlední řadě také tvorba př́slušných standardů.

NÚKIB vzhledem ke své působnosti dané zákonem číslo 205/2017 Sb. může řešit útoky pouze ochranou a zvyšováním odolnosti vlastních systémů. Zasažení a eliminace útočníka, poprípadě jeho izolace je $v$ této době v poněkud šedé zóně. Budování schopností kybernetické obrany ČR je přiděleno Vojenskému zpravodajství.

Kybernetická obrana je konsensuálně chápána jako součást širšího konceptu kybernetické bezpečnosti, viz obrázek č. 2 .

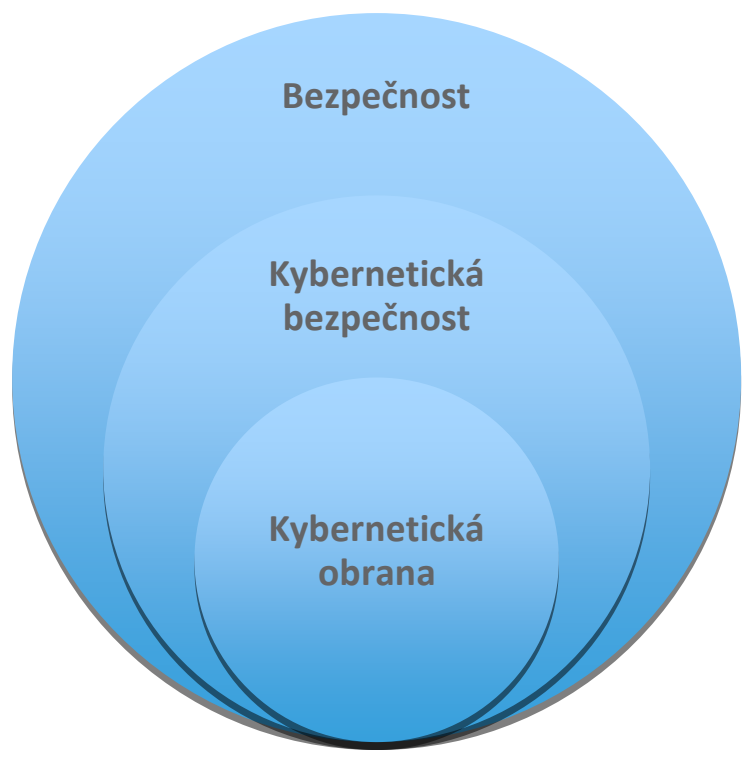

Obrázek č. 2: Vztah bezpečnosti, kybernetické bezpečnosti a kybernetické obrany 
Úroveň Ministerstva obrany: $V$ letech 2005-2009 bylo vybudováno centrum CIRC $\checkmark$ rámci príijetí a plnění závazků vůči NATO v oblasti neutajovaných systémů. Dále byla $\checkmark$ roce 2012 zpracována Koncepce kybernetické obrany rezortu Ministerstva obrany. Rezort zahájil spolupráci s NBÚ a NCKB na legislativních změnách a byla identifikována kritická obranná komunikační infrastruktura rezortu obrany.

Na Ministerstvu obrany je gestorem odpovědným za oblast kybernetické bezpečnosti odbor bezpečnosti $\mathrm{MO}$ (OB MO). Vojenské zpravodajství je odpovědné za oblast kybernetické obrany ČR včetně výstavby sil a prostředků pro zajištění kybernetické obrany ČR. ${ }^{1}$

V průběhu let 2015 a 2016 dochází vlivem prijetí národní strategie kybernetické bezpečnosti ke kvalitativnímu posunu vnímání zajištování kybernetické bezpečnosti. OB MO zpracovává návrh Strategie kybernetické bezpečnosti rezortu Ministerstva obrany na období let 2017 až 2020 (dále rezortní strategie) a souvisejícího akčního plánu. ${ }^{2}$ V průběhu zpracování je jedna z největších překážek nezájem či absence operační komunity.

Strategie rozvijí a upevňuje část zajištování bezpečnosti, odolnosti a bezpečnosti informací. Je zde velmi patrná snaha o rozšíření kybernetických aspektů do vedení operací v souladu s požadavky NATO na Cyber Defence a zajištění bezpečnosti dodavatelského řetězce. Na rezortní úrovni také strategie správně zahrnuje do zajištování kybernetické bezpečnosti jak utajované, tak neutajované systémy. $V$ oblasti spolupráce s průmyslem a zahraniční spolupráce je velmi vyčerpávající.

$\checkmark$ přípravě a výcviku je dle názoru autorů nedostatečně zdůrazněn význam vzdělávání všech př́islušníků rezortu, a to na základní uživatelské úrovni, kde dochází k nejčastějším narušením bezpečnosti. Techniky využívající sociálního inženýrství a lidský faktor všeobecně jsou v kybernetickém prostoru jedním ze slabých míst v bezpečnosti.

Celkově současné uspořádání je $v$ základním konceptu vhodné a pokrývá potřeby rezortu. Systém ale trpí podobnými problémy jako na státní úrovni. Budování schopností obrany a bezpečnosti probíhá do značné míry odděleně a s nejasnostmi při přechodu mezi jednotlivými oblastmi. Je poměrně jasně stanoveno a prodiskutováno dělení v negativním pojetí, tedy co kdo nedělá nebo nesmí dělat, ale jak jednotlivé nástroje rezortu efektivně integrovat pro plnění úkolů je nedořešeno. $V$ současném bezpečnostním prostředí, kde jsou hranice mezi jednotlivými hrozbami velmi nejasné a často i tak záměrně postavené, již není možné pracovat pouze $v$ jednotlivých oblastech bez společného působení. Integrace kybernetických schopností v rámci společného pưsobení disponibilních sil a prostředkủ je nutností.

I na rezortní úrovni je zcela zrejmá tendence redukce bezpečnosti v kybernetickém prostoru pouze na řešení hrozeb technického charakteru. O informačním působení a strategické komunikaci se ani koncepce, ani nová strategie nezmiňují.

1 Usnesení vlády České republiky ze dne 25. května 2015 č. 382: k Akčnímu plánu k Národní strategii kybernetické bezpečnosti České republiky na obdobi let 2015 až 2020. 2015.

2 Akční plán k Národní strategii kybernetické bezpečnosti České republiky na období let 2015 až 2020. Dostupné z: 1url.cz/ht4m2. 
Úroveň Armády České republiky: Na koncepční a doktrinální úrovni má AČR dobre zpracovánu schopnost odolnosti a bezpečnosti informací v rezortních neutajovaných sítích. Založení CIRC předběhlo dobu. Dosažení potřebné úrovně schopností však brání nedostatek kvalifikovaného personálu a financí na jedné straně a neochota vojáků všech stupňů brát kybernetickou obranu vážně na straně druhé. Možnosti a funkce CIRC jsou tak v praxi bohužel omezené a to tak plně nezabezpečuje ochranu rezortních sítí.

V požadovaném stavu v roce 2025 je v KVAČR uvedeno: „Armáda ČR bude mít, v součinnosti s orgány odpovědnými za kybernetickou bezpečnost a obranu, schopnosti plánování a rízení operací v kybernetickém prostoru.....3 Následně jsou uvedeny tři oblasti: (1) kybernetická bezpečnost bude řešena komplexně a vytvoří se struktura řídících a výkonných orgánů, (2) významnou částí je CIRC (s výčtem jaké schopnosti by měl mít) a (3) obranu má na starosti VZ, jak národní, tak podporu operací AČR.

Je zde zřetelná silná redukce zajištování bezpečnosti na schopnost odolnosti a bezpečnosti informací, a to ještě $v$ rámci mírové infrastruktury rezortu. $Z$ textu je zřejmý náhled na zajištování kybernetické bezpečnosti jako technickou odbornou službu, která není integrována a není součástí vedení operací. Další významné schopnosti potřebné pro vedení operací v kybernetické doméně se neřeší.

Rozdíly v chápání pojmu kybernetická obrana. Je nutné zdůraznit skutečnost, že ve vnímání pojmů "Cyber Defence" a „kybernetická obrana“ jsou v prostředí České republiky významné rozdíly. $V$ souvislosti s vymezením působností tak působí proti efektivnímu koordinovanému př́stupu k hrozbám, a potencionálně vytváří duplicity nebo, a to je častější, mezery v celkovém systému.

V zákoně o zajištování obrany je obrana souhrn opatření zahrnující výstavbu, přípravu a použití sil a prostředků „,k zajištění svrchovanosti, územní celistvosti, principů demokracie a právního státu, ochrany života obyvatel a jejich majetku před vnějším napadením“. ${ }^{4}$ Zákon nespecifikuje, jakou povahu má vnější napadení.

Úkoly proto zahrnují reakce na technické a informační napadení, získávání informací, ofenzivní a defenzivní operace a jako základ odolnost vlastních sítí a takto vymezují i obranu v kybernetickém prostoru. Z pohledu obrany tedy zahrnují vše kromě odolnosti nevojenských sítí.

NATO chápe kybernetickou obranu jako ochranu a odolnost vlastních sítí tedy aplikaci bezpečnostních opatření k obraně infrastruktury komunikačních a informačních systémů (KIS) proti kybernetickým útokům. Pojem kybernetická bezpečnost nedefinuje, využívá pojem bezpečnost KIS (CIS Security). Požadavky NATO v oblasti Cyber Defence se ve velké mîre překrývají s požadavky na realizaci opatření kybernetické bezpečnosti ve smyslu zákona o kybernetické bezpečnosti u systémů kritické informační infrastruktury. Pohled NATO na kybernetickou obranu se tedy ve velké míře překrývá s pohledem a vymezením kybernetické bezpečnosti.

Nutno ale zmínit, že pohled NATO se v průběhu času rozšiřuje do zajištění odolnosti systémů (včetně nasaditelných) při vedení operací. $V$ rezortu obrany, a především pak

3 Koncepce výstavby Armády České republiky 2025: upravená verze ke zveřejnění. Praha: Ministerstvo obrany, 2015.

4 Zákon č. 222/1999 Sb., o zajištování obrany České republiky. In: Sbírka zákonů. 1999. 
v ozbrojených silách, nebyl zatím tento rozširrený pohled dostatečně vnímán. Často je kybernetická bezpečnost a kybernetická obrana chápána pouze jako zabezpečení sítí bez vlivu na vedení operací. Tento názor se však v posledních dvou letech začíná měnit.

Pohled NÚKIB (dřive NCKB) je do značné míry vymezen v zákoně o kybernetické bezpečnosti a rozdělením rolí $v$ rámci státní správy. Je zde užší pojetí ve smyslu útoků pouze technického rázu a informační působení nepřítele vůbec neuvažuje. Kritéria, zda se jedná o kybernetickou bezpečnost nebo obranu, jsou následující: (1) povaha hrozby a (2) typ a cíl útoku. ${ }^{5} \mathrm{~V}$ prípadě kybernetické obrany útoky pochází ze zahraničí a jejich motivací jsou politické cíle, na rozdíl od kriminality, kde je primární finanční prospěch. Dále cílem musí být národní aktiva kritická pro fungování státu a intenzita musí překročit schopnost účinné reakce v rámci zákona o kybernetické bezpečnosti. Je tedy možné říci, že pokud útok přichází zvenčí, má jiné než finanční zájmy (kriminalita), útočí na kritickou infrastrukturu a intenzita překročí určitou mez, je možné nebo nutné použít prostředky kybernetické obrany.

Kybernetická obrana ČR je přidělena v rámci rezortu obrany Vojenskému zpravodajství. Vnímání Vojenského zpravodajství je ovlivněno charakterem a zaměřením instituce a zároveň jejím začleněním pod Ministerstvo obrany jako součást obranného systému. Chápání VZ je možné odvodit z návrhu novelizace zákona o Vojenském zpravodajství. V zákoně o zajištování obrany se přidává „Obrana státu, jejíž součástí je také obrana státu v kybernetickém prostoru (dále jen „kybernetická obrana“)“ a také „Kybernetickou obranou se rozumí souhrn opatření [...] podle zákona o Vojenském zpravodajství. V zákoně o Vojenském zpravodajství se navrhuje svěřit VZ „předcházení, zastavení nebo odvrácení kybernetického útoku ohrožujícího zajištování obrany České republiky“ a používat k tomu technické prostředky a související postupy a opatření. VZ svou úlohu vidí jednak v efektivním sběru informací v a prostřednictvím kybernetického prostor a hlavně při obraně kybernetického prostoru ve smyslu aktivního působení na původce útoku. Tedy vlastně vedení kybernetických operací bud' (a to především) ve prospěch obrany ČR, nebo i při podpoře zasazených jednotek ozbrojených sil.

Vyjasnění terminologie je pro studium a vedení odborného diskurzu zásadní. $V$ praxi tyto nejasnosti přinášejí mnohé problémy a rozpory. Zatím se to řeší tak, že pokud se mluví o kybernetické obraně ve smyslu NATO, používá se anglický termín Cyber Defence. Pokud se použije termín kybernetická obrana, máme na mysli odpovídající činnost Vojenského zpravodajství, a pokud mluvíme o odolnosti a zabezpečení vlastních sítí, informačních systémů a infrastruktuře, jde o kybernetickou bezpečnost.

Autoři vycházejí z předpokladu, že budování a použití prostředků obrany v kybernetickém prostoru patři do rezortu obrany, stejně jako ozbrojené síly, které jsou dominantní složkou silového působení v obraně obecně. Zatím Ize obecně vycházet ze zákona o zajištování obrany, jehož zatím blíže nespecifikovanou součástí je i obrana v kyberprostoru.

V současném systému tak chybí přesné vymezení, co je obrana v kybernetickém prostoru, a od toho se odvíjejí problémy způsobené neexistencí systémů řízení a koordinace mezi kybernetickou bezpečností a kybernetickou obranou mimo běžné sdílení informací.

5 PAČKA, Roman. Difference between Cyber Security and Cyber Defence from Czech perspective. Cyber Security Review. 2015, (Spring 2015), 20-24. ISSN 2055-6950. 
Vymezení zodpovědností v různých intenzitách a rozsahu útoků, předávání zodpovědností, tedy kdo rozhoduje a řídí, je v dnešní době nejasné.

Využívání informací jako nástroje moci, a tedy i informačního působení ve své nejširší podobě není v České republice téměř vůbec rozvinuté. ${ }^{6} \mathrm{Na}$ národní úrovni je zahrnutí informačního působení ve strategických dokumentech na minimální úrovni. Informační působení v kyberprostoru není výjimkou. Ve světle hybridních hrozeb začíná rezort obrany podnikat kroky $\mathrm{k}$ nápravě a rozvíjet teorii a praxi strategické komunikace a $\mathrm{v}$ jejím rámci informační operace ${ }^{7}$. Řešení absence informačního působení na úrovni ČR jde za rámec článku, přesto je nezbytné upozornit na mezeru v bezpečnostním systému ohrožující zájmy České republiky.

Severoatlantická aliance: Principy použití ozbrojených sil jsou stanoveny v doktrínách. Přesné požadavky na schopnosti, tedy co, $v$ jaké kvalitě a kvantitě je třeba mít $\mathrm{k}$ dispozici, NATO formuluje $v$ rámci obranného plánování jako cíle schopnosti (CT - Capability Targets).

Je třeba zdůraznit, že konsensuální rozhodovaní Aliance determinuje i stanovené úkoly a požadované schopnosti. $V$ rámci kompromisu se vždy jedná o minimální společně odsouhlasené konkrétní požadavky a náročné vize či směřování, tedy i v případě Cyber Defence.

Z pohledu NATO je kladen v oblasti Cyber Defence důraz na odolnost sítí a bezpečnost informací. Postupem času se stále více prosazuje myšlenka a nutnost integrovat opatření Cyber Defence do př́pravy a operačního použití sil, což se ukazuje právě i na deklaraci kybernetického prostoru jako domény. Na druhou stranu ale nepanuje shoda ohledně ofenzivního působení v kybernetickém prostoru. Budování ofenzivních schopností se tak nechává na rozhodnutí jednotlivých států a zároveň se mlčky předpokládá, že v př́padě potřeby budou tyto schopnosti poskytnuty ve prospěch všech.

Evropská unie: Vývoj v Evropské unii probíhá v podstatě obdobně, i s tradičním rozdělením rolí či pohledů mezi EU a NATO. Strategie EU se více zabývá nevojenskou složkou, ${ }^{8}$ internetem a jeho dopady na každodenní život. Oblast Cyber Defence je v EU vnímána jako dimenze kybernetické bezpečnosti. ${ }^{9}$ Je také považována za opatření k obraně kritických systémů a informací za účelem dosažení kybernetické bezpečnosti. ${ }^{10}$ Mezi NATO a EU je v únoru 2016 podepsáno ujednání o spolupráci (Technical arrangement in Cyber Defence).

Velký důraz je tak kladen na minimalizaci kybernetické kriminality a mezinárodní spolupráci, zavedení a sladění soudržné mezinárodní politiky EU v kybernetickém prosto-

6 ŘEHKA, Karel. Strategická komunikace a informačni operace v resortu MO ČR. Brno, 2016. Závěrečná práce v kurzu Generálního štábu. Univerzita Obrany, Centrum bezpečnostních a vojenskostrategických studií.

7 Ibid, s. 68 „Informační operace jsou vojenská štábní funkce pro koordinaci informačních aktivit s cílem vytvářet požadované účinky na vưli, porozumění a schopnost protivníků, potencionálních protivníků a dalších cílových skupin k podpoře zabezpečení obrany ČR a cílů operací AČR."

8 Ve srovnání s NATO, což je pochopitelné. NATO je obranná aliance, EU má mnohem širší záběr.

9 Většinově chápána jako vojenská dimenze, ale zahrnující jak vojenské, tak civilní přístupy.

10 EUROPEAN UNION CONCEPT FOR EU-LED MILITARY OPERATIONS and MISIONS [online]. Dostupné z: 1url. $\mathrm{cz} / \mathrm{Nt} 4 \mathrm{mG}$. 
ru. Dalším prvkem evropské politiky je zdůraznění spolupráce v rámci Evropské obranné agentury (EDA - European Defence Agency) a s průmyslovým sektorem.

\section{Souhrn úkolů vyplývajících z dokumentů NATO a EU}

Analýzou politik, konceptů a cílů schopností je možné shrnout úkoly do následujících hlavních požadavků:

- zodpovědnost za vlastní sítě,

- odolnost a bezpečnost informací,

- interoperabilita sítí a kybernetické obrany,

- sdílení informací,

- společné vzdělávání,

- spolupráce s průmyslem,

- spolupráce s akademickou sférou,

- začlenění Cyber Defence do plánování a vedení operací,

- začlenění Cyber Defence do vojenských cvičení,

- jasná struktura velení a řizení v kybernetické oblasti,

- schopnost tvorby společného obrazu o stavu vlastních sítí a kybernetického prostoru.

Úkol vyplývající ze zákona o kybernetické bezpečnosti ${ }^{11}$ a souvisejících koncepčních dokumentů:

Úkoly dané právním rádem zahrnují:

- ochranu vlastních neutajovaných sítí a kritické infrastruktury,

- ochranu vlastních utajovaných sítí (zákon výslovně neřeši),

- kybernetickou obranu,

- splňování stanovených standardů pro systémy zařazené do významných informačních systémů a kritické infrastruktury,

- povinnost podávat a sdílet informace,

- provádění opatření k ochraně sítí a infrastruktury,

- systém koordinace,

- systém velení a řízení.

\section{HODNOCENí AKTUÁLNÍHO STAVU A VYMEZENí PROBLÉMU}

V rámci České republiky je $v$ současné době kladen důraz na zajištění kybernetické bezpečnosti. Na velmi vysoké úrovni je právní rámec a rozvojové strategické dokumenty na úrovni ČR i rezortu obrany v oblasti kybernetické bezpečnosti. Gestorem za oblast kybernetické obrany bylo určeno Vojenské zpravodajství. Není však shoda, co vlastně kybernetická obrana vše zahrnuje. Panují nejasnosti v systému řizení a koordinace a vymezení zodpovědností v různých situacích.

$\checkmark$ rámci rezortu a ozbrojených sil jsou schopnosti kybernetické bezpečnosti a kybernetické obrany budovány odděleně. Kybernetická obrana je tak nedostatečně integrována

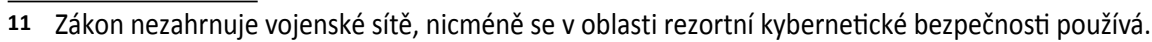


do komplexního vedení obrany a operací ozbrojených sil pod jednotným velením. Oblast obrany v kybernetickém prostoru je silně technicky orientována. Na kyberprostor se nepohlíži jako na součást informačního prostředí. Informační působení a zisk informací na operační úrovni tak není řešen vůbec.

Úkoly vyplývající ze členství v NATO a EU a stanovené právním řádem ČR se vzájemně prolínají a fakticky se soustředí opět spiše na kybernetickou bezpečnost. NATO rozšiřuje svůj pohled a požaduje integraci do vedení operací.

\section{BUDOUCÍ OPERAČNÍ PROSTŘEDí, SCÉNÁŘE A VYPLÝVAJící ÚKOLY}

\subsection{Analýza trendů}

Analýza trendů slouží jako základ pro zpřesnění obrazu budoucího operačního prostředí a tvorbu scénářů. Níže jsou uvedeny jednotlivé faktory vnějšího prostředí relevantní pro kybernetickou obranu dle metody PESTLE.

Politický. $V$ politické oblasti dojde $\mathrm{k}$ výrazným změnám v rovnováze moci a síly aktérů. Budou vznikat nová centra moci a tradiční se budou snažit udržet svůj podíl na mezinárodní scéně. Současné uspořádání mezinárodních vztahů bude pod tlakem vzájemně soupeřících zájmů, komplikované růstem vlivu nestátních a nadnárodních aktérů.

Ekonomický. Svět je a bude ekonomicky propojený a vzájemně závislý. Globalizace umožňuje obrovský pohyb zboží, kapitálu, práce a služeb a s tím navázaný růst. Stinnou stránkou je náchylnost k rychlému šiření krizí bez možnosti kontroly a vlivu většiny států, a nerovnoměrně rozvržené zisky z globalizace. Nárůst požadavků na zdroje rozvíjejících se zemí ve spojení s růstem populace povede ke zvýšení soutěže o zdroje.

Sociální. Lidská populace bude nerovnoměrně růst a přesunovat se do měst. Nerovnoměrné rozdělení bohatství, možností pro lidský rozvoj a přeplněností obyvatelstva $v$ některých částech světa povede $k$ migračním tlakům a s tím souvisejícími problémy integrace $v$ jiných zemích. Technologické a kulturní změny urychlí rozpad tradičních hodnot a povedou ke krizím identity.

Technologický. Rozvoj technologií zrychluje změny ve světě a umožnuje propojení světa do jedné globální informační vesnice. Rozšíření a dostupnost technologií umožnilo využít vyspělých technologií i nestátním aktérům a jednotlivcům. Umělá inteligence, robotické systémy a jejich prolnutí do společnosti mění zavedené způsoby života. Některé vědecké a technologické objevy mohou mít až disruptivní potenciál a kontrola jejich dopadů bude obtižná. 
Právní. Uspořádaní mezinárodních vztahů a právního sytému se bude kontinuálně vyvíjet. Všichni aktéři, tedy i nestátní, se budou snažit měnit a využívat současné normy a pravidla ve svůj prospěch. Právo se stane běžným nástrojem pro vedení konfliktů a formou zbraně. Roste význam individualit a uspokojení jejich potřeb. Lidská práva a jejich rozšiřování se stávají předmětem sporu.

Environmentální. Trendy v oblasti životního prostředí nejsou prímo relevantní.

Budoucí operační prostředí: Svět se rychle mění a s ním se mění i operační prostředí a charakter soudobých konfliktů. Válka se již nevyhlašuje, ubývá konfliktů mezi státními aktéry, klasický konvenční konflikt je už výjimkou. Naopak narůstá zapojení nestátních aktérů a jejich vliv na charakter konfliktů. ${ }^{12}$

Největší změny $v$ mezinárodním uspořádání a mezinárodním právním systému je možné očekávat v oblastech, které jsou v současné době definovány nejasně, minimálně nebo vůbec. Jednotliví aktéři budou chtít prosadit své zájmy v rámci právě vytvářeného systému a stvořit normy a pravidla vyhovující jejich parciálním zájmům. Týká se především využívání globálních veřejných statků, specificky využívání přírodních zdrojů v mezinárodních vodách nebo využívání vesmíru, a především kybernetického prostoru.

Globalizovaný a propojený svět umožňuje rychlé přelévání konfliktů a jejich dopadů i do vzdálených oblasti. ${ }^{13}$ Zároveň rozpad unipolárního světa vytvořil prostor k realizaci ambicí i lokálních aktérů, z čehož pak vyplývá rostoucí komplexita, provázanost a obtí̌ná předvídatelnost bezpečnostního prostředí.

Roste podíl asymetrických, nekonvenčních složek konfliktů. ${ }^{14}$ Různorodost aktérů současných konfliktů vede k široké škále používaných strategií a metod řešení konfliktů.

Na vzestupu jsou hybridní a komplexní strategie. ${ }^{15}$ Stírají se rozdíly mezi vnitřní a vnější bezpečností. Hrozby jsou rozmanité a propojené. Využívá se nejasné hranice mezi mírovým soutěžením a agresí. Bez komplexního přístupu $\mathrm{k}$ řešení hrozeb již není možné efektivně reagovat.

Jedním z dominantních trendů poslední doby determinovaných technologickým rozvojem, je pak nástup centrality informací a kybernetického prostoru jako místa konfliktu. Svět charakterizuje „bezprecedentní a stále rostoucí informační propojenost světa v důsledku globalizace, a především díky dostupnosti internetu a informačních technologiii“" ${ }^{16}$ Veřejná i soukromá sféra je závislá na informačních a komunikačních technologiích. S tím roste i riziko a závažnost dopadů na (kritickou) informační infrastrukturu.

Svět je poměrně snadné narušit útokem na „nervový systém“, tedy propojenost vytvářenou v kybernetickém prostoru. Dalším vektorem útoku je rozvrácení morálky obyvatelstva $v$ postmoderním světě, kdy člověk, který ztrácí morální a lidskou orientaci 
podléhá manipulativnímu působení propagandy. Vztah mezi člověkem a kybernetickým prostorem vytváŕí mnohé výzvy a př́ležitosti pro vojenské využiti. ${ }^{17}$

\subsection{Scénáře relevantní pro kybernetickou obranu}

Byly zpracovány čtyři základní scénáře, přičemž dva jsou dominantně strategické úrovně s přesahem do operační úrovně. První je zaměřený na masivní technický kybernetický útok na zájmy státu a druhý je zaměřený na informační působení v kybernetickém prostoru. Další dva scénáře se zaměřují na roli kybernetické domény při vedení operací. První rozvíjí činnosti a úkoly při vedení společných (JOINT) operací a druhý při řešení národních úkolů při únosu českých občanů v zahraničí.

Zpracování scénářů umožní podrobněji rozpracovat možné úkoly, které bude nutné $v$ rámci scénáře plnit. Vyplývající úkoly následně napomohou $\mathrm{k}$ přesněǰ̌ímu stanovení požadavků na schopnosti. Scénáře jsou dále doplňovány o podrobnosti z dalších relevantních zdrojů, tedy scénářů vytvořených pro potřeby NATO, či přímo ČR. Ze scénářů jsou použity části vztahující se ke kybernetickému prostoru nebo pro nutný kontext a okolí.

Struktura scénářů je následující:

- důvody pro scénár,

- přiběh popisující možnou situaci a její vývoj,

- situace ve struktuře PMESII (kontext),

- cílový stav relevantní pro scénár, ${ }^{18}$

- úkoly, které bude nutné plnit.

Scénáře nejsou uvedeny v plném rozsahu. Pro účely článku je zestručněn příběh, vynechán kontext a shrnutí úkolů. Cíle a úkoly v rámci scénářů nemusejí být vždy v souladu se současnou právní úpravou nebo kompetenčním rozdělením působností. Scénáře představují výchozí návrh, jak odvodit požadované schopnosti kybernetické obrany a netvoří úplnou sadu pokrývající všechny možné situace.

\section{Technologické napadení}

Scénář kybernetického útoku technologického charakteru je jednou z deseti tzv. „,nestabilních situaci“ vyjádřených v FFAO. ${ }^{19}$ Útok na kritickou infrastrukturu ${ }^{20} v$ kybernetickém prostoru a prostřednictvím kybernetického prostoru má „závažný dopad na bezpečnost ČR, zabezpečení základních životních potřeb obyvatelstva nebo ekonomickou situaci". ${ }^{21}$

17 DUGGAN, Patrick. Why Special Operations Forces in US Cyber-Warfare? Cyber Defense Review [online]. 2016(2) [cit. 2017-06-20]. Dostupné z: http://1url.cz/st4mz.

18 Strategické, politické, vojenské, operační dle relevance v rámci scénáře.

19 Framework for Future Alliance Operations. Norfolk, Virginia: North Atlantic Treaty Organisation, Supreme Allied Command Transformation, 2015.

20 Jedná se o infrastrukturu kritickou pro fungování státu, nejen o kritickou informační infrastruktur dle zákona č. 181/2014 Sb.

21 Audit národní bezpečnosti. Praha: Ministerstvo vnitra České republiky, 2016. Dostupné z: 1url.cz/etEas, s. 95. 


\section{Příběh:}

Webové stránky státních úřadů včetně Úřadu vlády a Ministerstva obrany jsou nedostupné z důvodu DDoS útoku. ${ }^{22}$ Nedostupnost služeb hlásí některé banky a systém elektronické evidence tržeb. Ředitel NÚKIB vyhlašuje stav kybernetického nebezpečí a rozhoduje o provedení reaktivních opatření.

NÚKIB ve spolupráci s Ministerstvem vnitra a zpravodajskými službami intenzivně hledá zdroje nepřátelského působení. O pomoc jsou požádány mezinárodní instituce.

Intenzita nepřátelských útoků se stupňuje, je napadena elektrická rozvodná sít, a dochází k masivním výpadkům dodávky elektřiny ve velkých městech.

Zdroj nepraátelského působení je lokalizován do prostoru Ruska a států jižní části bývalého Sovětského svazu. Bezpečnostní rada státu a poté vláda, jednomysIně považuje kybernetický útok za ozbrojené napadení České republiky a vyhlašuje stav (kybernetické) nouze. Dále žádá NATO o aplikaci článku 5. NATO v rámci dohod vysílá svůj Rapid Reaction Team do ČR.

ČR aktivuje své obranné schopnosti. V součinnosti všech relevantních složek se částečně daří odrážet kybernetické útoky a vracet některé služby do alespoň omezeného provozu. Nepřátelské působení nepolevuje, je nutné eliminovat zdroj. Na mezinárodním poli vrcholí diplomatická a právní bitva, Rusko odmítá zodpovědnost za útoky či původ působení ze svého teritoria. Je rozhodnuto o provedení cílených kybernetických útoků na aktivní zdroje.

Koordinovaným působením všech složek včetně pomoci od NATO a některých spojenců je kybernetický útok zastaven, zasažená kybernetická infrastruktura je postupně zprovozňována a kybernetický prostor se vrací k normálu.

Cílový stav:

- služby obyvatelstvu jsou obnoveny,

- kritická infrastruktura státu je v provozu,

- důvěra ve schopnost vlády ochránit kritickou infrastrukturu před útoky z kyberprostoru je udržena.

\section{Informační napadení}

Scénář informačního útoku či spíše informačního působení ${ }^{\mathbf{3}}$ v kybernetickém prostoru je v poslední době stále aktuálnější. V Auditu národní bezpečnosti²4 se informační působení objevuje především v částech kybernetické hrozby, pưsobení cizí moci a hybridní hrozby. Systematické informační působení v kybernetickém prostoru ČR at' státního či nestátního aktéra již nyní probíhá. ${ }^{25}$ Ovlivňování veřejného mínění cestou nepřátelského informačního působení je hrozbou pro životní a strategické zájmy ČR.

22 DDoS útok (distributed denial-of-service attack) - útok na internetovou službu či webovou stránku zahlcením požadavky, jehož cílem je nedostupnost pro normální uživatele.

23 Působení lépe zdůrazňuje dlouhodobost a charakter hrozby.

24 Audit národní bezpečnosti. Praha: Ministerstvo vnitra České republiky, 2016.

25 Ibid, s 99-100. 


\section{Příběh:}

Zpravodajské služby zvyšují své schopnosti pro získávání informací z kybernetického prostoru at' z otevřených či zakrytých zdrojů. V nepřátelské kybernetické špionáži zvyšují aktivitu Rusko a Čína. Důvěryhodnost zpravodajských serverů a tradičních médií klesá, obyvatelstvo se obrací spíše k alternativním zdrojům informací na internetu a sociálním sítím. Komunikační prostor se fragmentuje, což ovlivňuje i domácí politiku. ${ }^{26}$

Dochází ke krizi identity, což využívá Rusko k intenzivnímu informačnímu působení27. Cílem je upevnit a prohloubit antisystémové postoje ${ }^{28}$ Schopnost lidí spolehlivě rozlišovat se snižuje vlivem zdokonalených dezinformačních metod. To vše snižuje důvěru v politické instituce a tradiční zdroje autority. Kybernetický prostor umožnuje i šíření idejí násilných extrémistických skupin. Širíi se nenávist, skupiny jako ISIL zde rekrutují bojovníky a získávají své podporovatele. Společnost se stále více polarizuje.

Rusko se snaží ovlivnit rozhodování vlád euroatlantického prostoru a zpochybnit důvěryhodnost a legitimitu vládnutí. Selektivně vybrané a kontextu zbavené informace získané kybernetickou špionáží cíleně uveřejňuje. Tlačí na rozpad západních demokratických struktur a především vnitřní jednoty NATO.

Demokratické státy se snaží reagovat na nepřátelské informační působení, posilují obranyschopnost a vnitřní soudržnost. Intenzivně pracují na skloubení svobody vyjadřování a zajištění bezpečnosti.

Cílový stav:

- jsou minimalizovány negativní dopady informačního působení,

- je zvýšena odolnost společnosti proti nepřátelskému informačnímu působení,

- svoboda a ochrana práv jednotlivce v rámci kybernetického prostoru je nedotčena.

\section{Vedení společných operací v rámci Aliance}

Scénář vedení společných operací je pro praktické použití u ozbrojených sil nejdůležitější. Použití ozbrojených sil v rámci alianční obrany je základním způsobem jejich nasazení, a jejich mírová struktura je takto koncipována. ${ }^{29} \mathrm{~V}$ rámci scénáře není řešeno, jaký bude příspěvek ČR do konkrétní operace, ale spíše co bude potřebovat aliance jako celek. Popis scénáře se soustředí na aspekty dotýkající se kybernetického prostoru a působení v něm, to ale neznamená, že se neplní i jiné úkoly.

\section{Příběh:}

Bezpečnostní situace $v$ baltských státech se zhoršuje. Ruské etnické menšiny se dožadují větší samostatnosti a podílu na moci, vznikají nepokoje. Intenzita kybernetických útoků na infrastrukturu se zvyšuje, dochází k výpadkům sítě. Baltské státy žádají konzultace dle čl. 4. a žádají o posílení jejich bezpečnosti, situace je nejasná.

26 DITRYCH, Ondřej. et al. Scénáře vývoje mezinárodního bezpečnostního prostředí (2016). Praha: Ústav mezinárodních vztahů, 2016, s. 5.

Ibid, s. 31

28 Ibid, s. 5

29 Audit národní bezpečnosti. Praha: Ministerstvo vnitra České republiky, 2016, s. 134. 
Do Pobaltí se přesouvají síly rychlé reakce NATO jako důkaz jednoty a odhodlání ke společné obraně. Manévr je narušován častými problémy ve spojení v důsledku napadání sítí velení a řízení NATO. ${ }^{30}$ Rusko vydává prohlášení o ochraně svých etnických menšin v zahraničí a svém odhodlání je $v$ případě potřeby podpořit. $V$ Baltském moři dochází k incidentu, kdy je lod' vybavená systémem AEGIS ohrožována ruskými letouny a snahou vyřadit naváděcí systémy prostředky elektronického boje. Dochází k odpalu raket a ruský letoun je sestřelen. Není jasné, proč došlo k odpalu raket.

Po sociálních sítích se v oblastech s převahou ruské národnosti šírí informace o násilnostech vojsk NATO. Pokročilé analytické systémy využívající prvky umělé inteligence $v$ téměř reálném čase vytváří výraznou polarizaci nálad ve společnosti a ochotu $k$ násilnému řešení. Ve městech vzniká panika, lidé se připravují na válku, dochází k rabování.

Rusko provádí prověrku pohotovosti svých vojsk v oblasti Kaliningradu a Petrohradu, v pohotovosti je 50 tisíc vojáků. Na operačním velitelství NATO se slad'ují obranné plány ve všech doménách založené na společném pưsobení všech sil a prostředků. Připravuje se manévr a systém paleb především na systémy velení a řízení. V kybernetickém prostoru dochází k intenzivnímu sběru a analýze aktuálních informací o zranitelnostech. Připravuje se série společných útoků vzdušných, námořních a kybernetických sil na místa velení a řízení.

Cílový stav:

- je zajištěna bezpečnost států NATO,

- nepř́tel je odstrašen,

- systémy velení a řízení jsou nenarušeny.

\section{Ochrana národních zájmů}

Scénář použití ozbrojených sil ČR pro ochranu národních zájmů vychází z jednoho z typových plánů. ČR tedy předpokládá v určitých případech chránit své zájmy i za použití sil pod národním velením. Únosy občanů různých států, at́ už z jakéhokoli důvodu poměrně často a výrazně zasahují do domácí politiky. ČR není hlavní cílovou zemí, ale přesto je nutné, aby ozbrojené síly na takovéto situace byly připraveny a poskytovaly vládě možnosti řešení situace. ${ }^{31}$

\section{Příběh:}

Při probíhajícím konfliktu na Předním východě jsou uneseni dva pracovníci humanitární organizace české národnosti. Zároveň jsou napadeny webové stránky humanitárních organizací ukazující, co se stane každému, kdo přijede pomáhat. Únosci se ozvou se svými politickými požadavky. V konfliktu jsou v rámci koalice nasazeny i jednotky AČR.

V průběhu vyjednávání se podaří Vojenskému zpravodajství lokalizovat polohu vyjednavačů do objektu v okrajové průmyslové části města. S pomocí taktických odposlechů, autonomních průzkumných systémů, sledování sociálních sítí a komunikátorů jsou získána potřebná data. Jejich zpracováním s využitím prvků umělé inteligence je potvrzena

30 MAZANEC, Brian M a Bradley A. THAYER. Deterring cyber warfare: bolstering strategic stability in cyberspace. ISBN 978-1-137-47617-3, s. 20

31

Článek neřeší právní aspekt. 
i přítomnost rukojmí. Je rozhodnuto o provedení záchranné operace. Úkolové uskupení speciálních sil je posíleno o jednotku kybernetických operací a modul ISTAR.

Začala spolupráce s lokálními důvěryhodnými prvky, pro což je vytvořena ad-hoc zabezpečená komunikační a informační sít. Místní spolupracovník pronikl do objektu a infikoval systém zabezpečení objektu speciálně připraveným malware.

Odřad je při postupu k objektu chráněn napadením městského sledovacího systému kybernetickým útokem vedeným z ČR. Na sociálních sítích začíná diskuse nad pohybem činností koaličních sil v jiné části města, nepř́tel je klamán a pozornost je odvedena od cíle operace. Při napadení objektu je vypnuto zabezpečení, a tak dosaženo momentu překvapení, rukojmí jsou téměř bez boje osvobozeni a odřad pokračuje na místo vyzvednutí. Systém sledování známých př́slušníků teroristické skupiny ukazuje srocení na směru odchodu. Komunikace mezi základnou a odřadem je rušena a vede se boj o udržení spojení. Konvoj je odkloněn a bezpečně předá osvobozené občany.

Okamžitě začíná kampaň proti unášení civilistů a neschopnosti teroristů. V ČR vláda vydává prohlášení o záchraně humanitárních pracovníků a ujištuje české občany o svém odhodlání a schopnostech zajistit jejich bezpečnost.

Cílový stav:

- rukojmí jsou osvobozena,

- je zachována důvěra ve schopnost ČR chránit své občany.

\section{3 Úkoly vyplývající ze scénářů a jejich uspořádání}

Analýzou možných úkolů vyplývajících ze scénářů je možné pro lepší přehlednost a pochopení úkoly shrnout do několika velkých skupin.

1. Odolnost a bezpečnost informací.

2. Zabezpečování informací v kyberprostoru.

3. Kybernetické operace.

4. Informační působení v kyberprostoru.

5. Koordinační a řídící.

Rozložení a uspořádání v rámci scénářů je možné vidět na obrázku č. 3. Dále budou rozpracovány jednotlivé skupiny úkolů podrobněji.

\section{Odolnost a bezpečnost informací (Information Assurance)}

Skupina úkolů zahrnující dva koncepty, odolnost a bezpečnost informací, ale s výrazným přesahem mezi sebou navzájem. Odolnost (Resilience) je „schopnost organizace, systému či sítě odolat hrozbám a čelit výpadkům. " ${ }^{32} Z$ vojenského pohledu je nutno dodat, že se jedná o aktivity na vlastních systémech. Z nevojenského pohledu je zasahování do jiných, než vlastních systémů nezákonné, a proto se ani neuvažuje.

32 JIRÁSEK, Petr, Luděk NOVÁK a Josef POŽÁR. Výkladový slovník kybernetické bezpečnosti: Cyber security glossary. Třetí aktualizované vydání. Praha: Policejní akademie ČR v Praze, 2015. ISBN 978-80-7251-436-6., s. 78. 


\begin{tabular}{|c|c|c|c|}
\hline Technologické napadení & Informační napadení & Společná operace & Národní operace \\
\hline \multicolumn{4}{|c|}{ Koordinační a řídící } \\
\hline \multicolumn{4}{|c|}{$\begin{array}{c}\text { Zabezpečování informací (zpravodajské zabezpečení) } \\
\text { v kybernetickém prostoru }\end{array}$} \\
\hline \multicolumn{4}{|c|}{ InfoOps v kyberprostoru } \\
\hline \multirow[t]{2}{*}{ Kybernetické operace } & Informační působení & \multicolumn{2}{|c|}{ Kybernetické operace } \\
\hline & & \multicolumn{2}{|c|}{ Nasaditelná odolnost a informační bezpečnost } \\
\hline \multicolumn{4}{|c|}{ Odolnost a informační bezpečnost vojenské infrastruktury } \\
\hline \multicolumn{4}{|c|}{ Odolnost a informační bezpečnost kritické infrastruktury } \\
\hline
\end{tabular}

Obrázek č. 3: Úkoly vyplývající ze scénářů a jejich uspořádání

Bezpečnost informací je pak spíš pohled státních orgánů. V zákoně o kybernetické bezpečnosti je definována jako „zajištění bezpečnosti důvěrnosti, integrity a dostupnosti informací". Odolnost a bezpečnost informací jsou tak úkoly spojené s budováním, bezpečností a ochranou infrastruktury a informací vlastních systémů. ${ }^{33} Z$ vojenského pohledu je ještě nutné rozčlenit tuto oblast na kritickou infrastrukturu, vojenskou kritickou infrastrukturu a nasaditelnou infrastrukturu ${ }^{34}$.

\section{Zabezpečování informací v kyberprostoru}

Zpravodajské služby ${ }^{35}$ mají za úkol „získávání, shromažd’ování a vyhodnocování informací ... důležitých pro ochranu ústavního zřizení, významných ekonomických zájmů, bezpečnost a obranu České republiky“36. Informace zabezpečují i z kybernetického prostoru. V podstatě se jedná bud' o získávání informací z otevřených zdrojů, nebo o kybernetickou špionáž. Na strategické úrovni se informace přímo vztahují k životním zájmům. Další jsou pak informace nutné pro vlastní činnost nebo vedení operací, tedy operační a taktické informace. Informace je možné zjišt'ovat cestou (skrz) kybernetického prostoru o skutečnostech mimo kybernetický prostor nebo o situaci a aktivitách v kybernetickém prostoru. Ve vojenské terminologii pak jde o strategické, operační a taktické zpravodajské zabezpečení. Úkoly v této skupině jsou úkoly plněny dedikovanými orgány, nejedná se tedy o každodenní získávání informací pro vlastní činnost.

33 Pro další pochopení dělení je nutné ještě jednou zdůraznit - aktivity na vlastních systémech. 


\section{Kybernetické operace}

Skupina úkolů tvořící vlastní jádro úkolů působení v kyberprostoru z pohledu obrany. Souhrn opatření, přípravu a použití kybernetických prostředků ofenzivním nebo defenzivním způsobem, aktivního nebo pasivního charakteru.

\section{Koordinace a řízení}

Budoucí operační prostředí, i jeho vyjádření v předcházejících scénářích jasně ukazuje na stírání hranic mezi vnější a vnitřní hrozbou, neurčitostí, zda je nepřátelská aktivita vojenského typu, či kybernetická kriminalita. Není možné se tak na hrozby připravovat a čelit jim v jakýchsi oddělených bublinách, dle organizačních struktur. Bez vzájemné součinnosti, nebo hůře s rivalitou. Úkoly zahrnují koordinaci a vzájemnou synergii všech typů úkolů, vytváření struktur řízení a koordinace, $s$ jasnou zodpovědností a pravomocemi zvláště pak při změnách krizových stavů od nebezpečí až po válečný stav. $V$ čistě vojenské části pak zahrnují začlenění kybernetické domény do plánování a řízení operací, v rámci společného působení všech sil a prostředků k získání převahy nad nepřitelem.

\section{Informační působení v kyberprostoru}

Informační působení je zde nejširší pojem zahrnující veškeré aktivity v kyberprostoru. Z pohledu státu pak především vytváření informačně odolné společnosti, strategická komunikace a v jejím rámci pak při vedení operací ozbrojených sil informační operace.

\section{ZÁVĔR}

Analýza trendů za pomoci faktorové analýzy PESTLE slouží jako podklad pro aplikaci vojenského pohledu a zpřesnění charakteristik budoucího operačního prostředí.

Budoucnost je plná komplexity ${ }^{37}$, rizik, nejistot, hrozeb a príležitostí. Rychlé změny v sociální, vědecké, technologické a environmentální oblasti, jejichž vliv je zvyšován všudypř́tomným efektem globalizace, vytvářejí svět plný neznámých a nepředvídatelnosti. Globalizovaný a propojený svět umožňuje rychlé přelévání konfliktů a jejich dopadů i do vzdálených oblastí. ${ }^{38}$ Zároveň rozpad bipolárního světa vytvořil prostor k realizaci ambicí i lokálních a nestátních aktérů. Roste význam a centralita informací a kybernetického prostoru a zároveň roste závislost společnosti na bezproblémovém fungování kyberprostoru.

Zpracované scénáře umožňují prozkoumat a rozpracovat možné úkoly, které bude nutné plnit při obraně kybernetického prostoru. Scénáře pokrývají situace od masivního kybernetického útoku v době míru, přes informační působení až po vedení bojových operací ve všech doménách, a tedy i kybernetické.

37 Framework for Future Alliance Operations. Norfolk, Virginia: North Atlantic Treaty Organisation, Supreme Allied Command Transformation, 2015.FFAO, s.5

38 Dlouhodobý výhled pro obranu 2030. Praha: Ministerstvo obrany, 2015, s. 3-4. 
Analýza úkolů vyplývajících ze scénářů napomohla určit následující základní skupiny úkolů: (1) odolnost a bezpečnost informací ve vlastních sítích, zajištujících infrastrukturu a informace v ní uložené. Úkoly (2) koordinační a řídící umožní propojit vše dohromady. (3) Zabezpečování informací v kyberprostoru přispěje svým dílem do všezdrojového zpravodajství. (4) Kybernetické operace a (5) informační působení pak přináší aktivní prvek do působení a obrany v kybernetickém prostoru. Na analýzu úkolů navazuje určení požadovaných schopností rezortu obrany a návrh rozdělení rolí, odpovědností a požadovaných schopností, což však přesahuje záměr tohoto článku.

Autoři: $\quad$ RNDr. Dalibor Procházka, CSc., (pplk. v z.). Narozen v roce 1962. $V$ roce 1986 ukončil Fakultu numerické matematiky a kybernetiky Moskevské státní univerzity. $V$ letech 1987-1995 působil jako odborný asistent na katedře Technické kybernetiky a vojenské robotiky Vojenské akademie v Brně, v letech 1995-1997 se zabýval školící a projektovou činností na informačním systému logistiky. Od r. 1998 do roku 2005 se podilel na výzkumu a zavádění prostředků modelování a simulace pro potřeby výcviku a vzdělávání do AČR, v letech 2000-2005 jako velitel Centra simulačních a trenažérových technologií, v letech 2006-2009 jako projektový manažer ve společnosti VR Group, a.s. V letech 2011-2013 se v rámci Sekce obranné politiky a strategie Ministerstva obrany věnoval oblasti informačních systémů, zejména kybernetické obraně. Od června 2013 pracuje jako odborný asistent Centra bezpečnostních a vojenskostrategických studií UO. Zabývá se problematikou modelování a simulace a kybernetické obrany.

plk. gšt. Ing. Miroslav Feix, M.S., narozen 1974. Je absolventem VVŠ PV ve Vyškově a Naval Postgraduate School v Monterey, CA, USA. Působil na různých velitelských a štábních funkcích u Speciálních sil. V současné době pracuje na Ředitelství speciálních sil v oblasti koncepcí a strategií. V současnosti pracuje ve funkci zástupce ředitele speciálních sil Armády České republiky.

Jak citovat: FEIX, Miroslav and Dalibor PROCHÁZKA. Aktuální úkoly kybernetické obrany rezortu Ministerstva obrany. Vojenské rozhledy 2017, 26 (3), 31-50. DOI: 10.3849/2336-2995.26.2017.03.031-050. ISSN 1210-3292 (print), 23362995 (on-line). Available at: www.vojenskerozhledy.cz 


\section{Výsledky výzkumu k problematice ženijní podpory pohybu $v$ bojových operacích}

\section{Results of Research to the Issue of Engineer Support in Combat Operations}

\section{Ota Rolenec, Jan Kyjovský, Jaroslav Zelený, Tibor Palasiewicz}

Abstrakt: Př́spěvek se zabývá schopnostmi ženijních jednotek k poskytování ženijní podpory pohybu v bojových operacích. Na základě analýzy výsledků strukturovaných rozhovorů provedených $s$ rozsáhlým souborem důstojníků Armády České republiky a jejich zobecnění byly zjištěny rozpory mezi současným a požadovaným stavem $v$ organizační struktuře ženijních jednotek k poskytování efektivní podpory pohybu a byly formulovány požadavky na ženijní prostředky k podpoře pohybu v podmínkách Armády České republiky. Cílem tohoto článku je předložit doporučení k zařazení různých typů ženijní techniky do vytvářených ženijních uskupení k podpoře pohybu ve vztahu k plněným úkolům v rámci ženijní role podpory pohybu a stanovit doporučení k dalšímu směřování výzkumu v této oblasti.

Abstract: The paper deals with the ability of engineer units to provide engineer mobility support in combat operations. Based on the analysis of the results of structured interviews conducted with extensive amount of the Czech Armed Forces officers, and their generalization, were found discrepancies between the current and required state in the organizational structure of engineer units to provide effective mobility support, and requirements for engineer devices to support mobility in the Czech Armed Forces conditions were formulated. The aim of this article is to present recommendations for inclusion of different types of engineer devices into formed engineer formations for mobility support in relation to the tasks performed within engineer role of mobility support and determine recommendations for the further direction of research in this area.

Klíčová slova: Bojová podpora; ženijní podpora pohybu; ženijní prostředky; strukturovaný rozhovor.

Key words: Combat Support; Engineer Mobility Support; Military Engineering Devices; Structured Interview. 


\section{ÚVOD}

Podle doktríny AJP-3.2 Allied Joint Doctrine for Land Operations jsou základem všech pozemních operací manévrový přístup a velení v operaci. Manévrový přístup je charakterizován jako získání, udržení a využití iniciativy. V boji manévrový prístup stále obsahuje prvky pohybu, palebné síly a poziční obrany. ${ }^{1}$

Ženijní podpora pohybu je jednou z rolí ženijní podpory činnosti vojsk. Obsahuje úkoly podporující přesuny a manévry vojsk a volnost pohybu v operacích. Jednotlivé úkoly jsou určené jak pro bojové operace, tak pro operace ke zvládání krizí. Armáda České republiky (AČR) se ve své novodobé historii zaměřovala zejména na přípravu a vysílání vojáků do stabilizačních operací a operací na podporu míru. Hlavními procvičovanými tématy u útvarů AČR se tak staly patrolování, techniky na zvládání davu, reakce na improvizované výbušné zařízení apod. Přibližně od roku 2012 se jednotky AČR navrací v obsahu přípravy ke svému základnímu úkolu stanovenému v zákoně č. 219/1999 Sb., o ozbrojených silách České republiky² ${ }^{2}$ což je příprava k obraně ČR a její obrana proti vnějšímu napadení. Ve větší míře se tedy procvičují základní taktické činnosti - obrana a útok. Správnost tohoto rozhodnutí dokazuje současný vývoj mezinárodně-politické situace. ${ }^{3}$

V současné době se nacházejí ženijní prostředky $k$ podpoře pohybu v bojových operacích u útvarů AČR na nevyhovující úrovni, která je důsledkem dynamických změn v jejich organizačních strukturách od počátku 90. let minulého století a rušení různých druhů techniky bez náhrady, popřípadě jejich zastarávání. Podrobnější analýza tohoto stavu je uvedena v článku autora „Použití ženijních jednotek v soudobých operacích při podpoře pohybu brigádního úkolového uskupení. ${ }^{4} \mathrm{~K}$ efektivnímu poskytování podpory pohybu v boji je nutné znát soudobé požadavky příslušníků manévrujících jednotek na ženijní prostředky $\mathrm{k}$ podpoře pohybu a požadovaný způsob poskytování této role ženijní podpory. Obdržené informace a vyvozené závěry mohou představovat významný podnět a vodítko $k$ dalšímu směřování rozvoje ženijního vojska AČR v oblasti ženijní podpory pohybu vojsk v bojových operacích.

\section{POUŽITÉ METODY}

Článek zevšeobecňuje názory respondentů v rámci strukturovaných rozhovorů konaných v období od záŕí 2015 do dubna 2017 s příslušníky Generálního štábu AČR, ve-

1 AJP-3.2. Allied Joint Doctrine for Land operations. Brusel: NSO, 2016.

2 Zákon č. 219 ze dne 12. ř́jna 1999 o ozbrojených silách České republiky. In Sbírka zákonů České republiky. 1999, částka 76. ISSN 1211-1244.

3 Obranná strategie České republiky: The defence strategy of the Czech Republic. Praha: Ministerstvo obrany České republiky - VHÚ Praha, 2017. ISBN 978-80-7278-702-9.

4 ROLENEC, Ota. Použití ženijních jednotek v soudobých operacích při podpoře pohybu brigádního úkolového uskupení. Economics and Management, 2016, č. Mimořádné, s. 80-88. ISSN 1802-3975. 
litelství pozemních sil, 15. ženijního pluku (15. žp), 4. brigády rychlého nasazení (4. brn) a 7. mechanizované brigády (7. mb). Cílem těchto rozhovorů bylo získání poznatků a zkušeností z oblasti podpory pohybu manévrujících jednotek v operacích a dále získání názorů a podnětů na zlepšení současného stavu v dané oblasti. Rozhovor byl proveden celkem s 32 důstojníky, což představuje významný vzorek k získání potřebných a objektivních dat od respondentů v průřezu od nižšího po vyšší management v AČR. Při výběru osob vhodných k provedení strukturovaného rozhovoru byla stanovena následující kritéria:

- důstojník na pozici velitel čety nebo příslušník operační, plánovací nebo výcvikové skupiny/oddělení či vyšší pozice;

- zkušenosti s plánováním nebo řízením opatření k ženijní podpoře pohybu;

- účast na cvičeních (praktická i simulační) v rámci brigádního úkolového uskupení, popř. nasazení v zahraniční operaci, při které respondent řešil problematiku ženijní podpory činnosti vojsk.

Poznatky získané z rozhovorů byly hodnoceny analýzou a deduktivním prístupem. Metodami syntézy a indukce byly předloženy návrhy na zlepšení současného stavu ve zkoumané oblasti.

\section{FORMA A OTÁZKY ROZHOVORŮ S RESPONDENTY}

Rozhovor se vždy skládal z fází úvodu, vzestupu a upevnění kontaktu, vlastního jádra rozhovoru a poté závěru a ukončení. Důležité bylo navození přátelské a otevřené atmosféry, vzájemné důvěry k prezentování vlastních názorů a zkušeností, zdůraznění anonymity při prezentování výsledků rozhovoru a dodržování dalších zásad. ${ }^{\mathbf{5 , 6}} \mathrm{Na}$ začátku rozhovoru se dotázáním respondenta o průběhu jeho kariéry a absolvovaných cvičeních ověřilo, zda splňuje stanovená kritéria. Lze konstatovat, že převážná většina účastníků rozhovoru tyto nastavené minimální podmínky značnou měrou převyšovala. Poté byly položeny následující otázky:

1) Jaký význam přikládáte ženijní podpoře pohybu a jaké jsou kvalitativní (schopnost překonávat zátarasy a přemostovat překážky, poskytování vlastní ochrany apod.) a kvantitativní (množství potřebných ženijních sil a prostředků k podpoře jednotky, počet průchodů na četu/rotu/prapor apod.) požadavky na podporu pohybu od manévrujících jednotek (úroveň četa/rota/prapor/pluk/brigáda)?

5 BRECHTA, Bohumil, GRASSEOVÁ, Monika, ed. Efektivní rozhodování: analyzování, rozhodování, implementace a hodnocení. Brno: Edika, 2013. ISBN 978-80-266-0179-1.

6 ŠIROKÝ, Jan aj. Tvoříme a publikujeme odborné texty. Brno: Computer Press, 2011. ISBN 978-80-2513510-5. 
2) Jaké jsou vaše praktické zkušenosti a druhy výstupů (zpracovávaných dokumentů) v oblasti plánování a realizace ženijní podpory pohybu/přesunu vlastních vojsk a zkušenosti získané při účasti v mírových operacích?

3) Jaké dokumenty používáte při řešení problematiky ženijní podpory pohybu vojsk (plány, vyhodnocené poznatky a zkušenosti z misí a výcviku, standardní operační postupy apod.)?

4) Jaká je současná úroveň ženijních prostředků u vaší jednotky (útvaru) a jaké typy ženijních prostředků byste si představoval/a $\mathrm{k}$ plnění úkolů ženijní podpory pohybu ve prospěch manévrujících jednotek v boji (výbušné, mechanizační, vozidlové, nesené vojákem apod.)?

5) Uved'te názor na váhu (hodnotu) kritérií k posouzení uskupení ženijních sil a prostředků vytvářených $\mathrm{k}$ podpoře pohybu manévrujících jednotek:

- rychlost přesunu k provedení úkolu;

- průchodivost prostředku;

- rychlost splnění úkolu (zprůjezdnění cesty, odtarasení);

- odolnost prostředku;

- jiná kritéria.

Stejné hodnocení váhy pro více kritérií je možné. Hodnoty kritérií: 1 - nevýznamné; 2 málo významné; 3 - středně významné; 4 - významné; 5 - velmi významné.

\section{STANOVISKA RESPONDENTŮ K POLOŽENÝM OTÁZKÁM A JEJICH VYHODNOCENÍ}

\section{Otázka 1: Význam ženijní podpory pohybu, kvalitativní a kvantitativní požadavky}

Všichni respondenti uvedli, že řešení pohybu vlastních vojsk je jednou z nejdůležitějších, případně základních činností při plánování operace, a že ženijní podpora pohybu má obrovský význam, protože umožňuje provedení manévru vlastních vojsk. Také se vyskytoval názor, že ženijní podpora pohybu je kličová k umožnění provádění všech druhů operací.

V rámci kvalitativních požadavků na ženijní podporu pohybu zazněla následující stanoviska:

- nosnost útočných a doprovodných mostů musí odpovídat hmotnosti nejtěžších prostředků podporované jednotky a jejich délka musí umožňovat přemostění alespoň úzkých vodních toků (do $20 \mathrm{~m}$ dle polního rádu Všeob-̌̌-17);

- ženijní technika pohybující se $v$ prvních sledech vlastních vojsk musí disponovat přinejmenším stejným stupněm ochrany jako podporované jednotky; toto se týká zejména techniky pro překonávání zátarasů;

- ženijní jednotky musí mít $\mathrm{k}$ dispozici prostředky k poskytnutí vlastní ochrany, aby mohly působit samostatně $v$ taktické hloubce a odolávat silám neprítele;

7 VŠEOB-̌̌-1: Polní ř́ád Pozemních sil AČR. Praha: Ministerstvo Obrany ČR, 2002. 
- ženijní podpora musí umožňovat co nejvyšší rychlost překonávání zátarasů, aby se vlastní jednotky dostaly z rizikového místa co nejdř́ve;

- průchody zřizované ve prospěch prvosledových jednotek postačují $k$ jednosměrnému provozu, přičemž by měla šiřka průchodu odpovídat parametrům nejširšího prostředku podporované jednotky (šíŕka vozidla + šiřka pásů vozidla na každé straně), jednotky $v$ dalších sledech průchod rozšírí;

- ženijní jednotky musí být schopny odstraňovat překážky na komunikacích a musí mít ve své struktuře výbušné i nevýbušné odminovací prostředky (po použití výbušného odminovacího prostředku je třeba vytvořený průchod prověřit mechanickým prostředkem);

- mechanizované a tankové jednotky by měly mít ve své struktuře vlastní prostředky k prekenonávání zátarasů;

- překonání vodní překážky si vyžaduje podporu ženijních jednotek;

- ženijní jednotky brigádního úkolového uskupení musí disponovat shodným typem podvozků s podporovanými jednotkami $z$ důvodu totožné průchodivosti terénem ( $v$ rámci 4. BÚU ženijní technika na kolových podvozcích, v rámci 7. BÚU ženijní technika na pásových podvozcích);

- ženijní uskupení k podpoře pohybu by mělo mít stejnou, popř́padě vyšší pohyblivost (rychlost) než podporované jednotky;

- příslušníci obou brigád požadují prostředky ke zřizování průchodů ve prospěch pěších jednotek;

- $v$ rámci 4. BÚU se dají předpokládat vyšší požadavky na podporu pohybu než u 7. BÚU z důvodu nižší průchodivosti terénem jejích druhů techniky (kolový obrněný transportér Pandur).

Z výpovědí respondentů vyplynulo, že se při rešení otázek souvisejících s vhodností typů ženijních prostředků pro podporu pohybu musí vycházet $z$ parametrů podporované techniky a z úkolů, které se mohou plnit v rámci této role ženijní podpory.

Při působení v sestavě podporované jednotky jim bude tato ochrana zpravidla poskytnuta. Technika ženijní jednotky musí poskytovat alespoň základní stupeň ochrany proti prostředkům ničení nepř́tele. Při činnosti na předním okraji vlastních vojsk musí být tento stupeň ochrany co nejvyšší z důvodu velkého vystavení nepřátelské palbě.

Ženijní jednotky by měly mít dále ve své organizační struktuře zařazenou kombinaci výbušných a nevýbušných odtarasovacích prostředků ke zřizování průchodů v zátarasech o různé hloubce. Obdobné typy prostředkủ by měly mít $k$ dispozici i mechanizované (tankové) jednotky k zabránění co největšího zpomalení tempa vlastního postupu. $Z$ výše uvedených stanovisek dále vyplývá, že ruční způsob zřizování průchodů je zejména při ofenzivních činnostech nevyhovující z důvodu času potřebného ke zřízení průchodu a minimální ochrany př́slušníků ženijních jednotek při jejich zřizování.

Ženijní technika by měla disponovat stejnou, popř́padě vyšší mobilitou než podporované jednotky. Její činnost by měla fungovat na principu pilového grafu, kdy musí být ženijní technika schopna po splnění úkolu a přesunu manévrujících jednotek 
dojet podporované jednotky a prípadně je předstihnout k plnění dalšího úkolu. $V$ grafu 1 je znázorněn požadovaný princip činnosti mostního tanku. ${ }^{8}$

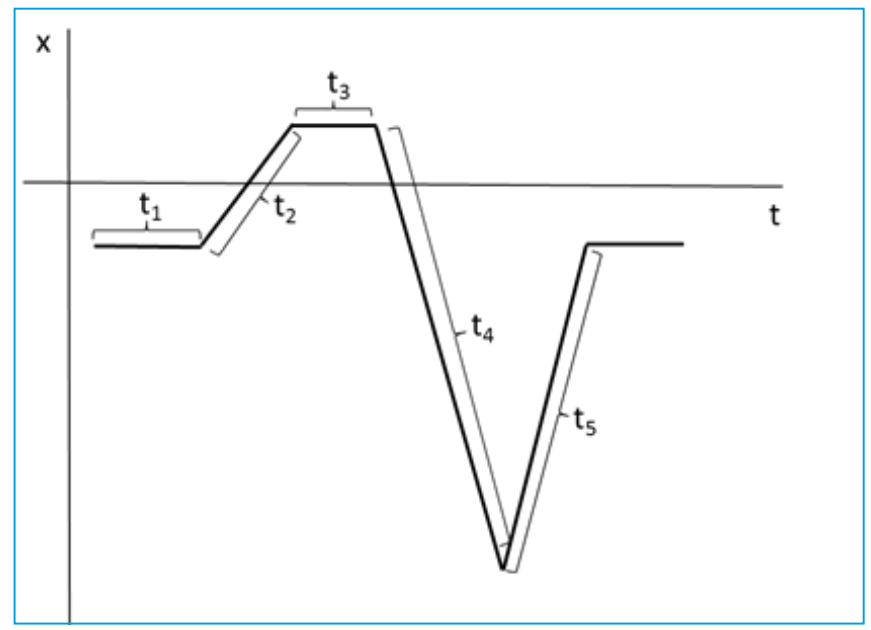

Graf č. 1: Znázornění principu činnosti mostního tanku

Kroky v jednotlivých časových okamžicích:

$\mathrm{t}_{1}$ - udržování tempa postupu v blízkosti čela proudu podporovaných jednotek;

$\mathrm{t}_{2}$ - přesun před čelo vlastních sil k překážce;

$\mathrm{t}_{3}$ - pokládání mostu přes překážku;

$\mathrm{t}_{4}$ - přejezd podporovaných sil přes most a následné zvednutí a naložení mostu;

$\mathrm{t}_{5}$ - dojetí do blízkosti čela proudu podporovaných jednotek.

Ke kvantitativním požadavkům zaujali respondenti tato stanoviska:

- $100 \%$ respondentů ze 4 . brn a 7. mb uvedlo, že současná velikost ženijní čety mechanizovaného/tankového praporu nedostačuje $k$ plnění úkolů v rámci bojové ženijní podpory činnosti vytvářených praporních úkolových uskupení;

- v rámci útočné činnosti je potřeba ženijních sil a prostředků velmi vysoká zvláště při útoku na předem vybudovanou obranu neprítele;

- při boji na zdrženou a manévrové obraně se dají předpokládat větší požadavky na ženijní podporu z důvodu ničení nepřítele v hloubce prostoru obrany a vyšších požadavků na manévr vlastních vojsk;

- manévrující rota by měla být schopná zř́idit 2 průchody $v$ zátarasech neprítele vlastními prostředky (nejčastěji se vyskytující hodnota od respondentů);

8 Na horizontální ose grafu je znázorněna časová osa ( $\mathrm{t}$ ) a na vertikální ose vzdálenost od čela podporovaných jednotek (x). Kladné hodnoty představují pozici před čelem vlastních sil směrem $\mathrm{k}$ nepřiteli, záporné hodnoty pak znázorňují pozici za čelem vlastních sil směrem od nepř́tele. Stupnice obou os má lineární charakter, výsledný graf je nelineární. 
- ženijní prostředky by měly umožňovat překonat zátarasy do 10 minut a zřizovat v nich průchody delší než 100 m (minimálně 150 m).

Z hlediska kvantitativních požadavků se objevovaly často velice rozdílné hodnoty např́klad v počtech zřizovaných průchodů na rotu. Průměrná hodnota činila 2 průchody. Objevil se i názor, že by každá četa měla být vybavena prostředkem pro zřízení průchodu v minovém poli. Rozdílnost hodnot vyplývá z faktu, že každá operace je specifická v množství faktorů a záleží na konkrétní situaci v daném místě a daném časovém okamžiku, jaké konkrétní požadavky směrem k ženijní podpoře činnosti vojsk vyvstanou. Dalším důvodem je, že se takovéto druhy norem nevyskytují v národních předpisech, přičemž jejich existence je nutná k tomu, aby velitelům poskytovaly vodítko při plánování operací.

Nedostatečná velikost ženijních jednotek zařazených v organizačních strukturách praporů 4. brn a 7. mb byla často diskutovaným tématem. Ženijní jednotky o velikosti četa a nižší, zařazené u praporů 4. brn a 7. mb, nevyhovují rozsahu požadavků na ně kladených. Na základě jejich organizační struktury je zřejmé, že se při jejich vytváření brala v úvahu jiná kritéria než kritéria $\mathrm{k}$ účinnému poskytování bojové ženijní podpory jejich činnosti. Současné ženijní čety mechanizovaných (tankového) praporů se skládají ze tří ženijních družstev, které nejsou schopné pokrýt požadavky praporu k vytváření všech typů ženijních uskupení v rámci bojové operace. Vzhledem k rozsahu problematiky (určování vhodné velikosti ženijní jednotky pro určité typy bojových operací a z těchto hodnot predikování určité průměrné velikosti ženijní jednotky) není cílem článku řešit organizaci a vybavení ženijních jednotek mechanizovaných (i tankového) praporů. Nicméně je potřebné $v$ dalších příspěvcích tuto problematiku neopomínat, protože velitelé praporů v rámci brigádního úkolového uskupení při současných cvičeních dostávají od ženijního praporu přidělenou ženijní jednotku v síle čety až zeslabené roty, a tím pádem je vytvoření všech ženijních uskupení potřebných k ženijní podpoře praporu reálné. Otázkou ovšem zůstává, kolik ženijních sil a prostředků poté zůstane $k$ dispozici veliteli brigádního úkolového uskupení k plnění brigádních úkolů v rámci ženijní podpory operace, pokud by takto byly posíleny všechny manévrující nebo prvosledové prapory.

\section{Otázka 2: Zkušenosti a výstupy v oblasti ženijní podpory pohybu}

Z analýzy rozhovorů s respondenty vyplynulo, že podporu pohybu v bojové operaci řešili téměř všichni při praktických cvičeních vojsk na území ČR nebo na zahraničních cvičeních (nejčastěji v Německu). Dále se touto problematikou zabývali při cvičeních s počítačovou podporou. Problematiku ženijní podpory pohybu řešili bud' z pozice velitele jednotky (útvaru), nebo př́slušníka štábu útvaru na různých úrovních (stupních) velení a řízení (četa až divize). V rámci ženijní podpory pohybu vojsk se procvičovaly úkoly:

- průzkum os přesunu;

- vytyčování objížděk;

- zřizování a udržování přepravišt' (např. v rámci cvičení Labe pod taktickým námětem násilného přechodu vodní překážky) organizované 15. žp;

- kalkulace množství ženijních sil a prostředků a návrh jejich použití; 
- navrhování složení uskupení ženijních sil a prostředků pro podporu pohybu; skupina k zabezpečení pohybu na stupni prapor; odřad k zabezpečení pohybu na stupni brigáda a jejich řizení v průběhu vedení operace.

Respondenty byla zdůrazněna spolupráce se zpravodajským střediskem štábu brigádního úkolového uskupení, kde se důstojníci ženijní specializace spolupodíleli na vyhodnocení průchodnosti terénu v prostoru operace. Jednalo se o vyznačení prostorů na mapovém podkladu s parametry průchodný (go area), obtižně průchodný (slow go area) a neprůchodný terén (no go area), vyhodnocení úseků terénu vhodných k pohybu vlastních vojsk (mobility corridors) a další úkoly.

Dále z rozhovorů vyplynulo, že se v rámci cvičení téměř neprocvičuje logistické zásobování bojujících jednotek. Také jsou časté prípady, kdy se část tématiky neprocvičuje hlavně z důvodu neexistence nebo zastaralosti určitých typů ženijní techniky, zejména ke zřizování průchodů $v$ zátarasech. Dále $z$ důvodu neochoty nebo nemožnosti tyto zátarasy při praktických cvičeních zřizovat.

Objevoval se často i názor, že na stupni mechanizovaný prapor není v průběhu cvičení z hlediska ženijní podpory činnosti vojsk mnohdy co plánovat, protože ženijní četa nedisponuje potřebnými schopnostmi. Nedochází tak často ani ke vzájemným cvičením rot a ženijní čety v rámci praporu. Výjimkou je 73. tankový prapor (73. tpr), kde je ženijní četa vybavena útočnými a doprovodnými mosty. Někteří respondenti uvedli, že se u velitelů manévrujících jednotek při cvičeních často vyskytovaly nedostatky z hlediska znalostí použití ženijních sil a prostředků a jejich schopností. Vyskytoval se i požadavek, aby ženijní uskupení $k$ podpoře pohybu měla vždy stejnou strukturu a prostředky, a tím pádem i schopnosti. Kde lze hledat důvody $\mathrm{k}$ těmto tvrzením, které odporují zásadám použití sil a prostředků bojové podpory? Přičina bude spočívat pravděpodobně v nízké úrovni spolupráce mezi mechanizovanými a ženijními jednotkami a v nízké úrovni znalostí velitelů manévrujících jednotek o schopnostech ženijních sil a prostředků.

Protože je každá operace jiná, nelze neustále vytvářet stejná uskupení k podpoře pohybu jak na úrovni praporního, tak brigádního úkolového uskupení. Struktura těchto uskupení se musí vytvářet na základě konkrétních podmínek operace (typ operace, stupeň velení, charakteristika terénu v zájmovém prostoru, ženijní opatření nepř́tele apod.) a z nich vyplývajících požadavků na ženijní podporu pohybu vojsk.

$\checkmark$ zahraničních operacích na podporu míru se pohyb vlastních vojsk řešil neustále. Úkoly ale spadaly do oblasti všeobecné ženijní podpory $\mathrm{k}$ zabezpečení volnosti pohybu vlastních sil. Mezi tyto úkoly patřily:

- kontrola, oprava a údržba komunikací;

- odhrnování sněhu, zpevňování úseků cest;

- patroly $k$ průzkumu a očistě cest od výbušných hrozeb ve spolupráci s pyrotechnickými jednotkami.

\section{Otázka 3: Dokumenty k problematice ženijní podpory pohybu}

Při plánování a řizení ženijní podpory pohybu se využívaly následující typy dokumentů a zdrojü:

- národní prèedpisy; 
- ženijní alianční doktríny;

- skripta (studijní texty) z Univerzity obrany;

- publikace vydané Centrem doktrín Velitelství výcviku Vojenské akademie ve Vyškově;

- standardní operační postupy útvarů a velitelství;

- závěry a doporučení ze cvičení - leassons learned;

- rozkaz nadřízeného a jeho př́loha ženijní podpora;

- takticko-technická data ženijních prostředků, které byly v průběhu operace $\mathrm{k}$ dispozici (pro provádění kalkulací);

- dříve zrušené předpisy (Metodická rukovět' velitele ženijní čety k vedení odborného výcviku).

Výše uvedený souhrn dokumentů a zdrojů není svým obsahem překvapující až na poslední položku. Z jakého důvodu někteří příslušníci AČR využívají při své činnosti již zrušené předpisy? Důvod Ize hledat ve vyřazování určitých předpisů bez vydání jejich adekvátní náhrady. Problém může být způsoben nedostatečným počtem důstojníků $v$ přislušných organizačních strukturách AČR. Další př́íina může spočívat v současných legislativních restrikcích a požadavcích na nové předpisy. Platné předpisy tak mnohdy neobsahují údaje, které by pokrývaly současné požadavky velitelů a příslušníků štábů $v$ průběhu plánování a vedení operace.

Ve většině útvarů a velitelstvích jsou vytvářeny standardní operační postupy obsahující plán konkrétní činnosti příslušníků štábu a velitelů jednotek při plánování a vedení operace. Jsou schvalovány velitelem útvaru nebo náčelníkem štábu. Na některých praporech ale chybí jejich část zabývající se poskytováním ženijní podpory v průběhu operace. Tato skutečnost může být způsobena podceňováním důležitosti ženijní podpory činnosti vojsk v průběhu operace, zahlceností štábu praporu jinými úkoly, ale i malou aktivitou příslušníka ženijní specializace ve štábu praporu. Z odpovědí respondentů Ize usuzovat, že úroveň zpracovaných standardních operačních postupů je v rámci jednotlivých útvarů značně odlišná. Problematiku standardních operačních postupů řeší Pub-53-01-03 Štábní práce v operacích ${ }^{9}$, která obsahuje společná témata jejich tvorby na základě standardizační dohody STANAG 2467. Forma a rozsah ale nejsou žádnou normou stanoveny.

\section{Otázka 4: Současná úroveň a navrhované typy ženijních prostředků k podpoře pohybu}

Pro vyvozování závěrů a vytváření doporučení v řešené problematice je nezbytné znát současnou úroveň ženijních prostředků k podpoře pohybu nacházejících se v sestavách útvarů AČR. V rámci odpovědí na tuto část otázky zazněla následující stanoviska:

- u 15. žp i 4. brn a 7. mb (výjimkou je pouze 73. tpr) schází odtarasovací technika mechanické i výbušné odminovače;

- chybí pancéřovaná technika, která by mohla plnit úkoly pod palbou nepř́tele; ženijní technika nedisponuje odolností proti minám;

9 Pub-53-01-3. Štábní práce v operacích 2. část. Hlavní zásady tvorby stálých operačních postupů, operačních (bojových) dokumentů a hlášení. Vyškov: Správa doktrín ŘeVD, 2008. 
- ženijní technika se vyznačuje nedostatečnou průchodivostí terénem, není tudíž schopna plně podporovat manévrující jednotky (7. mb);

- kolový obrněný transportér Pandur v ženijní úpravě nedisponuje schopnostmi $k$ účinné podpoře pohybu; ve své podstatě oproti verzi pro mechanizované jednotky obsahuje navíc pouze přihrádky na rozbušky a náloživo;

- při vytváření uskupení k podpoře pohybu ze sil a prostředků ženijního praporu nejsou tato uskupení př́liš pohyblivá, vyznačují se nízkou rychlostí pohybu i průchodivostí terénem;

- současná ženijní technika zařazená u 4. brn a 7. mb je značně poruchová;

- pontonová mostová souprava naplňuje soudobé požadavky na zřizování a udržování přepravišt' a jedná se o spolehlivý prostředek.

Z výše uvedených odpovědí, které byly z větší části konzistentní u všech respondentů, vyplývají závažné skutečnosti týkající se stavu ženijní techniky k podpoře pohybu. U mechanizovaných a ženijních jednotek chybí základní typy techniky ke zřizování průchodů ve výbušných zátarasech a ražení průchodů v nevýbušných zátarasech pod palbou neprítele. Ženijní technika u 7. mb není schopna držet tempo pohybu s podporovanými silami v terénu, a tím pádem nemůže účinně poskytovat ženijní podporu činnosti vojsk.

Problematická je i situace ohledně ženijní verze kolového obrněného transportéru Pandur, která svojí konfigurací nenabízí žádné schopnosti využitelné mechanizovanými jednotkami k podpoře pohybu. Mezi jediné výhody tohoto prostředku patři schopnost udržovat rychlost pohybu s podporovanými jednotkami a poskytovat požadovaný stupeň ochrany převážené osádce. Z výše uvedených důvodů se mnohými příslušníky označuje jako „lepší autobus".

Požadavky na typy ženijních prostředků k podpoře pohybu byly následující:

- nevýbušné prostředky $\mathrm{k}$ podpoře pěší jednotky (lávky k překonávání úzkých řek a dalších překážek s únosností pro vojáka s výstrojí);

- výbušné prostředky k podpoře pěší jednotky (vystřelovací odminovací prostředky ke zřízení průchodu v protipěchotním zátarasu);

- přídavné odminovací odsuvné zařízení ke zřízení průchodu v povrchově zřízeném minovém poli na zpevněném terénu nebo komunikaci (pro 4. brn);

- návěsné odminovací zařízení, které vyrývá miny před pásy a odhrnuje je na jejich vnější stranu na bojové vozidlo pěchoty BVP-2 (pro 7. mb);

- návěsná radlice ke zřizování průchodů v minových polích a zahrnování nálevek;

- výbušné (raketové) odminovače;

- zařízení k označování zřízených průchodů v minových polích bez nutnosti sesednutí z vozidla (land marking system);

- ženijní tank s radlicí, rypadlem, navijákem umožňujícím samo vyproštění a odtarasování (odsun nevýbušných překážek) s taženým výbušným odminovačem k podpoře jednotek v prvním sledu;

- útočné mosty k překonávání suchých i vodních překážek s horizontálně pokládaným mostem (nejlépe na tankovém podvozku T-72);

- doprovodné mosty (pancéřovaná verze mostního automobilu);

- moderní obojživelné přepravní prostředky;

- pancéřované stroje na zemní práce. 
Většina respondentů se shodla, že jsou potřeba všechny typy ženijních prostředků uvedených v textu otázky, nicméně záleží na mnoha faktorech, které ovlivňuji jejich použití. Mezi tyto faktory patří: druh operace, činnost nepřítele, místo v sestavě manévrující jednotky (v prvním sledu, za prvosledovými jednotkami), stav infrastruktury, charakter terénu v bojové zóně, počasí a další.

Polovina oslovených důstojníků ženijního vojska v rámci odpovědi zmínila problém, zda pořídit multifunkční nebo jednoúčelové prostředky. Několik respondentů bylo pro jednoznačnou volbu jednoúčelových ženijních strojů z důvodu vyšší výkonnosti na určitý úkol, méně náročnému výcviku obsluhy (strojníků) ve srovnání s multifunkčním prostředkem a nižší pořizovací ceny. Zbývající část respondentů byla oproti tomu jednoznačně pro multifunkční prostředky z důvodu nižší potřeby počtu vozidel na celé spektrum plněných úkolů, z tohoto důvodu i lepšímu logistickému zabezpečení přepravy techniky a celkové úspoře sil a prostředků. Při hlubší diskuzi o tomto problému se ale většina respondentů shodla, že vždy záleží na situaci, zda se jedná o podporu vojsk v dotyku s nepř́telem (kdy se nedá nikdy dopredu přesně předpovědět jakými prostředky a způsobem na nás bude útočit a na jaké překážky narazíme), kdy jsou vhodnější multifunkční prostředky, nebo o podporu na vyžádání za prvosledovými jednotkami (kdy se na základě stanoveného úkolu vysílá konkrétní ženijní technika z vytvořených uskupení k podpoře pohybu), kdy jsou vhodnější jednoúčelové prostředky.

\section{Otázka 5: Váha kritérií posuzování ženijních prostředků k podpoře pohybu}

Cílem otázky bylo zjistit váhy obecných kritérií k posuzování ženijních prostředků k podpoře pohybu, ze kterých se dají predikovat požadované parametry a na jejichž základě je možné určit konkrétní typy prostředků k podpoře pohybu v jednotlivých uskupeních. Při poskytování ženijní podpory pohybu se v bojové operaci budou zpravidla vytvářet uskupení ženijních sil a prostředků, jejichž úkolem bude podporovat určené jednotky. V podmínkách AČR se bude jednat o doprovodnou skupinu (DSk), skupinu k zabezpečení pohybu (SkZP) a odřad k zabezpečení pohybu (OZP).

Doprovodnou skupinu si budou vyčleňovat velitelé na úrovni rota a do tohoto uskupení by měli zařazovat zpravidla prostředky ze své jednotky (vozidla s buldozerovým zařizením, odminovací prostředky, automobily pro přepravu stavebního materiálu apod.). Současná praxe u vojsk je ovšem taková, že jsou do doprovodné skupiny začleňována celá ženijní družstva. Příčinu tohoto stavu Ize najít v nevybavenosti ženijními prostředky u mechanizovaných jednotek (výjimku tvoří pouze 73. tpr s návěsným odminovacím zařízením KMT- 6 a výbušným odminovačem zařazenými u tankových rot).

Na stupni prapor by se měla vyčleňovat SkZP ze sil a prostředků ženijní čety a na stupni brigáda OZP z přiděleného ženijního praporu. Tato uskupení se při hrozbě střetu s nepř́telem budou pohybovat vždy za prvosledovými jednotkami.

V tabulce 1 jsou znázorněny průměrné hodnoty váhy obecných kritérií k posuzování ženijních prostředků k podpoře pohybu, získané z odpovědí jednotlivých respondentů. 


\begin{tabular}{|l|c|c|}
\hline \multirow{2}{*}{\multicolumn{1}{|c|}{ Kritérium }} & \multicolumn{2}{|c|}{ Míra vlivu } \\
\cline { 2 - 3 } & DSk & SkZP/OZP \\
\hline $\begin{array}{l}\text { Rychlost přesunu k prove- } \\
\text { dení úkolu }\end{array}$ & 4,19 & 4,04 \\
\hline Průchodivost prostředku & 4,54 & 3,38 \\
\hline $\begin{array}{l}\text { Rychlost splnění úkolu } \\
\text { (zprůjezdnění cesty/ odta- } \\
\text { rasení) }\end{array}$ & 4,74 & 4,04 \\
\hline Odolnost prostředku & 4,21 & 3,14 \\
\hline
\end{tabular}

Tabulka 1 Váhy kritérií kladené na ženijní prostředky k podpoře pohybu

Na prvním místě u doprovodné skupiny zvolili respondenti kritérium rychlost splnění úkolu. V rámci podpory pohybu se v bojových situacích bude jednat nejčastěji o zřizování průchodů v zátarasech, úpravu cest, překonávání suchých a vodních překážek a činnost proti minám zejména $v$ zastavěném prostoru. Jedná se o kritérium nejvyšší důležitosti pro velitele podporovaných jednotek. $V$ odpovědích především u důstojníků mechanizovaného vojska mnohdy zaznělo, že pro ně není podstatné, jaký konkrétní prostředek podporuje jejich činnost, ale zda je schopen splnit daný úkol v požadovaném čase a kvalitě. U SkZP/OZP byla tomuto kritériu přisouzena menší, nicméně stále velice významná váha (první a druhé pořadí společně s rychlostí přesunu k zásahu).

Na druhém místě se u DSk umístilo kritérium průchodivost prostředku, taktéž s hodnocením jako velice významného. U DSk se předpokládá pohyb terénem společně s podporovanou jednotkou, zatímco SkZP/OZP budou zpravidla ve větší míře využívat stávající silniční sítě. Tomu svědčí i ohodnocení tohoto kritéria, které je nižší než u DSk s hodnocením středního významu.

Jako třetí, ale významné kritérium, se u DSk umístila odolnost prostředku. Často se vyskytovalo stanovisko, že by ženijní prostředky měly mít stejnou míru odolnosti jako podporované prostředky. Někteří respondenti se vyjádřili, že by měly mít i vyšší stupeň odolnosti z důvodu jejich extrémního vystavení všem dostupným prostředkům ničení při zřizování průchodů v neprátelských zátarasech, kdy se musí předpokládat, že každý zátaras bude kryt palbou. U SkZP/OZP získalo toto kritérium nejnižší ohodnocení, vzhledem ke stupnici jako středně významné. Př́činou je jejich nižší očekávané vystavení neprátelské palbě ve srovnání s DSk. Nicméně převážná většina respondentů uvedla, že by měly ženijní prostředky, působící v bojových operacích, poskytovat alespoň základní stupeň ochrany proti palbě z ručních zbraní.

Na posledním místě, ale jako významné, se u DSk umístilo kritérium označené jako rychlost přesunu k provedení úkolu. Vyplývá to z charakteru činnosti DSk, které se pohybují v sestavě podporované jednotky, a očekává se, že s ní budou udržovat tempo. $\checkmark$ případě výskytu překážky by mělo trvat $v$ řádu minut, než se ženijní prostředky dosta- 
nou na pozici k plnění úkolu. U SkZP/OZP bylo toto kritérium hodnoceno téměř stejnou hodnotou a umístilo se $v$ rámci těchto uskupení na prvním až druhém pořadí zároveň.

Respondenti měli možnost v rámci hodnocení uvedených kritérií navrhnout vlastní. Nejčastěji jimi zmiňovaným dalším kritériem byla uváděna interoperabilita s hodnotou váhy 3,4. Schopnost spolupůsobit s aliančními armádami je bezesporu velice důležitým aspektem současných operací, které mají zpravidla mezinárodní charakter. Dalšími zmiňovanými kritérii byly nahraditelnost ženijního prostředku (hodnota váhy 4) a jeho opravitelnost v polních podmínkách (hodnota váhy 3).

\section{ZOBECNĚNÍ POZNATKU゚ A STANOVENÍ DOPORUČENÍ}

Z rozhovorů s respondenty vyplynulo, že čím blíže se budou ženijní prostředky pohybovat k úrovni přední linie, tím větší požadavky na ně budou kladené z hlediska rychlosti plnění úkolů souvisejících s podporou pohybu. Příslušníci 4. brn a 7. mb zpravidla neřešili, jaký konkrétní ženijní prostředek bude plnit úkoly v jejich prospěch. Jejich zájmem je co nejrychlejší opuštění prostoru ohroženého palbou nepř́itele při výskytu překážky ve směru jejich plánovaného manévru.

Dalším důležitým požadavkem byla samostatnost uskupení ženijních sil a prostředků při plnění úkolů z hlediska jejich ochrany proti činnosti nepř́tele. Ve své sestavě by tudíž měla mít ženijní uskupení zařazenu bojovou techniku, popřípadě by konfigurace ženijní techniky měla obsahovat věžový komplet k zabezpečení palebné podpory.

U 4. brn je kladen větší důraz na ženijní prostředky k podpoře pohybu pěších jednotek (nesené výbušné odminovače) oproti jednotkám 7. mb z důvodu taktického použití kolového obrněného transportéru Pandur a faktu, že nedisponuje pancéřovanou zbraňovou stanicí oproti BVP-2. Jeho použití tak bude spočívat spíše v podpoře pěchoty $z$ větších vzdáleností a využívání zpevněných komunikací při přesunech.

Podpora mechanizovaných a tankových jednotek bude všeobecně vyžadovat komplexnější řešení tvořené kombinací výbušných a nevýbušných odminovačů, mostních prostředků a zemních strojů. Při zřizování průchodů ve výbušných zátarasech je výhodné používat metodu US Army - RPMR:

- Reduce - proražení průchodu; obvykle výbušný odminovač;

- Proof - prověření průchodu mechanickým prostředkem;

- Mark - vyznačení průchodu ženijním družstvem, popřípadě může být tento krok spojen s předcházejícím, pokud je ženijní prostředek vybaven zařízením pro označování zř́zených průchodů v minových polích;

- Redundancy - záložní prostředek k provedení prvních dvou bodů.

Na základě zobecnění získaných poznatků a požadavků na ženijní techniku k podpoře pohybu jsou $v$ uvedené tabulce 2 představeny možné typy ženijní techniky $v$ závislosti na konkrétních úkolech ženijní podpory pohybu plněných v bojových operacích a druhu uskupení ženijních sil a prostředků k podpoře pohybu. $V$ tabulce se vícekrát vyskytují následující kategorie ženijní techniky v jednotlivých druzích uskupení ženijních sil a prostředků vyčleňovaných $\mathrm{k}$ podpoře pohybu: 


\begin{tabular}{|c|c|c|c|c|c|c|c|}
\hline \multirow[b]{2}{*}{$\begin{array}{c}\text { Ženijní } \\
\text { uskupení } \\
\text { pro } \\
\text { podporu } \\
\text { pohybu }\end{array}$} & \multicolumn{7}{|c|}{ Úkoly ženijní podpory pohybu v boji } \\
\hline & 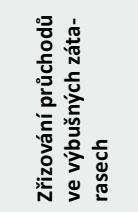 & 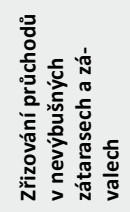 & 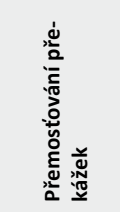 & 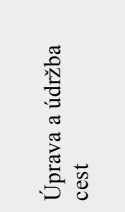 & 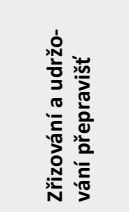 & 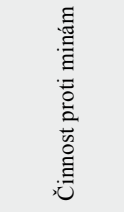 & 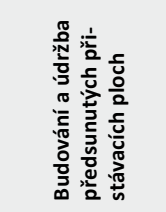 \\
\hline DSk & $\begin{array}{c}\text { BVP s odmino- } \\
\text { vací radlicí } \\
\text { (7. mb) } \\
\text { KOT s odsuv- } \\
\text { ným zařizením } \\
\text { (4. brn) } \\
\text { Výbušné } \\
\text { odminovače } \\
\\
\text { Ženijní } \\
\text { tanky } \\
\text { (73. tpr) } \\
\end{array}$ & $\begin{array}{c}\text { Návěsná } \\
\text { buldozerová } \\
\text { zařizení } \\
\text { Navijáky } \\
\\
\text { Ženijní } \\
\text { tanky } \\
\text { (73 tpr) }\end{array}$ & $\begin{array}{l}\text { Útočné } \\
\text { mosty }\end{array}$ & $\begin{array}{c}\text { Návěsná } \\
\text { buldozerová } \\
\text { zařízení } \\
\text { Ženijní } \\
\text { tanky } \\
\text { (73. tpr) }\end{array}$ & $\begin{array}{c}\text { Útočné } \\
\text { mosty } \\
\text { Obrněné } \\
\text { ženijní stroje } \\
\text { Obojživelné } \\
\text { přepravní } \\
\text { prostředky }\end{array}$ & $\begin{array}{l}\text { Odminovací } \\
\text { radlice } \\
\text { Odsuvná } \\
\text { zařizení } \\
\text { Výbušné } \\
\text { odminovače } \\
\text { (i pro pěší } \\
\text { jednotky) } \\
\text { Ženijní } \\
\text { tanky } \\
\text { (73. tpr) }\end{array}$ & $\begin{array}{l}\text { Návěsná buldoze- } \\
\text { rová zařízení } \\
\text { Ženijní tanky } \\
\text { (73. tpr) }\end{array}$ \\
\hline SkZP & $\begin{array}{c}\begin{array}{c}\text { BVP s odmino- } \\
\text { vací radlicí } \\
\text { (7. mb) } \\
\text { KOT-Ž s odsuv- } \\
\text { ným zařizením } \\
\text { (4. brn) } \\
\text { Výbušné } \\
\text { odminovače }\end{array}\end{array}$ & $\begin{array}{c}\text { Obrněné } \\
\text { ženijní stroje }\end{array}$ & $\begin{array}{c}\text { Doprovodné } \\
\text { mosty }\end{array}$ & $\begin{array}{c}\text { Obrněné } \\
\text { ženijní stroje } \\
\text { Obrněná } \\
\text { přepravní } \\
\text { technika } \\
\text { (na materiál) }\end{array}$ & $\begin{array}{c}\text { Doprovodné } \\
\text { mosty }\end{array}$ & $\begin{array}{l}\text { Odminovací } \\
\text { radlice } \\
\text { Odsuvná } \\
\text { zařizení } \\
\text { Výbušné } \\
\text { odminovače } \\
\text { Mechanická } \\
\text { iniciační zař́- } \\
\text { zení (rollery) }\end{array}$ & $\begin{array}{l}\text { Obrněné ženijní } \\
\text { stroje }\end{array}$ \\
\hline OZP & $\begin{array}{l}\text { Odminovací } \\
\text { radlice } \\
\text { Odsuvná } \\
\text { zařizení } \\
\\
\text { Výbušné } \\
\text { odminovače }\end{array}$ & $\begin{array}{l}\text { Obrněné } \\
\text { ženijní stroje }\end{array}$ & $\begin{array}{l}\text { Doprovodné } \\
\text { mosty } \\
\text { Přepravníky } \\
\text { mostů }\end{array}$ & $\begin{array}{c}\text { Obrněné } \\
\text { ženijní stroje } \\
\text { Obrněná } \\
\text { přepravní } \\
\text { technika } \\
\text { (na materiál) }\end{array}$ & $\begin{array}{l}\text { Doprovodné } \\
\text { mosty } \\
\text { Obrněné } \\
\text { ženijní stroje }\end{array}$ & $\begin{array}{l}\text { Odminovací } \\
\text { radlice } \\
\text { Odsuvná } \\
\text { zařizení } \\
\text { Výbušné } \\
\text { odminovače } \\
\text { Mechanická } \\
\text { iniciační zař́- } \\
\text { zení (rollery) }\end{array}$ & $\begin{array}{l}\text { Obrněné ženijní } \\
\text { stroje }\end{array}$ \\
\hline
\end{tabular}

Tabulka č. 2: Možné typy ženijní techniky k podpoře pohybu v boji 
- ženijní tank - $5 \times$ u DSk (nenachází se v sestavách ženijních jednotek);

- obrněné ženijní stroje - $4 \times$ × U SkZP/OZP (nenachází se v sestavách ženijních jednotek);

- útočné mosty $-2 \times$ u DSk (zastaralá verze pouze u 73. tpr);

- doprovodné mosty $-2 \times$ u SkZP/OZP (v sestavě 15 . žp);

- výbušné odminovače $-2 \times$ u DSk/SkZP/OZP (zastaralá verze pouze u 73. tpr);

- návěsná buldozerová zařízení $-3 \times$ u DSk ( $v$ sestavách jednotek AČR);

- odminovací radlice $-2 \times$ u DSk/SkZP/OZP (nenachází se v sestavách ženijních jednotek);

- odsuvná zařízení - 2 × u DSk/SkZP/OZP (pouze jeden exemplář v sestavě 15. žp).

Z výše uvedeného přehledu je vzhledem $k$ četnosti výskytu konkrétních typů ženijní techniky zřejmé, že by se $v$ následujících letech měly pořizovat především ženijní tanky a obrněné ženijní stroje, které se v sestavách ženijních jednotek nenachází.

\section{ZÁVĚR}

Při pořizování ženijních prostředků je třeba vždy brát v úvahu názory a stanoviska uživatelů. Na jedné straně př́slušníkủ ženijní specializace, kteří s těmito prostředky budou zacházet, na straně druhé názory a stanoviska velitelů podporovaných jednotek, v jejichž prospěch se plní úkoly v rámci ženijní podpory pohybu, zejména pokud se bude jednat o úkoly v oblasti bojové ženijní podpory. Součinnost je důležitá k tomu, aby mohly ženijní jednotky násobit bojovou hodnotu vlastních sil účinnou podporou.

Dále je nutné při pořizování nových prostředků řešit i pravidla jejich použití a jejich vliv na oblast velení a řízení především u výbušných odminovačů, kde budou platit rozsáhlé restrikce $k$ jejich použití z důvodu vedlejších ničivých účinků používaných výbušnin. PInění úkolů v rámci ženijní podpory pohybu vojsk bude také vyžadovat rozsáhlou logistickou podporu.

Pořizení nových moderních ženijních prostředků pro 15. žp, 4. brn a 7. mb je velice důležité $\mathrm{k}$ tomu, aby se mohla rozvíjet taktika použití ženijních sil a prostředků a nedocházelo k odtržení výcviku ženijních a mechanizovaných jednotek, k nedostatku (absenci) součinnostních cvičení a z toho plynoucímu úpadku reálných schopností a ochoty spolupráce.

Předmětem dalšího výzkumu by mělo být provedení výběru ženijní techniky $\mathrm{k}$ plnění úkolů v rámci ženijní podpory činnosti jednotek AČR. Na základě analyzovaných potřeb na ženijní techniku $k$ podpoře pohybu a vzhledem ke stanoveným kritériím je nutné zapracovat návrh struktury ženijní jednotky mechanizovaného praporu s vybranou technikou $k$ podpoře pohybu. Tato jednotka by měla mít schopnosti plnit požadované úkoly podpory pohybu mechanizovaného praporu a také vyčleňovat síly a prostředky k vytváření uskupení pro potřeby praporu v operaci. 
Autoři: $\quad$ kpt. Ing. Ota Rolenec, narozen 1983, v letech 2002-2005, 2008-2010 absolvent bakalářského a magisterského studijního programu Velitel ženijních jednotek - manažer na Fakultě ekonomiky a managementu Univerzity obrany. Od roku 2015 student kombinovaného doktorského studijního oboru Vojenský management studijního programu Ekonomika a management. Aktuálně zastává pozici Zástupce náčelníka štábu 153. ženijního praporu. Zabývá se problematikou ženijní podpory pohybu vojsk $v$ bojových operacích.

plk. Ing. Jan Kyjovský, Ph.D., nar. 1965, absolvoval Vysokou vojenskou školu pozemního vojska ve Vyškově, obor velitelsko-inženýrský ženijní (1988). Zastával ženijní velitelské a štábní funkce u mechanizovaných jednotek pozemních sil (četa, rota, prapor, pluk, divize). V roce 1999 se zúčastnil mise SFOR II $\checkmark$ Bosně a Hercegovině na pozici ženijního náčelníka mechanizovaného praporu. V letech 2001-2003 pracoval ve štábu 1. mechanizované divize v Brně, $v$ letech 2003-2005 pracoval na Ředitelství výcviku a doktrín ve Vyškově. Od roku 2005 pracuje ve vojenském školství - vedouci skupiny řízení zabezpečení podpory (2005-2014), zástupce vedouciho katedry (2014-2015). Od roku 2015 do současnosti působí jako vedoucí katedry ženijní podpory Univerzity obrany Brno.

Doc. Ing. Jaroslav Zelený, CSc. (plk.v.v.), nar. 1948, VAAZ Brno, zastával šest let velitelské funkce $v$ ženijním vojsku (četa, rota, prapor), sedm let na operačním velitelství (Velitelství ZVO), od r. 1979 ve vojenském školství na VAAZ Brno. Od r. 1989 zástupce vedoucího katedry operačního použití ženijního vojska a ženijního zabezpečení. Se vznikem Univerzity obrany pracoval jako o.z. a odborný asistent Ústavu operačně taktických studií a od r. 2007 je príslušníkem katedry řízení ženijního zabezpečení boje FEM UO. Je předsedou oborové rady DSP "Teorie obrany státu", členem oborové rady DSP „Vojenský management" a členem redakční rady sborníku „Ekonomika a management". V rámci své vědecko-pedagogické činnosti se zaměruje na problematiku použiti jednotek ženijního vojska v bojových a nebojových operacích, rízení ženijního zabezpečení a velení ženijnímu vojsku. $V$ této oblasti je také autorem či spoluautorem mnoha odborných publikací.

pplk. Ing. Tibor Palasiewicz, Ph.D., narozen v roce 1975, po ukončení vysokoškolského vzdělání na Vysoké vojenské škole ve Vyškově v roce 2000 byl zařazen u ženijního vojska na různých velitelských a štábních funkcích, naposledy u Velitelství 4. brigády rychlého nasazení. $V$ roce 2008 nastoupil do funkce odborného asistenta katedry ženijní podpory Univerzity obrany, kde působí doposud. $V$ roce 2015 dokončil studium doktorského studijního programu. Jeho specializace je zaměřena do oblastí použití jednotek ženijniho vojska v operacích, zatarasování a odstraňování výbušných prostredků. 
Jak citovat: ROLENEC, Ota and Jan KYJOVSKÝ, Jaroslav ZELENÝ, Tibor PALASIEWICZ. Výsledky výzkumu k problematice ženijní podpory pohybu $\mathrm{v}$ bojových operacích. Vojenské rozhledy. 2017, 26 (3), 52-67. DOI: 10.3849/23362995.26.2017.03.052-067. ISSN 1210-3292 (print), 2336-2995 (on-line). Available at: www.vojenskerozhledy.cz 


\section{Česká republika a „nová“ Společná bezpečností a obranná politika EU: Čas zásadních rozhodnutí}

\section{The Czech Republic and „New" EU Common Security and Defense Policy: Time of Crucial Decisions}

\section{Vilém Kolín}

Abstrakt: Ve stínu razantní proměny bezpečnostního prostředí se realizuje dlouho odmítaná myšlenka vícerychlostní Evropy v obranné spolupráci. Jak si v tomto kontextu stojí Česká republika? Je pripravena se adaptovat a učinit obranu jednou z vládních priorit, nebo bude jen pasivně přihližet okolnímu dění a $v$ určitém momentě strpí další intervenci nebo okupaci jiné mocnosti? Článek nastiňuje několik praktických doporučení v oblasti budování vojenských schopností, vyzbrojování, obranného výzkumu, průmyslu a trhu, které by pro Českou republiku mohly být $v$ tomto procesu vodítkem.

Abstract: In the shadow of the profound transformation of the security environment, the long rejected idea of a multi-speed Europe in defence is taking shape. What is the Czech Republic's stance in this context? Is it ready to adapt and make defence one of the government's priorities, or will it only passively observe the events around it and at some point tolerate another intervention or occupation of another power? The article outlines several practical recommendations to the Czech Republic in the area of military capabilities, armaments, defence research, defence industry and market, which could provide guidance in this process.

Klíčová slova: Evropská unie; Evropská komise; Česká republika; společná bezpečnostní politika; společná obranná politika.

Keywords: European Union; European Commission; Czech Republic; Common Security Policy; Common Defence Policy. 


\section{ÚVODEM}

Základem tohoto článku bylo stanovisko vypracované ke Kulatému stolu Národního konventu o EU na téma budoucnost Společné bezpečností a obranné politiky EU, který se konal 19. května 2017 v Praze v Lichtenštejnském paláci). Názory a doporučení obsažené v tomto článku jsou autora a nepředstavují pozici Evropské obranné agentury (EDA), kde autor v současnosti působí.

\section{GEOPOLITICKÁ SITUACE}

Evropský i globální kontext se zásadně mění: v roce 2016 Evropská Unie přijala novou Globální strategii zahraniční a bezpečnostní politiky, načež Evropská komise bezprecedentně vstoupila do budování vojenských schopností, kdy v rámci Evropského obranného akčního plánu (European Defence Action Plan - EDAP) nabízí v rámci tzv. Okna výzkumu (Research Window) 100\% finančního krytí do výše 90 mil. Euro (do roku 2019) a 500 mil. Euro po roce 2020 na společné projekty obranného výzkumu a v rámci tzv. Okna schopností (Capability Window) 500 mil. Euro na roky 2019 a 2020 a 1 mld. Euro po roce 2020 na programy v oblasti společného pořízení vojenského vybavení, přičemž se jedná o doplňkové financování (např. 20\% na vývoj prototypů vojenských systémů) k národním př́spěvkům, v některých případech však až do výše $100 \%{ }^{1} \mathrm{~S}$ plánovaným ustavením Stále strukturované spolupráce (Permanent Structured Cooperation - PESCO) se realizuje dlouho odmítaná myšlenka vícerychlostní Evropy v obranné spolupráci. ${ }^{2}$ Implementace Společné deklarace Evropské unie (EU) a Severoatlantické aliance (NATO) vede $\mathrm{k}$ dosud nevídané spolupráci mezi oběma organizacemi. ${ }^{3} \mathrm{~S}$ odchodem Velké Británie z EU se Francie pasuje do role evropského lídra v obranných otázkách a spolu s Německem, které vzhledem k mnoha poválečným omezením, nemá jinou možnost, něž poevropštit svoji obranu, má ambici být opět motorem evropské integrace, tentokrát v tak citlivé otázce jakou je evropská obrana. Zároveň z USA nová Trumpova administrativa vysílá jasný signál evropským spojencům, že obrana je především jejich záležitost a Putinovo Rusko čeká na další vhodnou príležitost k obnovení studenoválečných pozic.

1 Viz European Defence Action Plan: Towards a European Defence Fund, Brusel, 30. listopadu 2016. Dostupné z http://europa.eu/rapid/press-release_IP-16-4088_en.htm; A European Defence Fund: $€ 5.5$ billion per year to boost Europe's defence capabilities, Brusel, 7. června 2017, a související odkazy. Dostupné z http://europa.eu/rapid/press-release_IP-17-1508_en.htm.

2 Viz COELMONT, Jo. Permanent Sovereign COoperation (PESCO) to Underpin the EU Global Strategy. Security Policy Brief. Egmont Institute. Prosinec 2016, č. 80, s. 1-3. Dostupné z http://www.egmontinstitute.be/ wp-content/uploads/2016/12/SPB80.pdf.

3 Viz EU-NATO Joint Declaration, Varšava, 8. července 2016. Dostupné z http://www.consilium.europa.eu/ en/press/press-releases/2016/07/08-eu-nato-joint-declaration/; EU-NATO cooperation: Council adopt conclusions to implement Joint Declaration, Brusel, 6. prosince 2016. Dostupné z http://www.consilium. europa.eu/en/press/press-releases/2016/12/06-eu-nato-joint-declaration/. 
S rostoucím migračním, ekonomickým i sociálním tlakem, a ruku v ruce jdoucím euroskeptismem a novým nacionalismem, by se bez nadsázky dalo říci, že Evropa prožívá jedno z nejkritičtějších období od konce Studené války, dobu, která se v mnoha ohledech podobá mezidobí vymezené dvěma světovými válkami.

\section{A ČESKÁ REPUBLIKA}

Jak si v tomto kontextu stojí Česká republika? Je připravena se adaptovat a navzdory relativně slabé podpoře veřejnosti a složité historické zkušenosti učinit obranu jednu z vládních priorit s odpovídajícím zdrojovým zajištěním tak, jako to Masarykovo Československo učinilo v meziválečném období? Nebo Česká republika bude jen pasivně přihližet dění okolo sebe a v určitém momentě bude bez boje připravena strpět další intervenci nebo okupaci jiné mocnosti?

Jakkoliv žádoucí je odpovědět „ano“ na první otázku, poslední čísla bohužel jasně hovoří ve prospěch druhé varianty. Za rok 2016, Česká republika investovala do zajištění své obrany jen 0,97 \% HDP, přičemž na investice vynaložila $10,52 \%,{ }^{4}$ což je třetí nejhorší výsledek v NATO, daleko za 2 \% HDP př́slibem z Walesu, nebo za obecným $20 \%$ doporučením NATO a Evropské obranné agentury (European Defence Agency - EDA) pro investiční výdaje. $^{5}$ Situace je o to horší, že za rok 2016 Ministerstvo obrany nevyčerpalo 4,1 mld. korun, které mohly být vynaloženy na nákup vojenského materiálu nebo služeb. ${ }^{6}$ Česká republika tak do obrany investuje nejen zlomek prostředků, ale není schopna tento zlomek ani zcela vyčerpat. To jasně ukazuje na strukturální problémy, se kterými se Česká republika a její Ministerstvo obrany potýká.

Politická diskuse nad dlouhodobou perspektivou rozvoje Společné bezpečnostní a obranné politiky (Common Security and Defence Policy - CSDP), jejím institucionálním a zdrojovým rámcem včetně role a míry zapojení České republiky je důležitá. $V$ kontextu odklonu Trumpovy administrativy od Evropy a oslabující role USA jako hlavního garanta evropské bezpečnosti v rámci NATO, je tato diskuse pro Českou republiku snad ještě závažnější. Efektivní obrana je základem bezpečnosti státu a předpokladem pro všechny jeho ostatní ekonomické, sociální a kulturní aktivity. Vzhledem ke svému postavení a historické zkušenosti nebude Česká republika o zajištění své bezpečnosti nikdy rozhodovat sama. Vždy tak bude činit v závislosti na rozhodování silnějších států, velmocí, at' v evropském nebo globálním formátu. Z toho vyplývá nutnost se aktivně podílet na formování „nové“ CSDP. Nicméně aby Česká republika byla schopná tuto roli hrát, definovat své pri-

4 Viz Návrh závěrečného účtu státního rozpočtu České Republiky za rok 2016, kapitola 307 - Ministerstvo obrany, Praha 2017. Dostupné z http://www.mocr.army.cz/images/id_5001_6000/5146/SZU_2016_ FINAL.pdf.

5 Viz Wales Summit Declaration, Brusel, 5. záŕi 2014. Dostupné z http://www.nato.int/cps/en/natohq/ official_texts_112964.htm?selectedLocale=en; 2010 Defence Data. Brussels: European Defence Agency, 2016, s. 2. ISBN 978-92-95075-28-3.

6 Viz Návrh závěrečného účtu státního rozpočtu České Republiky za rok 2016, ref. 4, s. 11. 
ority a následně je prosazovat, musí být nejprve vnitřně připravena, což v praxi znamená, vyřešit strukturální problémy, které ji dosud v hraní aktivnější role bránily. Níže je několik doporučení v hlavních podpůrných oblastech budování vojenských schopností, jenž mimochodem byly historicky hlavní osou práce EDA, a které by pro Českou republiku mohly být v tomto procesu vodítkem.

\section{ROZVOJ VOJENSKÝCH SCHOPNOSTÍ (CAPABILITIES)}

Česká republika by měla definovat, které z požadovaných schopností AČR bude rozvíjet autonomně bez přispění ostatních států (sovereignty principle) a které bude řešit ve spolupráci s ostatními státy at regionálně7 nebo v rámci NATO, EU (shared sovereignty). $V$ rámci druhé možnosti pak rozdělit ty, které bude rozvíjet na základě vzájemné dohody s ostatními státy, avšak bez vytvoření konkrétního mezinárodního mechanismu pro jejich nasazení (sharing principle), např. ve formě dohody o zajištění logistické podpory pro operační nasazení vybraných typů bojové techniky v zahraničních operacích. Dále pak ty schopnosti, které bude rozvíjet na základě mezinárodní dohody v podobě vytvoření nebo účasti v mezinárodní organizaci nebo struktuře, na kterou jsou delegovány národně vyvíjené nebo pořízené schopnosti (poling principle). Podobně například funguje Evropská letecká dopravní flotila (European Air Transport Fleet - EATF). Konečně pak na ty schopnosti, které budou budovány ve spolupráci s ostatními státy formou rozdělení úkolů a rolí za současného vzdání se, nebo naopak vytvoření nové, oblasti specializace jedinečné v rámci skupiny spolupracujících států (interdependence principle), např. specializace $v$ oblasti obrany proti chemickým, biologickým, radiologických a nukleárním (Chemical, Biological, Radiological and Nuclear - CBRN) látkám. V rámci tohoto kroku, který by mohl být zapracován do revidované verze Koncepce výstavby Armády České Republiky (AČR) či přiští Bílé knihy o obraně, tak Česká republika bude mít mnohem lepší představu, které z požadovaných schopností si ponechá v rámci své výlučné pravomoci, které bude možné využívat společně, a v jakých bude Česká republika a ostatní státy vzájemně závislé s cílem tyto schopnosti uchovat, neduplikovat jejich rozvoj a náklady s tím spojené, a dosáhnout synergie, například v rámci realizace EDAP Capability Window.

\section{VYZBROJOVÁNÍ (ARMAMENTS)}

Česká republika by měla přehodnotit současné akviziční postupy a flexibilně používat celou škálu existujících akvizičních možností s ohledem na zvolený způsob rozvoje vojenských schopností (například v případě sovereignty principle - viz výše - využívat článek

7 Viz KOLÍN, Vilém. Obrana ČR na rozcestí: Quo vadis? Obrana a strategie. 2011, roč. 11, č. 2, s. 138-139. ISSN 1214-6463. Dostupné z http://www.obranaastrategie.cz/cs/aktualni-cislo-2-2011/volna-tribuna/ obrana-ceske-republiky-na-rozcesti-quo-vadis.html\#.WSa4euSwdaQ. 
346 Smlouvy o fungování EU (SFEU), ${ }^{8}$ který v prípadě ochrany závažných bezpečnostních zájmů umožňuje zadat zakázku naprímo bez výběrového řízení) tak, jak to rámcově popisuje národní Strategie vyzbrojování a podpory rozvoje obranného průmyslu. ${ }^{9} \mathrm{~V}$ praxi se jedná o metodické rozpracování existující škály možností pořízení a o vytvoření interní směrnice, která by usnadnila výběr vhodného mechanismu pořízení v návaznosti na druh pořizovaného vojenského materiálu nebo služby. ${ }^{10} \mathrm{~V}$ principu jde o to stanovit a s předstihem několika let informovat ostatní státy a průmyslové subjekty, co Česká republika bude pořizovat jako již hotový produkt či službu (off-the-shelf), a kde se bude podílet na vývoji a výrobě nové generace obranných technologií v rámci kooperativních programů. ${ }^{11}$ Navzdory tomu, že kooperativní programy jsou páteří budování obranných schopností (napríklad letoun páté generace Lockheed Martin F-35 Lightning II, letoun čtvrté generace Eurofighter Typhoon, nebo transportní letoun Airbus A400M Atlas), obranného výzkumu i průmyslu, Česká republika se kooperativních programů neúčastní ani je aktivně nevyhledává. Prototypy, které mj. Evropská komise hodlá v rámci EDAP, finančně podporovat však budou primárně pocházet z kooperativních programů, možná napríiklad z rodícího se francouzsko-italsko-německého programu European MALE (Medium Altitude Long Endurance Remotely Piloted Aircraft System) RPAS. Česká republika by tak měla identifikovat, napřiklad v kontextu implementace Strategie vyzbrojování a podpory rozvoje obranného průmyslu, oblasti, ve kterých by byla ochotna se kooperativních programů účastnit a současně informovat ostatní státy o plánovaných pořizení off-the-shelf s cílem propojit budoucí národní investice $s$ investicemi ostatních států a z toho vyplývajícími možnostmi mezinárodní spolupráce. Česká republika by v této souvislosti měla co možná nejvíce využivat mezinárodních zkušeností v podobě tzv. nejlepší praxe (best practices), které jsou ve formě doporučení dostupné v rámci mezinárodních organizací včetně NATO a EDA. Otevření spolupráce s Evropskou organizací pro spolupráci ve vyzbrojování (L'organisme conjoint de coopération en matière d'armement OCCAR), hlavní mezivládní organizací odpovědnou za realizaci evropských kooperativních programů a do budoucna možného integrátora kooperativních iniciativ Evropské komise $v$ rámci EDAP a EDA, je pak další přiležitostí pro zapojení se do mezinárodní spolupráce, která může vyústit $v$ účast programu v rámci PESCO. Rozšířením akviziční škály

8 Viz Treaty of Lisbon Amending the Treaty of the European Union and the Treaty Establishing the European Community. Official Journal of the European Union, C 306, 17. prosince 2007.

9 Viz Strategie vyzbrojování a podpory rozvoje obranného průmyslu České republiky do roku 2025, Praha 2016. Dostupné z http://www.acr.army.cz/assets/technika-a-vyzbroj/modernizace/strategievyzbrojovani-do-2025.pdf.

10 Viz KOLÍN, Vilém. Proč Česká republika potřebuje strategii obranné průmyslové základny? Obrana a strategie. 2012, roč. 12, č. 1, s. 68-71. ISSN 1802-7199. Dostupné z http://www.obranaastrategie. cz/cs/archiv/rocnik-2012/1-2012/volna-tribuna/proc-ceska-republika-potrebuje-strategii-obranneprumyslove-zakladny.html\#.WSa31uSwdaQ.

11 V případě pořizení off-the-shelf se jedná o možnosti pořízení již „,volně dostupného“ vojenského materiálu nebo služeb na národní úrovni v rámci otevřeného výběrové řizení, nebo výběrového rrizení přeneseného na mezinárodní organizaci (např. v rámci Agentury NATO pro podporu a pořizení, NATO Support and Procurement Agency - NSPA), EDA, pořizení v rámci dohody vláda-vláda, nebo v rámci článku 346 SFEU. Pořizení off-the-shelf může mít formu i společného pořizení více státy. U kooperativního programu se jedná o pořizení nového, dosud nevyvinutého, obranného systému nové generace. 
a identifikací budoucích nákupů, včetně jejich navázání na způsob pořízení, získá Česká republika jasnou představu o tom, co nakoupí, a jak, a zda tak učiní sama či ve spolupráci s ostatními státy nebo organizacemi. Bude tak pro ní snazší definovat oblasti investičního zájmu na národní i evropské úrovni (ve vztahu k EDAP Capability Window) a současně umožní průmyslovým subjektům se na plánované akvizice připravit a formovat národní a mezinárodní konsorcia.

Jako doplňkový prostředek by Česká republika měla vytvořit systém vzdělávání programových manažerů zapojených do pořízení vojenského materiálu. Tito manažeři často realizují stamilionové nebo miliardové zakázky, a proto by mělo být v zájmu České republiky, aby se jim dostalo adekvátního vzdělání v problematice projektového řízení včetně řízení mezinárodních projektů, a souvisejícího právního, institucionálního a mezinárodního prostředí. $V$ této souvislosti by bylo možné uvažovat i o certifikaci procesu pořízení vojenského materiálu v souladu se standardem ISO $9001 .^{12}$

\section{OBRANNÝ VÝZKUM (RESEARCH \& TECHNOLOGY)}

Česká republika by měla přehodnotit své výzkumné a vývojové priority, jednak v návaznosti na rozvoj obranných schopností včetně potenciální účasti v kooperativních programech (viz výše), jež vždy zahrnují výzkumnou a vývojovou fázi (včetně prototypů), a jednak v návaznosti na schopnosti svých center obranného výzkumu tak, aby je mohla provázat s oblastmi a prioritami stanovenými pro př́ští rámcový výzkumný program EU. Obranný výzkum je páteří technologické převahy na bojišti, ale i motorem inovací obranného sektoru. $V$ rámci přelivu do ostatních oblastí (spin-offs) je pak důležitým inovačním zdrojem pro ekonomiku jako celek. Navzdory zdánlivé převaze inovačního potenciálu civilního sektoru, obranný výzkum byl a zůstává v pozadí většiny moderních technologiii. ${ }^{13}$ Bruselský žargon jako PA (Preparatory Action for Defence Research - Přípravná akce pro obranný výzkum), CDP (Capability Development Plan - Plán rozvoje schopností), OSRA (Overarching Strategic Research Agenda - Zastřešující strategická výzkumná agenda), nebo KSA (Key Strategic Activities - Klíčové strategické aktivity), v sobě skrývají jednak nové prríležitosti spolupráce $v$ obranném výzkumu (PA), jednak budoucí priority $v$ oblasti rozvoje schopností, výzkumu a vývoje (CDP, OSRA, KSA). Tyto priority budou definovány $v$ rámci mezivládního př́stupu uvnitř EDA dle nově přijatého politického rámce

12 Viz KOLÍN, Vilém. Hospodárný, efektivní a udržitelný rozvoj vojenských schopností ČR: Zbožné prání nebo politická nutnost? Obrana a strategie. 2010, roč. 10, č. 2, s. 124. ISSN 1214-6463. Dostupné z http:// www.obranaastrategie.cz/cs/aktualni-cislo-2-2010/volna-tribuna/hospodarny-efektivni-audrzitelny-rozvoj-vojenskych-schopnosti-cr.html\#.WSa1O-SwdaQ.

13 Cestování letadlem, satelitní komunikace, mobilní telefony, počítače, internet má vše svůj základ v obranném výzkumu. Například technologie použité pro řadu letadel Airbus A350 XWB pocházejí z $80 \%$ z obranné výzkumu. 
(Long Term Revue - LTR), ${ }^{14}$ přičemž budou později sloužit jako vodítko pro financování souvisejících projektů a programů v rámci EDAP. Česká republika by tak měla aktivně nominovat a finančně a organizačně podporovat účast vědeckých a průmyslových osobností a subjektů na relevantních fórech, kde budou priority definovány a související projekty vznikat, např́iklad na pravidelných jednáních dvanácti EDA CapTechs (Capability Technology Areas - Oblasti schopností a technologií), nebo na právě se tvoříím poradním fóru pro PA, které bude podporovat Evropskou komisi při sestavovaní ročních programů pro výzkum v rámci $\mathrm{PA}$, která je prologem $\mathrm{k}$ vytvoření nové, historicky bezprecedentní kapitoly pro financování obranného výzkumu, jenž bude patrně součástí príštího rámcového programu po skončení běžícího Horizon 2020. Konečně by Česká republika měla přehodnotit odpovědnost za obranný výzkum a vývoj, kdy nikoliv Ministerstvo obrany, ale Ministerstvo školství, mládeže a tělovýchovy financuje a ř́dí tyto aktivity. ${ }^{15}$ $\checkmark$ kontextu důležitosti této oblasti pro budování vojenských schopností je tato skutečnost nejen anachronismem, ale empiricky i jednou z hlavních překážek aktivnější účasti České republiky v mezinárodních projektech výzkumu a vývoje i kooperativních programů. Účast na programech $v$ rámci EDAP je jen těžko představitelná bez rozhodující role Ministerstva obrany $v$ této oblasti.

S cílem usnadnit mezinárodní spolupráci a zjednodušit zapojení domácích subjektů do mezinárodních výzkumných projektů a programů by Česká republika měla vytvořit informační systém, který by umožnil výměnu informací mezi Ministerstvem obrany (př́padně dalšími ministerstvy a relevantními orgány státní správy) a obranným prủmyslem (př́padně s dalšími průmyslovými segmenty a relevantními subjekty jako jsou vysoké školy, univerzity a organizace zabývající se výzkumem a vývojem). Tento systém by mohl být založen na ne/formálních konzultacích a webovém portálu, který by sloužil k vzájemné informovanosti v otázkách společného zájmu. Webový portál by měl obsahovat aktuální seznam národních a mezinárodních aktivit, kterých se české subjekty mohou zúčastnit, nebo ve kterých již participují, včetně podmínek účasti a kontaktních osob. ${ }^{16}$

\section{OBRANNÝ PRŮMYSL A TRH (DEFENCE INDUSTRY \& MARKET)}

Česká republika by měla aktivně podporovat zapojení svého obranného průmyslu do národních a mezinárodních projektů a programů, a to jak u kooperativních programů,

14 Viz Outcome of EDA Ministerial Steering Board, Brusel, 18. května 2017. Dostupné z https://www. eda.europa.eu/info-hub/press-centre/latest-news/2017/05/18/outcome-of-eda-ministerialsteering-board.

15 Viz Zákon č. 130/2002 Sb. o podpoře výzkumu, experimentálního vývoje a inovací. Dostupné z https:// portal.gov.cz/app/zakony/zakon.jsp?page=0\&nr=130 2F2002\&rpp=15\#seznam.

Viz KOLín, Vilém, ref. 13, s. 130. 
samostatných výzkumných projektů, nebo u pořízení off-the-shelf. ${ }^{17}$ Česká republika má na svém území několik významných průmyslových klastrů v oblasti letectví, obrněných vozidel, malých a lehkých zbraní, vojenského průzkumu a radarových systémů. ${ }^{18}$ Současně disponuje několika jedinečnými (niche) technologiemi v oblasti CBRN, vojenského výcviku a simulátorů, informačních technologií a služeb, nebo speciálních materiálů a laserů. České podniky, které v současnosti působí v obranném sektoru, převážně žijí z exportu na méně technologicky náročné trhy mimo Evropskou unii. Schopnost penetrovat tyto trhy se však může postupně snižovat, nebot' řada současných odběratelů českých firem buduje vlastní průmyslové kapacity (často z offsetů od velkých evropských firem), které v budoucnu mohou saturovat domácí poptávku a navíc se stát konkurentem českým i ostatním výrobcům. Technologický náskok a převaha je proto pro domácí i evropské výrobce nutností. Bez masivní podpory výzkumu a vývoje český obranný průmysl nebude schopen udržet své produkty na mimoevropských trzích ani vstoupit na trhy Evropské unie, kde jiné než špičkové technologie v silné konkurenci neobstojí. Současné produkty evropského obranného průmyslu, včetně českého, dnes těží z investic do výzkumu a vývoje alokovaných před dvaceti a více lety. Pokud české podniky, s nutnou podporou státu skrze akvizice a investice do výzkumu a vývoje a s tím související účastí v mezinárodních programech, nebudou aktivní a inovativní, zůstanou technologicky i kapacitně na periferii, a Česká republika nebude mít hráče k zapojení se do mezinárodních programů.

Zájmem České republiky by proto mělo být zmapovat národní obranné průmyslové a technologické kapacity, podporovat je a dále rozvíjet, jednak jejich provázáním ne-li prímo zapojením do plánovaných akvizic (at́ už v rámci pořízení off-the-shelf, kooperativních programů nebo projektů výzkumu a vývoje), jednak podporou jejich účasti v mezinárodních projektech a programech, a aktivní proexportní politikou. Současně je třeba stimulovat domácí firmy $\mathrm{k}$ převzetí role systémového integrátora, který by byl v rámci komplexnějších zakázek, nebo účasti v mezinárodních konsorciích, schopen okolo sebe soustředit jako subdodavatele malé a střední podniky, výzkumné a vědecké instituce. Roli systémového integrátora v rámci mezinárodních projektů (např́klad v rámci PA nebo později v rámci příštího rámcového programu) by měly především hrát státní podniky a výzkumné ústavy, nebot' na ně může stát přímo působit a současně je v rámci existujících státních struktur podpořit doma i v zahraničí. V neposlední řadě je třeba přehodnotit prístup $\mathrm{k}$ prostredkům ze Strukturálních fondů EU a využívat je i pro obranný průmysl, což může vyvolat potřebu revize Národní výzkumné a inovační strategie pro inteligentní

17 Obranný průmysl je kličovou komponentou výstavby obranných schopností a nositelem jedinečného know-how, technologií, a kompetencí, bez kterých se žádný národní nebo evropský program neobejde. Prvotní impuls k zahájení projektu, programu, nebo pořízení off-the-shelf však nepřichází z průmyslu, ale od státu, který stanoví požadavky, právní a finanční rámec, a u mezinárodních projektů a programů i účastnický podíl (Cost-share/Work-share Arrangement).

$18 \mathrm{~K}$ historickému kontextu a specifik obranného průmyslu států střední a východní Evropy viz KOLíN, Vilém. Towards Balanced Defence Industry in Europe: Main Specificities of Central and Eastern European Defence Industries. IRIS Notes. 5. března 2015, s. 1-15. Dostupné z http://www.iris-france.org/wpcontent/uploads/2015/03/IRIS-Note-March-2015-V-Kolin1.pdf. 
specializaci ČR s cílem učinit ji přívětivou i vưči obrannému sektoru (defence friendly). ${ }^{19}$ S implementací EDAP totiž začíná být možné využívat prostředků strukturálních fondů v obranném sektoru, avšak jen pokud to zapadá do Národní výzkumné a inovační strategie. Podobně se začíná měnit přistup k evropským finančním nástrojům, například $\mathrm{k}$ podpoře financování malých a středních podniků a jejich aktivit v obranném sektoru $v$ rámci evropského programu COSME (Competitiveness of Enterprises and Small and Medium-sized Enterprises - SMEs), nebo v rámci podpory projektů v oblasti dovedností a znalostí ERASMUS+ a Evropského sociálního fondu (European Social Fund - ESF), kde EDA již vytváří mechanismus podpory k účasti v takových projektech. Česká republika by touto cestou mohla získat další prostředky na podporu svého obranného průmyslu, jeho strategického rozvoje a inovativního potenciálu. Aktivní průmyslovou podporou, podloženou dobrou znalostí domácího průmyslu, založenou na zmapování kapacit, schopností a kompetencí obranného i civilního sektoru, např́klad v rámci implementace Strategie vyzbrojování a podpory rozvoje obranného průmyslu, Česká republika bude nejen lépe připravena identifikovat možné dodavatele vojenského materiálu a služeb pro národní akvizice, ale, a to především, schopna lépe definovat a formovat svoji národní průmyslovou účast $v$ mezinárodních projektech a programech, nebot ty jsou právě v hledáčku EDAP Capability Window. Bez reálné průmyslové účasti Česká republika nebude schopná $v$ těchto projektech a programech působit ani do nich vstoupit.

\section{ZÁVĚR}

Evropská unie stojí na prahu nové éry, kdy jedno z dlouhodobých politických tabu je prolomeno v důsledku vnějších a vnitřních tlaků. Budování společné obrany pod taktovkou Evropské komise nebude vždy snadné, levné ani spravedlivé. Lze oprávněně očekávat, že v rámci probíhající diskuze s členskými státy se současné návrhy, mechanismy, odpovědnosti i finanční rámce dále promění. Jedno však zůstane nezměněno, a sice ambice Evropské unie učinit v budoucnu obranu jednu ze svých komunitárních politik. Česká republika není v jednoduché pozici, obrana byla po desetiletí „enfant terrible“ vládního establishmentu a spoléhání se na členství v NATO levných řešením zajištění národní bezpečnosti. Navzdory četným a úspěšným misím AČR v zahraničí, strukturální problémy zůstávají a brání České republice být plně zapojitelná (insertable) do evropských aktivit v oblasti budování obranných schopností, vyzbrojování, výzkumu a vývoje, obranném průmyslu a trhu, podobně jako to $v$ jiné podobě dokázali čeští vojáci v zahraničních misích. Přes jisté dílčí úspěchy a nadšenecké aktivity pár zainteresovaných se při pohledu z Bruselu Česká republika nejeví v obraně jako chytrý zákazník (Smart Customer), který v evropském formátu ví, co chce, přemýšlí jakým způsobem to získat, a činí tak s vědomím dosažení nejlepší hodnoty za vynaložené peníze (best value for money). Politické

19 Viz Národní výzkumná a inovační strategie pro inteligentní specializaci ČR (Národní RIS3 strategie). Dostupné z http://www.msmt.cz/strukturalni-fondy/ris3-strategie-cr. 
deklarace mohou ukázat směr, ale bez vytvoření podpůrných politik, nástrojů, procesů, a mechanismů, které by tyto deklarace realizovaly, nic nezmění. Evropská unie má v tomto směru také co dohánět: přehnaná regulace trhu s obranným materiálem, vysoké administrativní nároky na účast v evropských projektech nebo na spolufinancování z evropských fondů, nedostatečná znalost specifik obranného sektoru atd. Navzdory tomu se evropská obrana pomalu stává realitou, a pro Českou republiku je to šance, možná poslední, jak tohoto procesu využít pro svoji vnitřní transformaci a strukturální změny v oblasti obrany. Pokud chce Česká republika obstát v řešení množících se krizí, které dříve nebo později mohou přejít ve válečný konflikt s evropskou účastí, další alternativy se již nenabízí. Samozřejmě úspěch není garantován, na evropské ani na české straně. Ale pokud se o to Evropská unie ani Česká republika nepokusí, riskujeme, že další generace budou žít možná s větším traumatem, než pro nás je to mnichovské.

Autor: $\quad$ PhDr. Vilém Kolín, Ph.D., MGS. Narozen 1974. Od prosince 2016 pracuje jako Senior Defence Industry Policy Officer se zaměřením na Industry Relations and Support/SMEs v Ředitelství pro průmysl a trh Evropské obranné agentury (EDA) v Bruselu. Zde také od zárí 2010 pracoval jako Senior Defence Industry Data Officer. Titul Ph.D. získal v oboru Mezinárodní vztahy na Fakultě sociálních věd Univerzity Karlovy v Praze v roce 2010. Zaměruje se na problematiku Společné obranné a bezpečnostní politiky EU, obranného průmyslu a trhu, realizace mezinárodních programů a dále pak na problematiku legality a legitimity použití ozbrojené sily v mezinárodních vztazích.

Jak citovat: KOLÍN, Vilém. Česká republika a „nová“ Společná bezpečností a obranná politika EU: Čas zásadních rozhodnutí. Vojenské rozhledy. 2017, 26 (3), 68-77. ISSN 1210-3292 (print), 2336-2995 (on-line). Available at: www.vojenskerozhledy.cz 


\section{Společné financování NATO - včera, dnes a zítra}

\section{NATO Common Funding - Yesterday, Today and Tomorrow}

\section{Josef Múčka}

Abstrakt: Společné financování NATO již 65 let slouží k financování společných potřeb Aliance a významně tak přispívá k posilování její akceschopnosti, soudržnosti a solidarity. Zejména v období posledních několika let byla schválena a ve většině prípadů i implementována řada reformních opatření s cílem účelnějšího, hospodárnějšího, efektivnějšího a transparentnějšího vynakládání společných zdrojů Aliance a zavedení moderního finančního managementu. Společné financování tak je živým a funkčním systémem. Prostor pro další zlepšení však samozřejmě nadále existuje. Ambicí príspěvku je popsat úlohu společného financování NATO, jeho základní parametry a nástroje, jak se postupně vyvíjelo, a aktuální a budoucí výzvy.

Abstract: The NATO common funding has already been used to finance common needs of the Alliance for 65 years and has contributed substantially to its readiness, cohesion and solidarity. A number of reform measures have been approved, and in most cases already implemented, over the period of last several years with the aim of more effective, economical, efficient a transparent use of NATO common funds and the introduction of modern financial management practices. NATO common funding is therefore a live and well-functioning system. Nevertheless, there is still a room for further improvements.

The aim of this article is to describe the role of NATO common funding, its basic parameters and tools, its development in the past, and current and future challenges.

Klíčová slova: NATO; financování; plánování zdrojů; reformy.

Key words: NATO; funding; resource planning; reforms. 


\section{ÚVOD}

Společné financování NATO v rámci Aliance hraje již 65 let velice významnou a vskutku nezastupitelnou roli. Cílem tohoto článku je popsat úlohu a nástroje společného financování NATO, jak se postupně vyvíjelo, jaké jsou aktuální výzvy a co lze očekávat od budoucnosti. Volně tak navazuje na článek ${ }^{1}$ Ing. Josefa Procházky, Ph.D. z roku 2012.

\section{ÚLOHA A ZÁKLADNÍ PARAMETRY SPOLEČNÉHO FINANCOVÁNÍ NATO}

Společné financování NATO slouží k financování společných potřeb Aliance, mezi něž patří zejména provoz ústředí NATO, jeho velitelské struktury či společně provozovaných schopností2, společné potřeby $v$ rámci aliančních operací a misí, či rozvoj schopností $v$ rámci Programu bezpečnostních investic NATO (NATO Security Investment Programme - NSIP).

Objem výdajů v rámci společného financování činí v posledních letech cca $2 \mathrm{mld}$. EUR, což představuje cca 0,3 \% souhrnných obranných výdajů členských zemí NATO. Jde tedy o relativně nízkou částku - její význam pro Alianci je však zásadní, protože společné financování významně přispívá k posilování její akceschopnosti, soudržnosti a solidarity a k naplňování jejích cílů.

V rámci společného financování jsou financovány pouze aktivity, které přesahují př́mou odpovědnost jednotlivých členských zemí a jdou nad rámec toho, co může být po spojencích rozumně očekáváno, že budou financovat z národních zdrojů. Tuto skutečnost vyjadřuje i základní princip společného financování NATO, tzv. princip „Over and Above“. 3 Ten je u operací a misí NATO ještě posílen tzv. principem „costs lie where they fall“, tj. že náklady nese ten, komu vzniknou. Jednotliví spojenci jsou tak jasně zodpovědní za financování aktivit spojených s přípravou a použitím svých ozbrojených sil a i v rámci operací jsou financovány pouze společné potřeby, které nelze přiřadit konkrétnímu spojenci (např. provoz či výstavba velitelství, apod.).

Společné financování NATO tvoří tři pilíře:

- Vojenský rozpočet NATO, sloužící k financování provozních výdajů prvků a programů velitelské struktury NATO (NATO Command Structure - NCS), provozu společně provozovaných schopností (zejména NAEW\&C, AGS), společných potřeb v rámci

1 PROCHÁZKA, J. Společné financování NATO jako nástroj posilující soudržnost a akceschopnost této mezinárodní organizace, Vojenské rozhledy, 2012, roč. 21 (53), č. 4, s. 25-34, ISSN 1210-3292. Dostupné z www.vojenskerozhledy.cz

2 Zejména vzdušný systém včasné výstrahy a řizení NATO (NATO Airborne Early Warning \& Control NAEW\&C) a systém vzdušného sledování pozemních cílů (Alliance Ground Surveillance - AGS)

3 "Common funding will focus on the provision of requirements which are over and above those which could reasonably be expected to be made available from national resources". Zdroj: NATO, A layman's guide to NATO (common) funding. SG(2006)0047, 19. 1. 2006 
operací a misí NATO a penzí bývalých civilních zaměstnanců vojenských velitelství. Prakticky tak v rámci Vojenského rozpočtu NATO existuje cca 35 dílčích rozpočtů;

- Program bezpečnostních investic NATO (NSIP), v jehož rámci jsou pořizovány společné alianční schopnosti, jako jsou komunikační a informační systémy (např. výpočetní technika, telefonní a datové linky, strategické spojení v rámci aliančních operací a misí, aj.), infrastruktura vojenských velitelství, páteřní letiště, námořní základny, sklady, dopravní potrubí pohonných hmot apod.;

- Civilní rozpočet NATO, sloužící k financování Mezinárodního štábu NATO (International Staff - IS), jeho programů4 a penzí bývalých pracovníků.

Výši výdajů v rámci společného financování NATO popisuje následující tabulka (výdaje v mil. EUR):

\begin{tabular}{|lrrrrrr|}
\hline mil. EUR & $\mathbf{2 0 1 1}$ & $\mathbf{2 0 1 2}$ & $\mathbf{2 0 1 3}$ & $\mathbf{2 0 1 4}$ & $\mathbf{2 0 1 5}$ & $\mathbf{2 0 1 6}$ \\
Vojenský rozpočet & 1383,5 & 1393,6 & 1579,4 & 1510,2 & 1160,3 & 1141,4 \\
NSIP & 686,3 & 555,1 & 525,9 & 538,4 & 595,4 & 508,5 \\
Civilní rozpočet & 210,0 & 211,3 & 206,1 & 212,4 & 216,8 & 220,2 \\
\hline Celkem & 2279,8 & 2160,0 & 2311,4 & 2261,0 & 1972,5 & 1870,1 \\
\hline
\end{tabular}

Tabulka č. 1: Vývoj výdajů společného financování NATO 5

Výdaje společného financování NATO charakterizuje měnící se celková výše vojenského rozpočtu, zapřičiněná v minulých letech zejména změnami v oblasti výdajů na operace a mise NATO, poměrně stabilní výše výdajů u civilního rozpočtu, a nízká míra implementace u programu NSIP (kde byly stropy financování v minulých letech na úrovni cca 700 mil. EUR, reálné čerpání však bylo průměrně pouze na úrovni cca 80 \%).

Společné financování NATO je jakousi „společnou peněženkou“, do níž spojenci přispívají na základě dohodnutých podílů - klíčů sdílení nákladů, které jsou každé dva roky přepočítávány dle výkonnosti ekonomiky jednotlivých spojenců.

V následující tabulce je uveden aktuální přehled klíčů sdílení nákladů spojenců na období let 2016 - 2017 pro vojenský rozpočet, civilní rozpočet i NSIP pro rozpočty financované všemi spojenci: 6

4 napríklad tzv. „Science for Peace and Security Programme“, který je nástrojem pro spolupráci s partnery v oblasti vědeckého výzkumu, inovací a výměny znalostí

5 Resource Policy and Planning Board, 2014 RPPB Annual Report-Executive Summary. AC/335-N(2015)0056, 24. 7. 2015. Dostupné na www.nato.int/cps/cn/natohq/topics_111582.htm?selectedLocale=enResource Policy and Planning Board, RPPB 2015 Annual Report - Executive Summary. AC/335-N(2016)0067, 3. 8. 2016. Dostupné na www.nato.int/cps/cn/natohq/topics_111582.htm?selectedLocale =en

6 Pozn.: některé rozpočty jsou financovány menším počtem spojenců - např. z důvodu, že někteří spojenci přispívají svými kapacitami (např. NAEW\&C, AGS). Podíly jednotlivých spojenců jsou pak alikvotně upraveny. 


\begin{tabular}{|l|l|}
\hline Albánie & 0,0837 \\
\hline Belgie & 1,9331 \\
\hline Bulharsko & 0,3262 \\
\hline Kanada & 6,6074 \\
\hline Chorvatsko & 0,2893 \\
\hline Česká republika & 0,9386 \\
\hline Dánsko & 1,1826 \\
\hline Estonsko & 0,1084 \\
\hline Francie & 10,6310 \\
\hline Německo & 14,6461 \\
\hline Řecko & 1,0871 \\
\hline Mad'arsko & 0,6909 \\
\hline Island & 0,0519 \\
\hline Itálie & 8,4085 \\
\hline Lotyšsko & 0,1490 \\
\hline
\end{tabular}

\begin{tabular}{|l|l|}
\hline Litva & 0,2280 \\
\hline Lucembursko & 0,1399 \\
\hline Černá Hora & 0,0270 \\
\hline Nizozemsko & 3,1796 \\
\hline Norsko & 1,6988 \\
\hline Polsko & 2,7110 \\
\hline Portugalsko & 0,9795 \\
\hline Rumunsko & 1,0723 \\
\hline Slovensko & 0,4680 \\
\hline Slovinsko & 0,2121 \\
\hline Španělsko & 5,7788 \\
\hline Turecko & 4,3866 \\
\hline Velká Británie & 9,8459 \\
\hline USA & 22,1387 \\
\hline
\end{tabular}

Tabulka č. 2: Přehled klíčů sdílení nákladů spojenců na období 2016-2017,

Obecně platí, že příspěvky do vojenského rozpočtu a NSIP hradí ministerstva obrany členských zemí, příspěvky do civilního rozpočtu ministerstva zahraničních věcí.

Řízení společného financování NATO a jeho nástroje

Řízení společného financování NATO vychází z jeho charakteru: příspěvky hradí členské země Aliance, které tak společně rozhodují o tom, jak budou prostředky využity a kontrolují implementaci. I v této oblasti je přitom při rozhodování uplatňován princip nezbytnosti dosažení konsensu všech spojenců.

Zásadní roli hraje Severoatlantická rada (North Atlantic Council - NAC), která zejména schvaluje př́slušné politiky společného financování (tj. co je ze společného financování možné hradit), klíče sdílení nákladů, stropy financování a plány zdrojů, civilní a vojenský rozpočet a hodnocení skutečné realizace společného financování. Velice důležitou roli hraje i Vojenský výbor NATO (Military Committee - MC), který schvaluje vojenské požadavky a priority, z nichž vychází požadavky v oblasti společného financování.

$K$ naplnění své zásadní role zř́dil NAC strukturu zdrojových výborů. Koncepční roli hraje Výbor pro politiku a plánování zdrojů NATO (Resource Policy and Planning Board RPPB), který je přímo podřízen NAC. $\mathrm{K}$ hlavním úkolům RPPB patří příprava zdrojových doporučení k rozhodnutí NAC, integrace práce zdrojových výborů a směřování jejich činnosti, definování pravidel pro využívání společných finančních prostředků Aliance, rozhodování o způsobilosti (eligibility) k financování předložených požadavků ze společného

7 NATO, Cost Share Arrangements for Civil Budget, Military Budget and NATO Security Investment Programme Valid from Accession of Montenegro until 31 December 2017. Přehled dostupný na www. nato.int/cps/en/natohq/topics_67655.htm 
financování, posuzování finanční dostupnosti (affordability) aktivit Aliance a střednědobé plánování zdrojů.

RPPB jsou podřizeny implementační výbory: Rozpočtový výbor (Budget Committee - BC) pro oblast vojenského rozpočtu a civilního rozpočtu ( $v$ praxi existují dva oddělené formáty tohoto výboru - pro vojenský rozpočet a pro civilní rozpočet) a Investiční výbor (Investment Committee - IC) pro oblast řízení implementace NSIP.

Podporu pro činnost zdrojových výborů poskytuje Úřad NATO pro zdroje (NATO Office of Resources - IS/NOR), který je začleněn ve struktuře IS ústředí NATO. Pracovníci tohoto úřadu posuzují podklady předložené vojenskými orgány a dalšími prvky NATO a připravují podkladové dokumenty pro jednání zdrojových výborů.

Společné financování v oblasti vojenského rozpočtu a NSIP důsledně vychází z definovaných vojenských požadavků. Klíčovou roli tak hrají i již zmíněný MC, dále Mezinárodní vojenský štáb (International Military Staff - IMS) a velitelství v rámci NCS, zejména strategická velitelství (pro operace: Allied Command Operations - ACO a transformaci: Allied Command Transformation - ACT).

Vlastní implementaci programu NSIP zajištují tzv. „hostitelské země“, jimiž mohou být jak konkrétní spojenci, na jejichž území jsou př́slušné projekty NSIP realizovány, tak agentury NATO či vojenská velitelství. Agentury NATO (řízené svými řídícími radami, v nichž jsou zastoupeni všichni spojenci) přitom nyní implementují podstatnou část projektů. Zejména přitom jde o Komunikační a informační agenturu NATO (NATO Communications and Information Agency - NCIA) a Agenturu NATO pro podporu a pořizování (NATO Support and Procurement Agency - NSPA).

$\checkmark$ praxi tak existuje poměrně složitá a někdy ne zcela přehledná řídící struktura, jejíž zlepšení je jednou z aktuálních výzev a zároveň úkolem ze summitu NATO ve Varšavě8.

Pravidla společného financování jsou obecně vymezena řadou základních dokumentů ${ }^{9}$, schválených NAC. Přijímání rozhodnutí o konkrétních požadavcích se odvijí od těchto pravidel (a to často $s$ přihlédnutím $k$ rozhodnutím učiněným v minulosti). Pro některé oblasti existují samostatná detailnější pravidla financování (např. pro operace a mise NATO či oblast vzdělávání, výcviku a cvičení, k podpoře od hostitelských zemí apod.).

Zásadní význam v řízení společného financování má proces plánování zdrojů. RPPB připravuje Střednědobý plán zdrojů (Medium Term Resource Plan - MTRP) pro oblast vojenského rozpočtu a NSIP. ${ }^{10}$ MTRP je nástrojem plánování zdrojů na strategické úrovni řizení. $K$ přípravě MTRP je na začátku plánovacího procesu vydávána plánovací směrnice. MTRP vychází z požadavků strategických velitelů a tzv. „Consolidated NMA Impact Statements (CNIS)“, v nichž vojenské orgány Aliance (NATO Military Authorities - NMA) seřazují požadavky dle priorit a popisují rizika vyplývající ze zdrojových omezení. Validita požadavků je posuzována BC a IC. Po projednání v RPPB je MTRP předkládán ke schválení NAC.

8 Warsaw Summit Communiqué, čl. 137. Dostupné na www.nato.int/cps/en/natohq/official_texts.htm

9 napríklad C-M(93)38(Final) „Renewal of the Infrastructure Programme“, SRB-N(96)33(Revised) „Eligibility for NATO Common Funding" či PO(2013)0071 "Report by the RPPB on the Review of NATO Common Funding"

10 V oblasti civilního rozpočtu je připravován Střednědobý finanční plán (Medium Term Financial Plan) na 5 let, který po projednání BC (ve formátu pro civilní rozpočet) a odsouhlasení RPPB schvaluje NAC 
Na základě MTRP připravuje RPPB finanční stropy na následující rok, které schvaluje NAC. Diskuse ke stropům financování jsou zpravidla velice složité a citlivé. Vliv mají rozdílné přistupy spojenců ke společnému financování, spojené s odlišnostmi v jejich očekáváních, ale např. i rozdílná národní legislativa spojenců, která limituje flexibilitu některých z nich v oblasti alokace prostředků.

Na základě stropů financování připravují prvky NCS jednotlivé dílčí vojenské rozpočty, které projednává $B C$. $B C$ následně připravuje návrh Vojenského rozpočtu NATO, který po projednání v RPPB schvaluje NAC. BC je zodpovědný i za průběžné sledování, vyhodnocování a úpravy schváleného rozpočtu ( $v$ rámci schválených stropů).

Odlišná situace je v NSIP, nebot' na rozdíl od Vojenského rozpočtu NATO jde o investiční program. V rámci NSIP jsou nejprve zpracovávány tzv. programy rozvoje schopností (Capability Package - CP). Ty vycházejí z vojenských požadavků, definovaných na počátku procesu strategickými velitelstvími ( $A C O$ a $A C T$, vedoucí roli hraje $A C O)$. Na jejich základě připravují strategická velitelství návrh CP (vedoucí role $\mathrm{ACT}$ ) s identifikací rozdílu mezi požadovanými a stávajícími schopnostmi a projekty navrženými k odstranění nedostatků. Návrhy CP předkládají ACO a ACT společně do ústředí NATO. Následně IS a IMS zpracovávají společnou zprávu (Joint Staff Screening Report - JSSR) s posouzením obsahu CP a doporučeními pro MC a RPPB. MC posuzuje tuto zprávu a CP z hlediska vojenských požadavků a priorit a RPPB z hlediska způsobilosti ke společnému financování a dostupnosti zdrojů. Po odsouhlasení CP v MC a RPPB je CP postoupeno NAC ke schválení. Jednotlivé projekty NSIP pak posuzuje a autorizuje IC, který sleduje i stav implementace a schvaluje závěrečné inspekce projektů. V závislosti na vývoji stavu implementace jednotlivých CP připravuje IC podklady do MTRP za oblast NSIP. Specifikem financování NSIP je, že v něm neexistuje centrální účet: financování probíhá tak, že IS/NOR na základě definovaných potřeb připraví výzvy $\mathrm{k}$ zaplacení příspěvků a jednotliví spojenci si na základě těchto výzev finanční prostředky zasílají mezi sebou.

Činnost $v$ rámci společného financování NATO $v$ daném roce je vyhodnocena ve Výroční zprávě RPPB, která je předkládána ke schválení NAC.

\section{OHLÉDNUTí DO HISTORIE}

Aliance začala se společným financováním poměrně krátce po svém vzniku. Se vznikem společných struktur a započetím spolupráce na výstavbě obranné infrastruktury vznikly k jejich financování v roce 1951 i Vojenský rozpočet NATO, Civilní rozpočet NATO a Infrastrukturní program. Zároveň byl zřízen i Rozpočtový výbor (Budget Committee) pro civilní rozpočet, Výbor pro vojenský rozpočet (Military Budget Committee) a Infrastrukturní výbor (Infrastructure Committee) pro Infrastrukturní program. Ten byl v té době - a dále ještě následujících cca 40 let - zaměřen téměř výhradně na infrastrukturu v členských zemích, a členěn byl na „plátky“ (slices) po jednotlivých obdobích (projekty tak nebyly seřazeny dle schopností). Výše uvedené výbory byly prímo podřizeny NAC a byly ve své činnosti zcela samostatné.

Společné financování v obranné oblasti bylo tenkrát zcela unikátní věcí - jediným známým případem $v$ historii do té doby bylo společné financování ve starověkém Řecku 
(tzv. Délský spolek), kdy v 5. století př. n. I. udržovalo několik městských států společnou pokladnu na potřeby obrany proti Persii. ${ }^{11}$

Zásadním impulsem pro změny ve společném financování byl konec studené války, kdy se Aliance a tím i společné financování musely přizpưsobit změněným bezpečnostním podmínkám. Snahy o revizi a modernizaci procedur, větší integraci a lepší řízení společného financování vyvrcholily v roce 1993, kdy dosavadní poměrně statický infrastrukturní program nahradil Program bezpečnostních investic NATO - NSIP s novými procedurami, přičemž základním nástrojem v programování společných investic (a to již nejen infrastruktury) začaly být již zmíněné CP. Zároveň byl v roce 1993 vytvořen i tzv. Senior Resource Board (předchůdce RPPB), zodpovědný za řizení společného financování ve vojenské oblasti (tj. NSIP a Vojenský rozpočet).

Dalším důležitým bodem byl rok 2005, kdy byl schválen nový spravedlivější způsob výpočtu klíčủ sdílení nákladů spojenců v rámci společného financování NATO, založený na výkonnosti ekonomiky. Původní klíče sdílení nákladů byly stanoveny historicky (u zakládajících členů v roce 1951 - hlavním kritériem tehdy byla „schopnost platit“) a byly tak mezi nimi výrazné nepoměry. Významnou roli v rámci přípravy této nové metodiky sehrála ČR, kdy tehdejší velvyslanec ČR při NATO Karel Kovanda jako doyen diplomatického sboru Aliance vedl diskuse vedoucí k jejímu prosazení. O citlivosti této změny vypovídá i skutečnost, že přechodové období trvalo 10 let a k plnému přechodu na novou metodiku došlo až u klíču sdílení nákladů pro roky 2016 - 2017.

Významným milníkem ve snaze o zlepšení managementu společného financování a integrace bylo i vytvoření IS/NOR (2007), který podporuje činnost všech zdrojových výborů.

Následujícím zásadním impulzem pro změny byla kritická situace v NSIP v roce 2009 a globální finanční krize. Zejména narůstající požadavky operace ISAF vedly v roce 2009 v NSIP k původně neočekávanému výraznému nárůstu výdajů (na 777 mil. EUR), které významně překročily tehdejší strop financování (653,3 mil. EUR). Situaci dále ztížila globální finanční krize (začala v r. 2008), která následně vedla k redukci obranných rozpočtů většiny spojenců (včetně ČR). Ze vzniku a složitosti snah o řešení tohoto problému bylo zjevné, že existující procesy je nezbytné změnit tak, aby byla zajištěna lepší kontrola, větší transparentnost, zdroje byly vynakládány efektivněji a hospodárněji a byla opět vytvořena rovnováha mezi požadavky a dostupnými zdroji.

Reforma řízení zdrojů začala jako součást celkové reformy NATO s cílem adaptovat Alianci na současné a budoucí výzvy, zvýšit efektivitu včetně lepšího fungování struktur a dosáhnout úspor (motto: udělat více s méně prostředky - „doing more with less“). Na summitu NATO v Lisabonu ${ }^{\mathbf{1 2}}$ v roce 2010 schválily hlavy států a vlád kromě reformy řizení zdrojů i reformu NCS, aliančních agentur a ústředí NATO. Změny v oblasti společného financování následně proběhly zejména v oblastech plánování, prioritizace, informační podpory, většího důrazu na poskytování klíčových schopností, posílení transparentnosti, zodpovědnosti a auditu, zlepšení finančního managementu a managementu NSIP (včetně lepšího dohledu nad tímto programem a větší interakce s hostitelskými zeměmi).

11 Zdroj: NATO Office of Resources, NATO Security Investment Programme Manual, 2011 
Proběhla i revize pravidel společného financování včetně schválení nových pravidel pro financování operací, pro oblast vzdělávání, výcviku a cvičení a pro poskytování podpory hostitelskými zeměmi. $V$ roce 2010 byly zdrojové výbory reorganizovány na současnou strukturu.

Vzhledem ke komplexnímu charakteru změn a potřebě delšího časového období na jejich implementaci je zatím brzo na celkové zhodnocení jejich přínosu. Již nyní je ale možné konstatovat, že změny obecně šly správným směrem a přispívají ke zlepšení procesu společného financování NATO. Zároveň je však bylo nutné doplnit sadou dalších opatření, které jsou popsány v následující části tohoto článku. Podařilo se dosáhnout i poměrně velkých úspor ( $v$ rozsahu cca 50 mil. EUR ročně), které nicméně nedosahují původně předpokládané výše. Navýšily se naopak jednorázové transformační náklady, přičemž hlavní příčinou tohoto stavu je komplikovaná transformace NCIA.

Původní reformní zadání z Lisabonu proto summit ve Walesu ${ }^{13}$ (2014) doplnil o další úkoly v oblasti společného financování, a to připravit doporučení ke zvýšení transparentnosti a finanční zodpovědnosti, doporučení ke zlepšení procesu pořizování společně financovaných schopností a revizi procesu plánování zdrojů. RPPB tato doporučení připravil v roce 2015 v součinnosti s vojenskými orgány Aliance a NAC je schválil. V současnosti probíhá rozpracování schválených opatření a jejich implementace.

\section{DNEŠNÍ VÝZVY}

Společné financování NATO již desítky let slouží k financování společných potřeb Aliance a významně přispívá k posilování její akceschopnosti, soudržnosti a solidarity. $V$ předchozím období byla schválena a ve většině případů i implementována řada reformních opatření s cílem účelnějšího, hospodárnějšího, efektivnějšího a transparentnějšího vynakládání společných zdrojů Aliance a aplikace moderního finančního managementu. Společné financování tak nyní bezesporu je živým a funkčním systémem. Prostor pro další zlepšení však samozřejmě nadále existuje.

Velkou aktuální výzvou v oblasti bezpečnosti a obrany je měnící se bezpečností prostředí, které má a bude mít vliv na Alianci a jednotlivé spojence. NATO se vrací ke kořenům, se zaměřením na společnou obranu, posílení společných schopností, společný výcvik apod., což samožrejmě má a bude mít vliv i na činnosti a programy financované $v$ rámci společného financování NATO. Relativně klidné období, kdy jsme se - v návaznosti na redukce obranných výdajů - snažili „dělat více s méně“, tak již skončilo a s rostoucími požadavky nyní začíná růst i objem prostředků vynakládaných v rámci společného financování.

Snaha dělat více s méně přitom (nepřekvapivě) nenaplnila původní očekávání: nižší úroveň vstupů $\mathrm{k}$ vyšším výstupům nevedla a úsporná opatření např. v programu NSIP, realizovaná v době výše zmíněné globální finanční krize, jsou jednou z příčin nízké úrov-

13 Wales Summit Declaration, čl. 111 a 112, dostupné na www.nato.int/cps/en/natohq/official_texts.htm 
ně čerpání v tomto programu, se souvisejícími dopady na rozvoj společných schopností Aliance.

Rozpracování a plná implementace některých opatření je vzhledem k jejich složitosti (dané v některých případech i mezinárodním prostředím) „během na dlouhou trat'“, což je i prrípad opatření připravených v návaznosti na úkoly ze summitu ve Walesu.

Zejména jde o zlepšení procesu pořizování společně financovaných schopností. Zde nyní k hlavním problémům, které mají negativní vliv na rozvoj schopností, patří délka procesu, kdy čas od zahájení přípravy $\mathrm{CP}$ po dokončení implementace trvá průměrně cca 16 let, nízká míra implementace NSIP ( $v$ několika posledních letech bylo reálné čerpání NSIP výrazně pod schválenými stropy financování), složitost řídících struktur, kdy struktura zodpovědnosti je poměrně složitá a nepřehledná a jasně nastavená není ani zodpovědnost za celý proces.

Nedostatky jsou jak v kvalitě a délce přípravy, posuzování a projednávání investičních projektů, tak v rámci hodnocení a kontroly jejich implementace a ukončování. Na tyto problémy a nedostatky upozornila v roce 2015 ve své zprávě o auditu NSIP14 i Mezinárodní rada auditorů NATO (International Board of Auditors for NATO - IBAN). RPPB proto v součinnosti s vojenskými orgány navrhl řadu opatření, k nimž patři lepší definování struktury zodpovědnosti v rámci celého procesu, implementace transparentních a realistických plánů rozvoje schopností, zlepšení společných zpráv IS a IMS v rámci posuzování identifikovaných požadavků, zlepšení zpráv o skutečné implementaci schopností, revize procesů a struktur ACT, lepší provázání s procesem obranného plánování NATO (NDPP) apod. Vzhledem $\mathrm{k}$ širším aspektům řízení procesu pořizování společně financovaných schopností nyní na zlepšení celkového nastavení rízení pracuje Výbor zástupců stálých představitelů při NATO (Deputies Committee, DPRC). U většiny dalších opatření již implementace probíhá.

Na konci května 2016 pak IBAN dokončil výkonnostní audit procesu přípravy $\mathrm{CP}^{15}$. $K$ hlavním zjištěním opět patřila délka procesu, nedostatky v procesu přípravy $C P$, a to např. v oblasti personálu, informační podpory a nastavení řízení. Neefektivní je dle IBAN i proces definování požadavků na schopnosti, kdy navíc př́prava CP obecně nevychází z požadavků NDPP. Tato zjištění jsou pravdivá a nejsou žádným překvapením: $k$ jejich odstranění většinou směřují již schválená opatření z roku 2015. RPPB následně připravil další opatření tak, aby byly odstraněny i zbývající problémy.

Aktuální výzvou je i implementace nového procesu plánování zdrojů. Na základě úkolu ze summitu ve Walesu připravil RPPB doporučení ke zlepšení v této oblasti, která NAC schválil v červnu $2015^{16}$. RPPB usiloval o vyřešení problémů dosavadního procesu (zejména zaměření v zásadě pouze na stanovení finančních stropů na následující rok, s tím související nedostatečný důraz na pořizování schopností, délka procesu, jeho načasová-

14 IBAN, Special Report to Council on the Need to Reform NATO Security Investment Programme Governance. C-M(2015)0043 z 8. 6. 2015, dostupné na www.nato.int/cps/en/natohq/topics_111783.htm

15

IBAN, Performance audit report to Council on the need to improve NATO's Capability Package proces. IBA-A(2016)51 z 24. 5. 2016, dostupné na www.nato.int/cps/en/natohq/topics_111783.htm

16 Resource Policy and Planning Board, Reviewing the Common Funded Resource Planning. PO(2015)0356, 19. 6. 2015 
ní, nedostatečné propojení s NDPP, apod.). MTRP byl navíc pravidelně schvalován pozdě ( $v$ minulých letech vždy až po začátku rozpočtového procesu), čímž byla devalvována jeho hodnota pro řízení. Cílem nového nastavení plánování je větší orientace procesu a jeho výstupu - MTRP - na plánování s důrazem na plánování schopností a provázání s NDPP. Schváleny byly i změny harmonogramu procesu MTRP a jeho nastavení a větší zaměření hodnotícího procesu na implementaci schopností. Zároveň došlo $\mathrm{k}$ rozdělení na dvě etapy - stanovení stropů financování na následující rok a plánování na dalších 5 let. Vzhledem k rozdílným názorům spojenců na výše stropů financování a zpožd'ování práce NMA na CNIS však dochází ke zpožd'ování schvalování jednotlivých plánovacích dokumentů a tím i implementace nového nastavení plánování.

Související sada dalších reformních úkolů je uvedena i v Plánu zdrojů 2016, připraveném v rámci přechodu na nový proces plánování zdrojů. Jde např. o úkoly v oblasti implementace nového nastavení procesu plánování zdrojů, vyjasnění zodpovědnosti, zavedení systému řízení výkonosti, zvýšení flexibility vedoucích pracovníků (s delegací pravomocí a jasně vymezenou zodpovědností) apod.

Summit NATO ve Varšavě ${ }^{17}$ (červenec 2016) v oblasti společného financování uložil i úkol zlepšit prioritizaci k zajištění lepšího provázání politických a vojenských priorit $s$ požadavky $v$ oblasti zdrojů a potvrdil úkol zlepšit celkové nastavení rízení procesu pořizování společně financovaných schopností.

Další aktuální výzvou je nárůst požadavků vojenského rozpočtu NATO, zejména provozních výdajů prvků a programů velitelské struktury NATO, a to v souvislosti s financováním podpory systému velení a řizení vzdušných sil Aliance (Air Command and Control System - ACCS), výcviku a v oblasti provozu komunikačních a informačních systémů. Nárůsty nákladů jsou často způsobeny přechodem na nové technologie (se zvyšujícími se provozními náklady), zároveň však v řadě případů souvisí i s přechodem na zákaznické financování NCIA. Zákaznické financování se zatím nejeví jako velký úspěch - mj. i vzhledem $\mathrm{k}$ ne zcela jasné a komplikované struktuře rízení, pravomocí a zodpovědnosti.

Zároveň rostou i výdaje na provoz AGS a na podporu implementace Akčního plánu pripravenosti (Readiness Action Plan - RAP), schváleného na summitu NATO ve Walesu. Implementace RAP bude mít - spolu s realizací dalších nových CP - dopady zejména na NSIP - v budoucnu tak Ize očekávat i vyšší čerpání v tomto programu (oproti současné nízké míre implementace).

Tyto nárůsty požadavků nejsou žádným překvapením (oproti stavu v roce 2009) a jsou finančním vyjádřením již učiněných rozhodnutí spojenců. Jde přitom většinou o prioritní požadavky. Diskuse spojenců k (rostoucím) stropům a plánovaným úrovním financování jsou však i nadále komplikované: po létech úspor již ve vojenském rozpočtu NATO nezbylo mnoho aktivit s nízkou prioritou, které by bylo možné zrušit bez negativních dopadů na činnost prvků NCS. A zároveň po redukcích obranných výdajů rady spojenců $\checkmark$ minulých letech jsou obranné rozpočty některých z nich stále velmi napjaté, což má vliv na jejich ochotu navyšovat výdaje společného financování.

Spojenci si však uvědomují nezbytnost adekvátního financování NCS, což je důležitý předpoklad pro nalezení řešení tohoto problému a vytvoření rovnováhy mezi požadavky

17 Warsaw Summit Communiqué, čl. 137, dostupné na www.nato.int/cps/en/natohq/official_texts.htm 
a finančními možnostmi. To se ukázalo i v roce 2016, kdy se po složitých jednáních podařilo v ř́jnu nalézt kompromisní řešení stropů financování pro rok 2017, akceptovatelné pro všechny spojence. Tento rok pak byl MTRP na roky 2018-2022 schválen NAC v červenci.

\section{VAZBA NA ČR A JEJÍ POZICE}

ČR si uvědomuje zásadní význam společného financování pro Alianci. Dlouhodobě podporujeme reformu NATO včetně reformního úsilí směřujícího $k$ lepšímu řízení a využívání společných finančních prostředků NATO tak, aby společné financování ještě efektivněji poskytovalo potřebné společné schopnosti Aliance a přispívalo tak k posilování její akceschopnosti a soudržnosti. $\mathrm{V}$ této souvislosti usilujeme zejména o zlepšení procesu plánování a pořizování společně financovaných schopností, přičemž dlouhodobě požadujeme větší orientaci MTRP na plánování s důrazem na plánování schopností a provázání s NDPP. Aktivně jsme se tak účastnili i diskusí směřujících k novému nastavení plánování a na prípravě nových opatření v rámci pořizování společně financovaných schopností.

ČR do společného financování NATO (Vojenský rozpočet, NSIP, Civilní rozpočet) aktuálně přispívá cca 0,5-0,6 mld. Kč ročně. Část prostředkủ se ČR přitom vrací - zejména formou financování projektů NSIP v ČR (v letech 1999-2016 v celkovém objemu cca 3,7 mld. Kč - např. na letištní infrastrukturu, páteřní radiolokátory, implementaci ACCS ad.). České podnikatelské subjekty mají navíc možnost participovat na zakázkách hrazených ze společného financování vyhlašovaných hostitelskými zeměmi (agentury NATO, členské země, velitelství).

\section{PŘEDPOKLÁDANÝ BUDOUCÍ VÝVOJ V RÁMCI SPOLEČNÉHO FINANCOVÁNÍ}

Jak řekl slavný dánský fyzik Niels Bohr: „Předpovědi jsou složité, zvláště když se týkají budoucnosti“. $V$ př́padě společného financování je nicméně možné zejména blízkou budoucnost předpovědět s rozumnou mírou přesnosti.

Pokračovat budou práce na procesním nastavení, a to zejména v oblasti zlepšení procesu pořizování společně financovaných schopností. Připravena bude nová struktura řízení s jasnějším nastavením zodpovědnosti a pravomocí, zkrácena celková délka procesu (od identifikace požadavků až po dokončení projektů), zlepšena informační a personální podpora, lépe bude nastavena vazba na NDPP, a to mj. i prostřednictvím tzv. kolektivních cílů. Implementovány budou moderní způsoby řízení, včetně systému řízení (a měření) výkonnosti. Plně implementováno bude nové nastavení procesu plánování zdrojů, a dále zlepšena prioritizace požadavků. Další nová racionalizační opatření budou v budoucnu bezpochyby následovat a nastavení procesu společného financování NATO bude nadále průběžně přizpůsobováno novým podmínkám.

S narůstajícími potřebami bude nadále nezbytné balancovat požadavky s dostupnými zdroji: lepší nástroje, včetně lepšího plánování a prioritizace, poskytnou kvalitnější infor- 
mační podporu pro rozhodování. Spojenci tak budou mít pro kvalifikované rozhodnutí ještě lepší vstupy než nyní a zároveň by měli být dostatečně přesvědčeni i o efektivnosti a hospodárnosti vynakládání prostředků. I nadále však zřejmě budou pokračovat složité a citlivé diskuse stropů financování, protože konečné rozhodnutí - učiněné konsensem - je nakonec v rukou spojenců. Na těch pak záleží, jakou částku jsou a budou ochotni vynaložit pro potřeby společného financování NATO.

\section{ZÁVĚR}

Společné financování NATO je živým a funkčním systémem, který významně přispívá k posilování akceschopnosti, soudržnosti a solidarity Aliance. Během své dosavadní historie prošlo poměrně velkým vývojem a dosud bylo vždy schopno reagovat na všechny výzvy a změny.

Zejména v období posledních několika let byla schválena a ve většině případů i implementována řada reformních opatření s cílem účelnějšího, hospodárnějšího a efektivnějšího vynakládání společných zdrojů Aliance a zavedení moderního finančního managementu. Prostor pro další zlepšení však nadále existuje a další racionalizační opatření budou v budoucnu bezpochyby následovat. Nastavení procesu společného financování NATO tak bude nadále průběžně přizpůsobováno novým podmínkám a spojenci tak mají a budou mít stále lepší vstupy pro kvalifikovaná rozhodnutí.

\section{Seznam použitých zkratek:}

\begin{tabular}{|l|l|l|}
\hline ACO & Allied Command Operations & strategické velitelství NATO pro operace \\
\hline ACT & Allied Command Transformation & strategické velitelství NATO pro transformaci \\
\hline BC & Budget Committee & Rozpočtový výbor \\
\hline CP & Capability Package & program rozvoje schopností \\
\hline DPRC & Deputies Committee & $\begin{array}{l}\text { Výbor zástupců stálých predstavitelů při } \\
\text { NATO }\end{array}$ \\
\hline IBAN & International Board of Auditors for NATO & Mezinárodní rada auditorů NATO \\
\hline IC & Investment Committee & Investiční výbor \\
\hline IS & International Staff & Mezinárodní štáb NATO \\
\hline IS/NOR & NATO Office of Resources & Úřad NATO pro zdroje \\
\hline MC & Military Committee & Vojenský výbor NATO \\
\hline MTRP & Medium Term Resource Plan & střednědobý plán zdrojů \\
\hline NAC & North Atlantic Council & Severoatlantická rada \\
\hline NCIA & NATO Communications and Information & Komunikační a informační agentura NATO \\
\hline Agency & NATO Command Structure & velitelská struktura NATO \\
\hline NDPP & NATO Defence Planning Process & proces obranného plánování NATO \\
\hline NMA & NATO Military Authorities & vojenské orgány Aliance \\
\hline NSIP & NATO Security Investment Programme & Program bezpečnostních investic NATO \\
\hline NSPA & NATO Support and Procurement Agency & Agentura NATO pro podporu a pořizování \\
\hline RPPB & Resource Policy and Planning Board & Výbor pro politiku a plánování zdrojů NATO \\
\hline
\end{tabular}


Autor: Ing. Josef Múčka, nar. 1970, absolvent VVŠ PV Vyškov (1993), obor ekonomika armády - finance. Od roku 1993 pracuje na MO (na různých pozicích nejdřive ve finančni oblasti a následně v oblasti obranného plánování). $V$ letech 2006-2009 byl obranným poradcem na Stálé delegaci ČR při NATO, kdy od roku 2007 působil na Úřadu NATO pro zdroje (na oddělení pro plánování a politiku zdrojů). V letech 2009-2014 byl reditelem odboru strategického rozvoje SOPS MO. Od srpna 2014 do konce července 2017 byl obranným poradcem na Stálé delegaci ČR při NATO a zástupcem ČR ve Výboru pro politiku a plánování zdrojů NATO. Od 1. 8. 2017 nastoupil opět na odbor strategického rozvoje SOPS MO. V letech 1996, 1997 a 1998 absolvoval studijní pobyty v zahraničí (USA, Švédsko a SRN) v oblastech řízení zdrojů a obranného plánování.

Jak citovat: MÚČKA, Josef. Společné financování NATO - včera, dnes a zítra. Vojenské rozhledy. 2017, 26 (3), 78-90. ISSN 1210-3292 (print), 2336-2995 (on-line). Available at: www.vojenskerozhledy.cz 


\section{K polemice Luboše Dobrovského s Janem Eichlerem \\ Commentary on Luboš Dobrovský's Controversy with Jan Eichler}

\section{Michael Romancov}

Abstrakt: Text je reakcí na polemiku Luboše Dobrovského a Jana Eichlera na stránkách Vojenských rozhledů, která byla věnována limitům a (ne)vhodnosti neorealistického prístupu k interpretaci současné vojensko-bezpečnostní situace v postsovětské oblasti z českého pohledu. Text se snaží ukázat, že neorealistický přistup, jenž se soustředí na tzv. materiální atributy moci, nevyhnutelně bere v úvahu i historický a hodnotový kontext, jenž však výsledky zkoumání problematizuje. Proto je představen př́stup Teda Hopfa, který je na zkoumání mezinárodních vtahů prostřednictvím kombinace materiálních atributů a idejí založen.

Abstract: Text is reaction to disputation between Lubos Dobrovsky and Jan Eichler in Vojenské rozhledy magazine, which was dealing with limits and inappropriate of neoliberal approach to analysis of military-security situation in post-soviet space from Czech point of view. Text tries to point out, that neorealistic approach, which focuses on material source of power, inevitably deals with ideas as well. Therefore, Ted Hopf's approach, whcih combines attention to material power and ideas, is introduced.

Klíčová slova: Teorie MV; funkce teorie MV; neorealismus; zdravý rozum; rusko-americké soupeření.

Keywords: Theory of IR; Function of Theory of IR; Neorealism; Common Sense; Russo-American Rivalry. 


\section{ÚVOD}

Ve Vojenských rozhledech 2/2016 byla pod názvem „Polemika s neorealistickými teoriemi mezinárodních vztahů, o něž se opírá článek Jana Eichlera Černomořská dimenze války na Ukrajině ve VR 2016/1" zveřejněna polemika Luboše Dobrovského, na kterou Jan Eichler v čísle 2/2017 odpověděl textem „Neorealismus a současné americko-ruské vojenské soupeření v postsovětském prostoru“. Oba protagonisté svá stanoviska prezentovali věcně, srozumitelně a zdá se, že dále ponechali na čtenářích, aby o předložených argumentech přemýšleli. Mám za to, že vzhledem k rychle se měnící mezinárodně-politické i vojensko-bezpečnostní situaci by se této polemiky mohlo využít jako základu pro širší diskusi (nejen) nad tématy, které Luboš Dobrovský a Jan Eichler již otevřeli.

\section{JÁDRO POLEMIKY}

Pokud jsem správně pochopil hlavní námitku Luboše Dobrovského, tak mu na prvním textu Jana Eichlera vadilo, že se autor, když prezentoval kritiku rozšíření NATO na východ/ do Černomoří, dostatečně nevěnoval hodnotovému rozměru této „expanze na pozvání". Uvedl k tomu: „Takto Janem Eichlerem pojatý výklad expanze, at' již soft, smart, nebo hard, je velice nepřesvědčivý a ve skutečnosti zatemňuje samu podstatu rozdílů mezi jednáním Západu, reprezentovaného v Evropě především Severoatlantickou aliancí, tedy obranným sdružením demokratických států, a Ruskem, reprezentovaným v oné době nepochybně nedemokratickým sovětským režimem... ${ }^{1}$ Jan Eichler „hozenou rukavici“ zdvihl a ve svém druhém textu se pokusil pohled amerických neorealistů na americko-ruské soupeření pojmout šířeji a komplexněji. Došel k závěru, že: „...dnešní Západ a zejména pak USA jsou $v$ jednoznačně nadřazeném postavení, nebot' mají obrovskou výhodu v obou směrech vyvažování... Naproti tomu Ruská federace je v jasně podřízeném postavení... Jedná pod silným tlakem, který často přerůstá až v pocit obklíčené pevnosti a následující sekuritizační pohyby. Její vyzbrojování má negativní charakter, jeho smyslem je dohánět náskok USA, jedná se o klasické napodobování.“. 2 V posledním odstavci pak Jan Eichler uvedl: „A zcela na konec se ještě vyjádřím k Dobrovského výtce, že neorealismus je „pohrdání vůlí občanů toho kterého státu rozhodovat o vlastním osudu bez obav.“ Ta mne inspiruje $k$ závěru, že $v$ dnešní Evropě jde a nějakou dobu ještě půjde o vyvažování mezi dvěma krajními podobami „pohrdání“. Tu první jasně vymezil můj kritik, druhou vymezuji já. Považuji za ni hrozbu pohrdání možnými vojenskými důsledky konfrontační politiky, které je typické zejména pro politické elity těch nových členských zemí, na je-

1 DOBROVSKÝ, L. Polemika s neorealistickými teoriemi mezinárodních vztahů, o něž se opírá článek Jana Eichlera Černomořská dimenze války na Ukrajině ve VR 2016/1. Vojenské rozhledy č. 2/2016. Roč. 25 (57), $144-147$.

2 EICHLER, J. Neorealismus a současné americko-ruské vojenské soupeření v postsovětském prostoru. Vojenské rozhledy č. 2/2017. Roč. 26 (58), 104. 
jichž území se budují nové vojenské základny NATO... Teprve následující měsíce či roky ukáží, které z těchto dvou pohrdání je méně špatné a nebezpečné, než to druhé... 3

Podrobný a pečlivý přenos argumentů vybraných amerických neorealistů do českého prostředí, který Jan Eichler v obou svých textech zpracoval, představuje cenný příspěvek do debaty, kterou česká bezpečnostní komunita vede, či by vést měla. Jsem přesvědčen, že jakkoli musíme v prvé řadě věnovat pozornost všem potenciálním soupeřům a protivníkům, je třeba pečlivě mapovat i vývoj a posuny v myšlení našich sousedů a spojenců. Kdybychom nevěnovali pozornost tomu, jak a proč o světě kolem nás, a zejména pak o prostoru, který je nám geograficky blízký, smýšlí náš nejdůležitější spojenec, ohrozíme jen sami sebe. Na druhou stranu bychom však nikdy neměli ztratit ze zretele právě onen historický a hodnotový kontext, po němž naléhavě volá Luboš Dobrovský. Jan Eichler uvedl: „L. Dobrovský tedy má pravdu, že já, podobně jako jiní neorealisté, věnuji charakteru současného režimu v Rusku a osobě jeho prezidenta velmi malou pozornost. Plně uznávám, že jak režim, tak i jeho nejvyšší představitel se z euroatlantického úhlu pohledu jeví ve velmi nepříznivém světle. Ale i tak se budu snažit držet čistě věcné stránky, kterou je neorealistický pohled na současné americko-ruské soupeření. “4

\section{KDYŽ POLEMIKA INSPIRUJE ...}

Výše uvedené mě inspirovalo k zamyšlení dvojího druhu. Zaprvé je zde vlastní jádro polemiky obou aktérů, jímž je (ne)existence hodnotového rozměru neorealistického prístupu konkrétně, a jeho (ne)významu v teoriích mezinárodních vztahů obecně. Zadruhé pak otázka, nakolik je neorealistický přístup (ne)spolehlivý při snaze porozumět Rusku, respektive predikovat jeho možné kroky, vezmeme-li v úvahu šrámy, jenž tento přístup, ostatně stejně jako všechny ostatní, utrpěl, pokud šlo o neschopnost predikovat, respektive vůbec vzít v úvahu, rozpad SSSR.

Naprosto nezpochybňuji tvrzení Jana Eichlera, že neorealismus zůstává jednou z nejvlivnějších teorií MV a v oblasti zkoumání bezpečnosti a velmocenského soupeření přináší mimořádně cenné výsledky. Relativní nezávislost zahraničně-politického a vojensko-bezpečnostního chování států na jejich vnitřním uspořádání, anarchická struktura mezinárodního systému, stejnorodost jednotek a proměnlivá distribuce moci jsou natolik silně ověřeny praxí, že se s nimi špatně polemizuje. Ve hře je však několik podstatných a důležitých „ale“, kterým bychom se měli věnovat.

Pokud jde o normativní rozměr teorií mezinárodních vztahů, uvádí Encyklopedie MV: „Pohled na funkce teorií se liší v závislosti na filosoficko-vědní pozici, na jejímž základě je teorie budována. $V$ zásadě se lze setkat s teoriemi, které mají za úkol poznat, popsat a vysvětlit okolní realitu; přispívat k přehlednějšímu uspořádání informací o okolní realitě; přispívat

3 EICHLER, J. Neorealismus a současné americko-ruské vojenské soupeření v postsovětském prostoru. Vojenské rozhledy č. 2/2017. Roč. 26 (58), 105.

4 EICHLER, J. Neorealismus a současné americko-ruské vojenské soupeření v postsovětském prostoru. Vojenské rozhledy č. 2/2017. Roč. 26 (58), 90. 
k žádoucímu uspořádání okolní reality... Funkce teorie se liší i dle jejich vztahu k praktické aplikaci na společenské a mezinárodně-politické dění. Existuje velice významná část sociálních vědců a filosofů sociálních věd, kteří se domnívají, že přemýšlení o společnosti v sobě nezbytně zahrnuje normativní prvky“. ${ }^{5}$ Heslo normativní funkce teorie pak uvádí, že tato: „mưže být naplněna zejména dvěma způsoby. Zaprvé ideologickou kritikou současného poznání je možné otevřít cestu pro alternativní způsoby organizace lidského života, a tedy i mezinárodní politiky. Zadruhé teorie hledají odpovědi na otázky, jak by věci měly vypadat... Normativní teorie $v$ mezinárodních vztazích se potýkají se základním problémem, který vyplývá z toho, že „západní“ teorie dobrého života a dobře organizace politického společenství, která je vlastní politickým vědám, je obtižně přenositelná do prostřední mezinárodní politiky. “6 Podle stejného zdroje patři neorealismus mezi teorie, u nichž lze nalézt vysvětlující a instrumentální, ale později i normativní funkci.

Pokud za nejdůležitější nosný prvek neorealismu budeme považovat ideu rovnováhy moci a hledání ekvilibria, zjistíme, že v českém akademickém prostředí již diskuse nad touto otázkou probíhala. V textu „Koncepce rovnováhy moci ve 20. stoleti“ Jiří Šedivý uvedl: „Waltz dokonce tvrdí, že: „existuje-li vůbec zřetelně politická teorie mezinárodní politiky, je to teorie rovnováhy moci“. Přestože je přesvědčen o tom, že rovnováha moci je hlavním organizačním principem mezinárodní politiky nelze - jak sám varuje - od její teorie očekávat vysvětlení všech motivů chování jednotlivých států, podobně jako - řečeno Waltzovými slovy - „obecná teorie gravitace nevysvětlí zákruty dráhy padajícího $l i s t u$ "7. Vždy je [proto] nutné mít na paměti, že koncepce, jejich případné hodnocení a kritiky neexistuji ve vzduchoprázdnu. Jsou dílem konkrétních lidí, žijících v konkrétní historické situaci a ideové atmosféře." 8 Mám za to, že nemůže být sporu o tom, že američtí neorealisté svá pozorování vedou primárně ze Spojených států, používají americký/ západní vědecký diskurz a závěry, či případná doporučení, nakonec adresují americké odborné veřejnosti, či přímo příslušné americké administrativě. Jak (ne)přesné však jsou jejich závěry ohledně ruských pocitů a představ? Nakolik mohou fenomény materiální povahy, stojící v centru jejich pozornosti, jakými jsou např́klad změny v rozloze území, počtu obyvatel, stavu ekonomiky či vojenských sil spolehlivě odrážet něco tak nemateriálního, jako je, jak cituje Jan Eichler, v Rusku znovu sílící „fenomén obklíčené mocnosti“. ${ }^{9}$ $\mathrm{Na}$ tomto místě si nelze nepoložit otázku: existovalo v ruských dějinách, včetně jejich sovětské epochy, nějaké období, kdy pocit obklíčené mocnosti nebyl přítomen? Nejedná se nakonec o základní ideu, která dává smysl, pokud ne celým ruským dějinám, tak rozhodně existenci silného státu?

Jsem si zcela vědom, že neorealismus, respektive američtí autoři, které Jan Eichler citoval, něco takového primárně neřeší, řešit nemůže a řešit nechce. Pokud však vzpomenutí autoři používají formulace typu: „Pronikání USA a jejich spojenců dále na východ jistě

5 KRATOCHVÍL, P.; DRULÁK, P. Encyklopedie mezinárodních vztahů. Praha: Portál, 2009, 74.

6 KRATOCHVÍL, P.; DRULÁK, P. Encyklopedie mezinárodních vztahů. Praha: Portál, 2009, 75.

7 ŠEDIVÝ, J. Koncepce rovnováhy moci ve 20. století. Mezinárodní vztahy č. 2/1998. Vol. 33, 71.

8 ŠEDIVÝ, J. Koncepce rovnováhy moci ve 20. století. Mezinárodní vztahy č. 2/1998. Vol. 33, 78-79.

9 EICHLER, J. Neorealismus a současné americko-ruské vojenské soupeření v postsovětském prostoru. Vojenské rozhledy č. 2/2017. Roč. 26 (58), 101. 
nemá za cíl zvětšit území USA, ale naplňuje znaky toho, čemu se říká „prevence vzniku dominantního státu“. Právě proto vyvolává v Rusku silné obavy, že se vytváří struktura, která pro něj znamená bezpečnostní hrozbu. $V$ důsledku toho v Rusku znovu sílí fenomén obkličené mocnosti, který je vždy a všude velice nebezpečný a v Rusku má navíc hluboké historické kořeny. “10 je jasné, že se zdaleka neomezují pouze na aspekty materiální, ale berou v úvahu i historický, případně hodnotový, kontext.

Domnívám se, že pro pochopení tak specifického aktéra, jakým je Ruská federace, by bylo velmi vhodné použít teorii, která kombinuje materiální aspekty světa mezinárodních vztahů a ideje. $V$ tomto ohledu považuji za originální a potenciálně nosný přístup, který roku 2013 v článku Common-sense Constructivism and Hegemony in World Politics představil Ted Hopf.

Hopf uvádí, že vychází z práce Roberta Coxe, který již roku 1981 představil hegemonistickou teorii, která kombinovala atributy materiální distribuce moci, idejí a vlivu mezinárodních organizací ${ }^{11}$ Jejím jádrem byla představa, že hegemonie nevzniká pouze nátlakem, ale také díky schopnosti nabídnout k „odběru“ (subscription) sdílené a legitimizované ideje. ${ }^{12}$ Cox svou představu hegemonistické teorie staví na argumentech, vypůjčených od Gramsciho. Připomeňme, že Gramsci se mimo jiné věnoval tzv. hegemonii v diskurzu, když tvrdil, že buržoasie prostřednictvím svých intelektuálů ovládá společenský diskurz. Tato hegemonie jí umožňuje třídní zájem vykořist'ovatelů prohlásit za obecnou pravdu či univerzální normu, jež jí následně usnadňuje reprodukci vykořistovatelských vztahů. ${ }^{13}$

Hopf s Coxem souhlasí, ale domnívá se, že v oblasti mezinárodních vztahů hraje při budování hegemonistického řádu klíčovou roli, vedle atributů materiální povahy, i to, co je označováno termínem „zdravý rozum“ (common sense). Všeobecně je prijímáno, že se lidé nejčastěji a nejdůrazněji dovolávají tzv. zdravého rozumu tehdy, když chtějí prosadit své názory a mohou argumentovat pouze empirickými zkušenostmi. Mocnost, která usiluje o udržení, obnovu či nastolení hegemonie je nevyhnutelně a logicky aktivní i v oblasti kulturní, vzdělávací a informační výměny. Snaží se, případně je schopna svůj pohled na svět prosadit s takovou intenzitou, že její ideje začnou být většinovou populací brány jako zaručené a objektivní „pravdy“. Taková tvrzení pak většinová populace nevystavuje žádnému empirickému nebo normativnímu zkoumání či zpochybňování. Tyto pravdy se pak stávají součástí „zdravého rozumu“, který se stává hlavní „filozofickou výbavou nefilozofů, zcela nekriticky vstřebanou konceptualizací světa“. ${ }^{14}$

10 EICHLER, J. Neorealismus a současné americko-ruské vojenské soupeření v postsovětském prostoru. Vojenské rozhledy č. 2/2017. Roč. 26 (58), 101.

11 HOPF, T. Common-sense Constructivism and Hegemony in World Politics. International Organization. Vol. 67, No. 2 (Spring 2013), 317.

12 HOPF, T. Common-sense Constructivism and Hegemony in World Politics. International Organization. Vol. 67, No. 2 (Spring 2013), 320. 
Otázku, zda existuje, respektive jaký je vztah, mezi výše naznačeným zdravým rozumem a mezinárodním řádem Hopf řešil právě na př́kladu Ruska a jeho vztahu k Západu. Položil si čtyři základní otázky: Jaká je Ruská materiální pozice v kontextu západní hegemonie; jaký je „zdravý rozum“ ruských mas; jaký má ruská elita hegemonistický projekt a konečně jak do sebe poslední dvě kategorie diskurzivně zapadají. ${ }^{15}$ Nikterak překvapivě dospěl k závěru, že neoliberální diskurz, který ještě na počátku druhé dekády 21 . století ruské elity veřejně deklarovaly, byl v rozporu se „zdravým rozumem“ ruské společnosti, což podle jeho názoru naprosto koresponduje s místem, které Rusko zaujímá ve světě je semi-periferií světa, v němž dominuje Západ. ${ }^{16}$

Hopf si velmi dobře uvědomil, že ruský „zdravý rozum“ pracuje s kategoriemi, které se nerozporují, a proto je není třeba podrobovat zkoumání, či o nich pochybovat. Jsou to kategorie tak samozřejmé, že o nich ani není třeba mluvit. ${ }^{17}$ Hopf uvádí řadu př́kladů, na nichž přesvědčivě ilustruje v podstatě známé neúspěchy ruské politické tranzice a ekonomické transformace, a jejich prostřednictvím ukazuje na zvětšující se rozpor mezi přihlášením se k západnímu neoliberálnímu diskurzu, čímž byla reprodukována a posilována hegemonie Západu, a „zdravým rozumem“ ruských mas. Ukazuje, že materiální základna Ruska/ruského režimu, se vyvíjela ve všech základních měřitelných kategoriích negativně či spíše negativně (demografický vývoj, úroveň vědy a výzkumu, nerovnoměrný rozvoj hospodářské základny) samožrejmě se známými výjimkami, jimiž byly zásoby a těžba surovin (s dominantní pozicí ropy a plynu), výdaje na zbrojení a jaderné síly. Ne zcela přesvědčivým způsobem však ukazuje, a je otázkou, jak moc to $v$ době, kdy jeho text vznikal, již bylo vidět, že se ruské elity, které směrem do zahraničí i nadále reprodukovaly prejatý západní diskurz, směrem dovnitř úspěšně zmocnily „zdravého rozumu“.

Podobnou metodu, jakou zvolil Hopf, použil pro výklad politického chování Ruska i polský filozof a sociolog Pawel Rojek, ve své práci Rusko: prokletí impéria. Zdroje politického chování (česky vyšlo 2015). Rojek se rozhodl zabývat se především idejemi a nikoli politickou praxí. „Vyplývá to z fundamentálního předpokladu, že lidé jednají ne na základě toho, jak se věci mají, ale na základě toho, jak myslí, že se věci mají. ${ }^{18}$ Podobně jako před ním už napríklad Richard Pipes ${ }^{19}$, Martin Malia ${ }^{20}$ nebo Ryszard Kapuşciński21 tak činí prostřednictvím rozboru základní nosné ideje existence Ruska, kterou je idea Moskvy, coby třetího Říma. Tuto ideu přibližuje jako permanentní spor mezi ideou státu a národa, mezi izolacionismem a expanzionismem a mezi náboženskými a světskými základy

15 HOPF, T. Common-sense Constructivism and Hegemony in World Politics. International Organization. Vol. 67, No. 2 (Spring 2013), 324.

16 HOPF, T. Common-sense Constructivism and Hegemony in World Politics. International Organization. Vol. 67, No. 2 (Spring 2013), 348.

17 HOPF, T. Common-sense Constructivism and Hegemony in World Politics. International Organization. Vol. 67, No. 2 (Spring 2013), 324. 
státu. V dějinách Ruska máme co do činění se třemi interpretacemi ideje „třetího Říma“, nebot' v dějinách ruského národa se původní vznešená myšlenka náboženská, tedy idea vyvolenosti ruského národa, dostala do styku s politickou doktrínou odůvodňující vývoj impéria. „Nový Jeruzalém je náboženský a programově neusiluje o expanzi. Novy Konstantinopol je náboženský a o expanzi programově usiluje. Nový Řím je expanzionistický a náboženský základ chybí. Neexpanzionistická koncepce bez náboženského základu chybí, respektive její nositelé jsou tak marginální, že se ji zatím nikdy nepodařilo předložit jako konkurenceschopný projekt...."22

Vrat'me se nyní k tomu, co leží v centru pozornosti neorealistů, tedy k problémům změny $v$ distribuci moci a snaze po obnovení ekvilibria. Např́ílad Nicholas Spykman uvedl, že snaha po nalezení rovnováhy moci je $v$ anarchickém prostředí mezinárodních vztahů tím jediným, co se blíží ráádu, ale mocnosti neusilují o rovnováhu jako takovou, ale o rovnováhu, která je v jejich prospěch. Nikoli ekvilibrium, ale dostatečná převaha je jejich cílem. ${ }^{23}$ Nebo, jak ř́ká Mearsheimer: Velké mocnosti jsou jen zrrídka spokojeny se současným stavem věcí, namísto toho čelí permanentnímu pokušení o prosazení změn, které by jim přinesly prospěch. Téměř vždy projevují revizionistické tendence, a budou-li mít pocit, že je změna proveditelná za rozumnou cenu, nebudou se zdráhat použít sílu. ${ }^{24}$

S plným vědomím toho, že Jan Eichler nechal záměrně znít hlas amerických autorů, bych nyní, ve snaze podepř́t argument o nezbytnosti vzít v úvahu i hodnotový a historický kontext, chtěl nechat zaznít hlas ruských odborníků.

Alexej Miller a Fjodor Lukajnov před rokem publikovali analýzu Detechment Instead of Confrontation: Post-European Russia in Search of Self Sufficiency, v níž se věnují ruskému místu v Evropě, respektive ve světě, v němž dominuje Západ. Uvedli, že rok 2016 předznamenal konec sedmdesátiletého vývoje systému mezinárodních vztahů, který se skládal ze dvou období: ze studené války, která zahrnula 40. - 80. léta minulého století a období přechodu, vyvolané rozpadem SSSR. Z hlediska našeho tématu považují pro Rusko v období přechodu za zásadní (crucial), že Západ existoval jako jediný (akceptovatelný) politický koncept. Tvrdí, že to vlastně byl tlak SSSR, který způsobil, že se Západ proměnil z klubka svářících se mocností do podoby soudržné ideologické, politické, vojenské a hospodářské komunity. Ta se po rozpadu SSSR nezhroutila, ale přetrvala a postavila Rusko před dvojí nepř́ijemné dilema. První je trvale přítomné minimálně dvě stě let a týká se (ne)přijetí západní ideologie a hodnot. Druhé se týkalo přijetí/odmítnutí participace na Západem vytvořených a kontrolovaných politických institucí. Rusko nemělo jinou šanci, než nově definovat svou pozici vůči Západu jak z hlediska vnitřního/ hodnotového, tak i mezinárodního/strukturálního. Oba autoři následně tvrdí, že Rusko se s těmito dilematy, respektive odpovědí, kterou Západu poskytlo, nikdy neztotožnilo a uvádějí, že tento problém v roce 2014 velmi správně identifkovali Ivan Krastev a Mark Leonard, kteří konstatovali, že: „Evropané zaměnili ruskou neschopnost vzdorovat vzniku

22 ROJEK, P. Rusko: prokletí impéria. Zdroje ruského politického chování. Brno: CDK, 63.

23 ŠEDIVÝ, J. Koncepce rovnováhy moci ve 20. století. Mezinárodní vztahy č. 2/1998. Vol. 33, 68.

24

MEARSHEIMER, J. The Tragedy of Great Power Politics. Chicago: W. W. Norton and Co., s. 2. 
post studenoválečného řádu za souhlas. Chybně považovali slabost za [mentální] obrat (conversion). “25

\section{POZNÁMKA ZÁVĚREM}

Domnívám se, že z výše uvedeného je možné učinit závěr, že ruské elity, jakkoli po nezanedbatelně dlouhou dobu (přinejmenším do roku 2000, ale spíše do „slavné“ Putinovy řeči v Mnichově roku 2007) oficiálně a veřejně přebíraly západní hegemonistický diskurs, se ve skutečnosti nikdy neztotožnily se základními hodnotovými parametry at již demokratického státu, nebo tržní ekonomiky. Bez ohledu na to, co všechno by Západ (ne)učinil, pokud jde o rozšíření/expanze EU nebo NATO, byla by ruská reakce, dříve či později, odmítavá, respektive by sledovala cíl posílení/obnovy vlastního mocenského postavení. $\checkmark$ tomto světle, a vzhledem ke geografické blízkosti je proto jak pro ČR, tak pro všechny ostatní někdejší socialistické či svazové státy vstup do EU/NATO pozitivem a bezpečnostní zárukou. A pokud neorealisté chtějí psát o světě takovém, jaký je, a ne o světě, který by chtěli mít, tak by něco takového, jako je ruský „zdravý rozum“ neměli ponechat stranou.

Poznámka: Texty byl pro zlepšení přehlednosti redakcí rozděl a opatřen nadpisy.

Autor: $\quad$ PhDr. Michael Romancov, Ph.D. Narozen 1969 v Praze. Politický geograf UK FSV Praha a Metropolitiní univerzita Praha, pedagog a publicista. Pưsobí na katedře politologie Institutu politologických studií FSV UK a na Metropolitní univerzitě Praha. Přispívá do řady českých periodik. Je absolventem Pedagogické fakulty, Filozofické fakulty a Fakulty sociálních věd UK. Z odborného hlediska se zaměřuje na politickou geografii, geopolitiku a Rusko.

Jak citovat: ROMANCOV, Michael. K polemice Luboše Dobrovského s Janem Eichlerem. Vojenské rozhledy. 2017, 26 (3), 91-98. ISSN 1210-3292 (print), 2336-2995 (on-line). Available at: www.vojenskerozhledy.cz

25 MILLER, A.; LUKYANOV, F. Detachement Instead of Confrontation: Post-European Russia in Search of SelfSufficiency. Dostupné z: http://www.kreisky-forum.org/dataall/Report_Post-EuropeanRussia.pdf 
Vybíráme z archivu

I v tomto vydání časopisu zveřejňujeme článek, který je z pohledu historie velmi zajímavý. Byl publikován ve Vojenských rozhledech v roce 1935 (Všeobecná část), v 11. a 12. čísle (dostupné z http://vojenskerozhledy.cz/archiv-menu-search/rocniky-1920-1944/ rocnik-1935). Přestože zde autor publikuje svoje vlastní názory, a to patrně bez hlubších analýz, článek zřejmě odráží většinový názor na zásadní otázky bezpečnosti předválečného Československa. My dnes víme, jak se historie vyvíjela. Některé předpoklady se tragicky naplnily, některé bohudík ne a některé byly liché a znamenaly marně vynaložené úsilí. Při hlubším zamyšlení Ize v následujícím textu nalézt řadu podnětů k zamýšlení nad současným bezpečnostním vývojem. Tyto paralely jsou $v$ některých prípadech až zarážející. Posud'te sami.

Redakce

\section{Předpoklady přišti války.}

\section{Major gšt. Jiří Sommer}

Vojenská věda je proti jiným ve velké nevýhodě: může se provozovat v míru jen teoreticky. Mírové teorie vyzkoušejí se až ve válce. To je již ovšem pozdě. Válka není pokusnou školou, ale zápasem o bytí a nebytí národa. Do utkání má armáda již prijít s hotovou, jednotnou a vítěznou doktrínou. Proto musí voják v míru pečlivě uvažovat o možnostech a charakteru príšti války a činiti z toho praktické závěry. Několik pouček do budoucna můžeme již odvoditi z průběhu světové války.

\section{Potřeba prípravy mobilizace válečného průmyslu.}

O trvání válečného konfliktu byly i v odborných vojenských kruzích růžové představy. Do vánoc 1914 mělo býti vše odbyto.

Vzhledem k tomu spoléhaly se generální štáby, že mírové zásoby zbraní, střeliva a jiného válečného materiálu na krátké polní tažení úplně vystačí. Nebyly proto učiněny téměř žádné prípravy pro mobilizaci válečného průmyslu.

Jak vypadala situace měsíc po zahájení operací? Vyslechněme hlášení francouzského generalissima ministerstvu války z 15. zárí 1914.

„Armády spotřebovaly polovinu zásob dělostřeleckého střeliva. Bude-li spotřeba takto pokračovati, jsme za šest neděl na holičkách. Nařizuji útvarům nejúzkostlivějši šetření střelivem. Přesto je si třeba uvědomit: bud'výroba dělostřeleckého střeliva značně vzroste, nebo nebudeme moci od 1. listopadu pokračovat ve válce."

Podobná situace byla i v Německu a ostatních válčícich státech. Němcům nedostávalo se koncem roku 1914200000 pušek. Rakušané mohli poslat v květnu 1915 na italskou frontu jen stará děla, děla ukořistěná v Rusku a děla námořní. 
Tento všeobecný nedostatek materiálu donutil válčíi strany, aby se zakopaly do země a šetřily střelivem. Útok na zakopaného protivníka vyžaduje velké spotřeby střeliva: útoku třeba se proto zříci, dochází k stabilizaci front a tím dlouhému trvání války. Byla to především nepřipravenost $v$ otázkách materiálních, která vedla $k$ dlouhotrvající válce.

\section{Mobilizaci válečného průmyslu umožní mírové zásoby.}

Nesmíme zase precházet do druhého extrému, tj. pripravit si po hotovost válečného průmyslu a upustit od větších mírových zásob materiálu.

Při preměně mírového průmyslu na válečnou výrobu musíme vzíti v úvahu především potřebné úpravy strojü, etablování nových strojů, zajištění pracovních sil, získání specialistů, zajištěni surovin a rušení všech těchto príprav nepřátelským letectvem, sabotáží apod.

\section{To vše vyžaduje času, což se v míru často přehlíží.}

$\checkmark$ této př́čině jsou poučné zkušenosti USA. Americký válečný průmysl při vstupu Ameriky do války (r. 1917) byl již v chodu: dodával již před tím spojencům válečný materiál. A přece až do príměřís se na frontě neobjevilo ani jediné americké dělo, ani jediný americký tank. Zde byla Amerika úplně odkázána na spojence. Přes své nevyčerpatelné zdroje nebyla Amerika ani po půldruhém roce války hotova s mobilizací svého válečného průmyslu!

I když můžeme dnes počítat s lepši organizaci, přece úplná mobilizace válečného průmyslu potrvá alespoň rok. Doba potřebná pro mobilizaci válečného průmyslu je pro obranu státu nebezpečná. Nebezpeči nekončí v okamžiku, kdy vyjde z továrny první vyrobený granát (motor atd.), tímto okamžikem se nebezpeči jen počíná mírnit, ale trvá až do doby, kdy výroba stačí uhradit válečnou potrebu.

Dostatečné mírové zásoby a príprava průmyslové mobilizace se vzájemně doplňuji: zásoby dovolí nám začiti válku, mobilizace v ní pokračovati.

\section{Rozvojem materiálu neušetříme na lidech.}

Materiál, dělo, kulomet, letoun, tank atd. nabývá bojové hodnoty teprve v rukou člověka. Často se tvrdí, že rozvoj materiálu ušetři nám lidi, že vystačíme s menší armádou dokonale technicky vybavenou. Tank nebo letoun nám prece vykoná práci za velký počet bojovníků primitivně ozbrojených. To je jen relativní pravda.

Tank je v boji obsloužen 13 muži. Bitevní letoun rovněž. Můžeme předpokládat, že jeden samostatný prapor v síle asi 1000 mužü nahradí nám, řekněme, 20 tanků a 20 letounů s obsluhou asi 100 mužů. S desetinou počtu tedy dokážeme totéž co prapor, ba více, jelikož dosáhneme větší rychlosti a tím i větší možnosti manévru.

Tento výpočet je jen zdánlivě správný: co ušetříme $v$ bojovém sledu, je rozloženo do hloubky k udržováni a zásobování strojů. Tank, který vedou do boje 2 muži, potřebuje asi 20 mužů k své službě. Podobně letoun. (Opravy, udržování, zásobování, letiště apod.). Sebevýkonnějším materiálem neušetríme tedy na lidech, nýbrž je jen rozložíme do hloubky.

\section{Význam převahy počt ů zůstává.}

Za války je v převaze vždy početnější protivník za předpokladu stejné bojové výbavy. Přičina ústupu za války byla vždy sváděna na početnějšího nepřitele. V roce 1914 početní 
převaha Němců na západním bojišti překvapila Francouze a málem vedla k jejich porážce. Jen početní prevahou nakonec spojenci vyhráli válku.

Počty budou hrát v každé evropské válce důležitou roli. Nemusí se k nim přihližet snad jen $v$ koloniích, $v$ bojích s primitivně ozbrojenými divochy.

\section{Potřeba všeobecné branné povinnosti a přiměřeně dlouhé presenční služby.}

Armáda se nedá za války improvizovat. Tu jsou zajímavé zkušenosti v improvizaci velkých armád v Anglii a Americe, kteréžto země, jak víme, měly v míru jen malé námezdné armády.

Již 7. srpna 1914 povolil anglický parlament Kitschenerovi rozmnožení radové armády o 500000 mužů. Těchto 500000 mužủ prihlásilo se nadšeně pod prapory do počátku zárí. Byli hned zařazeni do nově se tvořicích divizí. A prece teprve v létě 1915 , tedy po roce, opouštěly první Kitschenerovy divize Anglii.

Při dlouho trvající válce nadšení z Angličanů vyprchalo. Již v létě 1915 nedostávalo se dobrovolníků $k$ doplňování armády přes velkou a nákladnou propagandu a silný tlak veřejného mínění. Nezbylo než uzákonění všeobecné branné povinnosti (v lednu 1916).

Amerika po vstupu do války (duben 1917) prikročila - jistě pod dojmem anglických zkušeností - ihned k zavedení všeobecné branné povinnosti, ačkoli ve 120milionové ř́ši nebyl nedostatek lidského materiálu. Pruní divize nové národní armády byly vytvořeny v řijnu 1917. Tyto divize převážely se do Evropy až v létě 1918, do bojů zasáhly, a to ještě po delším výcviku ve Franci, až na podzim 1918.

Čas, který Anglie a Amerika měly k disposici k vytvoření armády, nebude mít v príští válce žádný stát. Potřeba velké armády je právě nejakutnější v okamžiku vypuknutí válečného konfliktu. Postavit národní armádu v prvních dnech války je možno, disponujeme-li početnými a vycvičenými zálohami. Tyto dovede vytvořit jen delší presenční služba při všeobecné branné povinnosti.

Miliční systém, na který se rádi u nás někteří odvolávají, nemůže a nedovede v době několika neděl povinných cvičení vytvořit moderního bojovníka. Sám velitel švýcarské armády generál Wille v roce 1914, kdy vojsko mělo čelit již nepríteli, měl obavy o bojovou hodnotu své armády: vyjádřil se tehdy, že vojsko potřebuje před použitím ještě delšího výcviku.

\section{Potřeba značných velitelských kádrů.}

Za války nejsou nám nic platné vycvičené zálohy, nemáme-li pro ně velitelské kádry. Neorganizované masy tvoři jen stádo - ne armádu.

$\checkmark$ Anglii v roce 1914 odešli téměř všichni důstojnici a poddůstojníci s aktivními divizemi do Francie. Pro nově se tvoříci Kitchenerovy divize nebylo velitelů a cvičitelů, ač jejich potřeba byla okamžitá. Byli proto povoláni důstojníci z fronty, absolventi krátkých důstojnických kursů jmenováni prímo kapitány a poddůstojníci jmenováni podle obličeje.

Američané měli při tvoření své národní armády takové nedostatky cvičitelů, že u speciálních zbraní zastávali tato místa civilní odbornici. Spojovací sít za frontou obsluhovaly často ženy. Speciální útvary zbraní a služeb nepodařilo se Američanům postavit ani do konce války. Modernímu vedení války učili se američti důstojníci v kursech u spojenců ve Francii.

Mírová armáda musí proto míti značnou zásobu velitelü, hlavně vyšších. Ty nelze armádě vyměřovat podle úzkého rámce mírové organizace, jak to s oblibou činí naše večerníky, na kolik mírových vojáků prijde jeden generál nebo jedna „šarže“. 
Pro důležitější velitelská místa nelze též počítat se záložními důstojníky s poukazem, že za války veleli rotám. Ano, veleli praporům, ale po delši praxi na frontě. Schopní a zkušení vyšši velitelé nedají se stvořiti v několika měsících, ale v desítiletích. Jen vycvičené a organizované zálohy jsou s to užíti mírových zásob a materiálu vyrobeného za války.

Válka se vyhrává jen na cizím území.

Tomuto tvrzení by vlastně odporoval výsledek světové války, kterou dohoda vyhrála, ačkoli německá a rakouská vojka stála při zakončení války hluboko na jejím území. Jen zdánlivě.

Bilance války dělá se až v míru a její výsledek je pro spojence smutný. Německo nenahradilo nikdy a již také nenahradí škody, které válka zpưsobila na bojištích v západní Francii.

$\checkmark$ príšti válce bude snahou obou válčicich stran přenésti boj ihned na neprátelské území. Tím získává útočník nejen morální převahu a zástavu pro budoucnost, ale i cenné operační a materiální výhody: ztiží mobilizaci a nástup protivníka, chrání lépe vlastní území, získává nové zdroje. A pak operace se provádějí lépe na cizím území; z cizího krev ne teče. Pochybuji, že by Němci v roce 1917 před ústupem na "Siegfried-stellung" byli provedli tak vědecky dokonalé ničení, kdyby šlo o jejich území.

Přenést válku do země protivníka bude úkolem motomechanizovaných (rychlých) vyšších jednotek, složených z aktivního personálu a stále - i v míru - připravených $k$ akci. Čelit jím dovedou jen permanentní opevnění a vlastni rychlé vyšší jednotky.

\section{Permanentní opevnění neztratilo svůj význam.}

Je všeobecně rozšíren názor, že stálá opevnění za světové války zklamala. A přece byla to stálá - a poměrně zastaralá - opevnění, která donutila Němce k manévru prèes Belgii. Ten stál Němce čas i vítězství.

Od permanentního opevnění nemůžeme žádat, aby rozhodlo válku. Jeho účelem je jen zadržet a zpomalit postup nepřitele a tak získat čas $k$ dokončení vlastních príprav nebo vytvorit príznivou situaci pro manévr.

Stálé opevnění je zvláště důležité pro stát, jehož území nemá hloubky, kde i malá ztráta území znamená nebezpečnou ztrátu materiálních zdrojů. Permanentní opevnění dovoluje šetřit silami v krytu hranic ve prospěch polní armády. Jen v tomto prípadě nám materiál šetři lidi.

\section{H o s p odářs ká b lokáda.}

Vítězství spojeneckým zbraním přinesla - ne v poslední řadě - též hospodářská blokáda ústředních mocností. Ani ne tak dlouho trvající válka jako několikaleté nedostatečné zásobování rozvrátily rakouskou armádu.

Čím slabší je hospodářská pozice státu, tím důkladnější a dalekosáhlejší opatření třeba v míru učinit pro případ, že by stát byl odkázán sám na sebe.

\section{Propaganda.}

Zhroucení ruské armády v roce 1917 bylo hlavně dilem organizované a soustavně provozované propagandy a šírení válečných zpráv centrálními mocnostmi.

Rozšiřením rádia je propagační činnost velmi ulehčena. Čelit jí přiměřenými prostředky je obzvláště důležité u států s národnostními menšinami, jichž část bude vždycky tíhnout za hranice. Ne nadarmo zřizují se dnes ministerstva propagandy.

Vítězství lze získat jen při krátkém válečném tažení. 
Světovou válku sice formálně vyhrála jedna strana, ve skutečnosti skončila však válka - po dlouhých 4 letech - remízou, oboustranným vyčerpáním. Poražený nesplnil-a snad ani nemohl-hospodářské podmínky míru.

$O$ vítězství může být řeč jen při krátkém válečném tažení, po kterém je poražený ještě schopen splnit hospodářské podmínky míru a vítěz je s to ho $k$ tomu donutit.

Nyni, když jsme nasbírali určité poučky z poslední války, zajímá nás otázka, jaká bude príští válka?

\section{Předpoklady príští války. Počátek války.}

Mezinárodní morálka světovou válkou poklesla. Všecky drobné války a válečné akce vedené po světové válce začaly bez formálního vypovědění války. Válči se stále, ač všecky státy podepsaly pomalu desítky protiválečných paktů a války se žrekly. Sankce Společnosti národů proti útočníku se neuplatňuji, a když, tak jen proti slabým.

Žádný pakt nás před válkou neochrání. Vývoj spěje $k$ stavu ·před světovou válkou - $k$ aliancím. Spojence najde jen ten stát, který má zdatnou armádu. Ale ani hodnotu spojenců nelze preceňovat; smlouvy se v daný okamžik neplní podle ducha smlouvy, ale podle toho, jsou-li pro smluvní strany ještě výhodné. Jen pro dané slovo neobětuje dnes žádný stát ani jednoho vojáka. To je třeba mít stále na mysli: spoléhat na sebe víc než na všecky spojence dohromady. Dnes existuje jen spojenectví zájmů, ne citu. A národní zájem se rychle mění.

$\checkmark$ budoucnosti při politickém napětí nesmíme čekat na formální vypovědění války. Nesmíme se dát útokem překvapit. Musíme aspoň pro počátek počitat, že budeme odkázáni sami na sebe. Musíme být proto stále na stráži!

\section{Pře pad válkou.}

Dejme si následující predpoklad: Vláda určitého státu není spokojena se statutem quo. Ví přesně, že se nedá změnit jinak než silou. Určí si tedy dobu řekněme tři let k prípravě zamýšlené válečné akce.

$V$ této době si doplní mírové zásoby, zmodernizuje mírovou výzbroj armády (nejlepši a nejmodernější vzory zbraní), připraví si mobilizaci válečného průmyslu; zajistí si potřebné suroviny, umistí v továrnách stroje, zapracuje odborný personál atd.

Jeden až dva měsíce pred určenou Ihůtou zahájí válečnou výrobu. Započetí válečné výroby neujde ovšem pozornosti sousedů. Ohrožený stát podnikne diplomatické kroky, akci ke Společnosti národů. Začne zdlouhavé mezinárodní vyjednávání, kterým útočník získává jen další čas.

Obět útočníka je ve velké nevýhodě. Z finančních důvodů nemůže mít mírovou výzbroj a nejmodernějši mírové zásoby, děla, letouny a tanky posledních vzorü. Průmyslovou mobilizaci zahájí daleko později.

Útočník, který by tajně připravil válku, měl by od počátku výhodu nejen lepší výzbroje, ale i rychlejši dodávky válečného materiálu. Výhody toho druhu se dají dnes vyvážit jen nadlidským úsilím a krvavými obět'mi.

Tyto vyhlídky jsou lákavé pro národy bez skrupulí, odhodlané k válce. Rozhlédneme-li se Evropou, najdeme takových národů hned několik, a to v situaci, která není nepodobna našemu předpokladu.

Pro nás je nebezpečnějši přepad tajně připravenou válkou než útok sice s překvapením, ale materiálně nepřipravený. Proto je třeba po té stránce možné protivníky dobře střežit. 


\section{Preventivní válka.}

Obrana proti prepadu válkou je toliko v preventivní válce. To znamená: prepadnout protivníka dř́ve, než bude se svými prípravami hotov. Posoudit ovšem, kdo připravuje přepad válkou a kdo preventivní válkou, bude velmi obtižné. Každý stát bude o sobě tvrdit, že pripravuje preventivní válku - proti přepadu válkou, který chystá soused.

Rakousko-Uhersko tvrdilo, že tažení do Srbska 1914 je preventivní válkou. Totéž tvrdí dnes Itálie o tažení do Habeše.

Poněvadž válečné prípravy nelze dnes utajit - je sta cest, jak je lze i bez špionáže bezpečně zjistit - začínají závody ve zbrojení, které jsou předchůdcem války.

\section{Vzdušná válka?}

Teorie vzdušné války pochází z Itálie. Souvisí to s Její zeměpisnou polohou. Pozemní italské hranice tvoři většinou těžký horský terén, kde šest měsíců v roce je zima. Proniknutí horskými soutěskami je pro moderni armádu v létě těžké, v zimě nemožné.

Vznikajícího nepřitele Ize zadržovat poměrně slabými pozemními silami; v soutěskách Ize jej ničit letectvem, protože nemůže nikam vyhnout, ani se rozvinout.

Jádro italského průmyslu leží v severní Italii a té může neprátelské letectvo snadno dosáhnout.

$Z$ těchto dưvodu čeká Itálie rozhodnutí válečného konfliktu spíše ve vzduchu než v dobrodružné ofenzivě v horách. Proto má též Italie organisováno letectvo jako samostatné vojsko vedle pozemní armády a námořnictva.

Zvláštní italské poměry neplati pro nás. Je jisté, že letectvo bude mít v přiští válce důležitou úlohu, hlavně na jejím počátku. Letectvo zpưsobí, že válka od prvního okamžiku půjde na nůž. Učinilo-li letectvo od války obrovské pokroky, platí totéž o obraně proti letadlům, která po válce nespala a je rovněž na výši. Teprve válka ukáže, kdo s koho.

Válka se vedla vždycky na důležitých dopravních cestách at' už na zemi, nebo na moři. K válce vzdušné by mohlo dojít, až gros transportu půjde vzduchem, a k tomu je ještě daleko.

\section{Válka motorů?}

Tvrzení, že válku rozhodne v budoucnosti motor, mohlo vzniknout jen v Anglii. Anglie je bohatá země s rozsáhlým těžkým průmyslem. Ta by si nejsnáze mohla dovolit vybavit každého bojovníka tankem.

Podle této teorie je nechráněný pěšák na moderním bojišti nemožný. Tím spíše jezdec. Válku má rozhodnout motomechanizovaná armáda složená z tanků, motorizovaných děl a motorizované pěchoty, která ovšem bude mít jen policejní úlohu: obsazovat dobyté území.

Slabiny této teorie jsou zřejmé: Co si počne motomechanizovaná armáda v lese, $v$ horách, v zimě, na jaře a na podzim v rozmoklém terénu, kdy ani jeden tank nezabere? Co zbude z této armády, nebude-li náhodou fungovat zásobování pohonnými hmotami? Pěšák a jezdec dovede žít z kraje a bojovat i o hladu, ale motor žádná morální domluva neprivede k tomu, aby udělal jen krok bez benzínu.

Motomechanizovaných armád se v dohledné době nemusíme obávat, spiše motomechanizovaných vyšších jednotek, které by operovaly v rámci pozemni armády. Tyto jednotky, nasazené v pravý čas a v citlivém směru, mohou přivést rozhodnutí v bitvě. Uplatní se zvláště na počátku války prí nájezdech k rušení protivníkovy mobilizace nebo k zajištění operační základny na nepřátelském území. 


\section{Bakteriová válka?}

Podstata bakteriové války spočivá $v$ umělém šírení epidemie v neprátelském vojsku nebo kraji. Zdá se, že tento zpưsob válčení nemá vyhlídek na úspěch; proti většině bakterií máme dnes spolehlivou ochranu, ostatní zárodky by byly dvojsečnou zbrani.

Účinnost všech bojových prostředků záleži hlavně na momentu překvapení. Naděje, že by se podařilo najít novou sdělnou chorobu a udržet ji v tajnosti, jsou nepatrné.

Ke vzniku epidemie nestačí jen existence bakterii; je ještě třeba, aby zárodek byl vpraven do těla přislušnou cestou. Mnohé nemoci lze přenášet jen prímým stykem. Balit zárodky do střel (leteckých pum) není možné, byly by zničeny teplem, které se vyvine prí explosi. Rozprašování bakterií z letadla by bylo možné jen v malé výšce, a to je pro letoun velmi nebezpečné. Agenti mohou zamořit jen některá místa a při tom jsou sami nejvíce ohroženi.

Nepochybuji o tom, že $v$ príští válce dojde $k$ pokusưm o bakteriovou válku Ize však očekávat, že při řádných profylaktických a hygienických opatřeních tyto pokusy budou bez vlivu na výsledek války.

\section{Plynová válka.}

Boj plynem v priští válce nebude novinkou. Známe jeho formy již ze světové války. Je jisto, že bude dokonalejší: zatím byly vynalezeny účinnější bojové látky.

Boj plynem je ovšem omezen počasím. $V$ našich krajinách, kde věčně fouká a často prší, najde se sotva 50 dní v roce, kdy Ize plynu s výhodou použít. V pohybné válce na užití plynu ve větších rozměrech není čas. Plyn zůstane proto i nadále zbraní spíše přiležitostnou než pravidelnou, a to už proto, že jeho účinek je zaručen jen proti živým nechráněným cílum. Dobré ochranné prostředky pro osoby a zvírata jsou ovšem podmínkou úspěšného boje proti plynu.

\section{Pohybná válka či stabilizace?}

Rychlého vítězství lze dosíci jen pohybnou válkou. Přes pokroky motorizace a mechanizace $v$ armádách nelze $v$ príští válce vyloučit možnost ustálení front tam, kde se utkaji velké sily na poměrně malém prostoru - např. na bojišti německo-francouzském anebo francouzsko-italském.

$V$ našich poměrech, kdy naše armáda může válčit na frontě velmi široké, je jakákoli stabilizace nemožná.

\section{Z á v ě r.}

Způsob boje se nezměnil v své podstatě od pravěku. Boj na dálku byl vždy veden vrháním střel. Do vynalezení střelného prachu vrhal člověk střely (šípy, kamenné koule) lukem anebo různými př́stroji. Po vynalezení střelného prachu nastoupily na místo luků a praků pušky a děla, později i samočinné zbraně. Takový byl též ráz boje ve světové válce. $\checkmark$ př́šti válce budou opět vrhány strely, které zabijeji samy nebo obsahuji bojové plyny, zápalné látky i choroboplodné zárodky. Revoluce ve válčení nastane, až věda vynalezne způsob, jak ovládat elektřinu nebo jinou sílu, která by dovolila na libovolnou vzdálenost zabijet lidi, ničit stroje atd. V takové válce by se mohlo utkat i Švýcarsko s Japonskem. Pro takovou válku tajemných paprsků ovšem vývody, které jsme zde učinili, platit nebudou.

Zatím nejsme tak daleko. Od světové války se válčí ve světě s malými přestávkami nepretržitě. A prece jsme neslyšeli, že by některý stát použil nějakých záhadných zbraní a tím 
si zajistil rychlé vítězství. Platí to i o velmocích: Francie dvě léta zápasila s Abd al-Karímem, Japonsko stálo mnoho obětí, než zdolalo Číñany u Šanghaje, Itálie jen velmi zvolna proniká do Habeše. A pritom válčici velmoci nikdy nenarazily na stejně hodnotného protivníka!

Přišti válka bude válkou materiálu. Musíme počítat s tím, že se protivník tajně na válku připraví a přepadne nás, aby v krátkém válečném tažení rozhodl válku na našem území $v$ svůj prospěch.

Čelit přepadu mohou jedině stálá opevnění hranic a rychlé jednotky. Začít válku umožni nám mírové zásoby, pokračovat v ní-mobilizace válečného průmyslu, vyhrát ji-moderně vyzbrojená, dobře vycvičená a vedená početná armáda. 



\section{OBSAH}

Vliv Ruska na dynamiku konfliktu v Náhorním Karabachu

Pavlína Bláhová

Energetika jako strategický nástroj hnutí Hizballáh v konfrontaci s Izraelem

Lukáš Tichý

Aktuální úkoly kybernetické obrany rezortu Ministerstva obrany

Miroslav Feix, Dalibor Procházka

Výsledky výzkumu k problematice ženijní podpory pohybu v bojových operacích

Ota Rolenec, Jan Kyjovský, Jaroslav Zelený, Tibor Palasiewicz

\section{PŘíLOHA}

Česká republika a „nová“ Společná bezpečností a obranná politika EU: Čas zásadních rozhodnutí.

Vilém Kolín

Společné financování NATO - včera, dnes a zítra

Josef Múčka

K polemice Luboše Dobrovského s Janem Eichlerem

Michael Romancov

Předpoklady příští války. 


\section{CONTENTS}

Russia's Influence on the Conflict Dynamics in Nagorno Karabakh

Pavlína Bláhová

Energy as a Strategic Tool of Hezbollah Movement in Confrontation with Israel

Lukáš Tichý

Recent Objectives of Cyber Defence in the Department of Defence

Miroslav Feix, Dalibor Procházka

Results of Research to the Issue of Engineer Support in Combat Operations

Ota Rolenec, Jan Kyjovský, Jaroslav Zelený, Tibor Palasiewicz

\section{ENCLOSURE}

The Czech Republic and „New“ EU Common Security and Defense Policy: Time of Crucial Decisions.

Vilém Kolín

NATO Common Funding - Yesterday, Today and Tomorrow

Josef Múčka

Commentary on Luboš Dobrovský's Controversy with Jan Eichler

Michael Romancov

Předpoklady příští války. 


\section{Časopis VOJENSKÉ ROZHLEDY}

čtvrtletník

Vydává:

Ministerstvo obrany České republiky, Tychonova 1, 16001 Praha 6 - Dejvice

Vydávající instituce:

Univerzita obrany, Kounicova 156/65, 66210 Brno

IČo: 60162694

Vojenské rozhledy č. 3/2017

Ročník: XXVI. (LVIII.)

Datum předání do tisku: 4. 9. 2017

Rozšiřuje:

OKP MO, distribuce, Rooseveltova 23, 16105 Praha 6

Olga Endlová, tel. 973215 563, endlovao@army.cz

\section{Redakce:}

Mgr. Martin Doleček, telefon: 973442588

E-mail: vojenskerozhledy@unob.cz

\section{Redakční rada:}

Ing. Vojtěch Němeček, Ph.D. (předseda), PhDr. Miloš Balabán, Ph.D., doc. Mgr. Oldřich Bureš, M.A., Ph.D., doc. PhDr. Felix Černoch, CSc., Luboš Dobrovský, Mgr. Lukáš Dyčka, doc. PhDr. Jan Eichler, CSc., Ing. Jiří Halaška, Ph.D., plk. doc. Ing. Vladan Holcner, Ph.D., Ing. Karel Janáč, prof. Ing. Aleš Komár, CSc., PhDr. Tomáš Kopečný, brig. gen. Ladislav Košner, CSc., Mgr. Josef Kraus, Ph.D., plk. Ing. Tomáś Novotný, Ph.D. MSc., Mgr. Martin Riegl, Ph.D., Ing. Ján Spišák, Ph.D., RNDr. Pavel Štalmach MBA, Mgr. et Mgr. Lukáš Tichý, Ph.D.

\section{Tajemník redakční rady:}

Ing. Vladimír Karaffa, CSc.

Sídlo redakce: Kounicova 65, 66210 Brno

Adresa pro zasílání pošty:

Vojenské rozhledy - redakce, Kounicova 156/65, 66210 Brno

Časopis Vojenské rozhledy v elektronické podobě naleznete na:

http://www.vojenskerozhledy.cz/

\section{Časopis je evidován:}

- v evropské databázi ERIH PLUS,

- v seznamu recenzovaných neimpaktovaných periodik vydávaných v České republice

- v mezinárodní databázi Index Copernicus Journals Master List 2015

- v katalogu Národní knihovny České republiky

- v databázi Central and Eastern European Online Library GmbH (CEEOL)

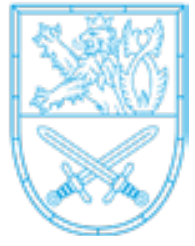

Grafická úprava: Adéla Zemanová

Tiskne: VGHMÚř Dobruška

Evidenční číslo: MK ČR E 6059

Identifikační číslo: ISSN 1210-3292 (print), ISSN 2336-2995 (on-line)

doi: $10.3849 / 2336-2995$ 




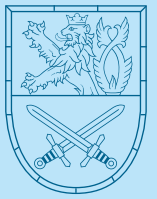

